\title{
Communist China's Policy Toward Laos: A Case Study, 1954-67
}

\section{Chae-Jin Lee}

\author{
International Studies, East Asian Series
}

Research Publication, Number Six

Center for East Asian Studies

The University OF Kansas 


\section{Communist China's Policy Toward Laos: A Case Study, 1954-67}

\section{Chae-Jin Lee}

International Studies, East Asian Series

Research Publication, Number Six

Center for East Asian Studies

The University of Kansas 
Copyright (C) 1970

Cfinter for East Asian Studies

The University OF Kansas

Library of Congress catalog card number 75-630107 All rights reserved

Manufactured in the United States of America

Sole distributors in the USA \& Canada

Paragon Book Gallery, Ltd.

14 East 38th Street

New York, N.Y. 10016 


\section{Acknowledgments}

The main portions of this study have been conducted over several years first at the University of California (Los Angeles) and then at the University of Kansas. In the process of gathering and analyzing the relevant materials, I have been truly indebted to a number of scholars and friends at both Universities. Above all, I owe a substantial intellectual debt to Professor H. Arthur Steiner whose correct inspiration and profound scholarship enriched my judgments on many difficult questions. At the early stage of this study I was very fortunate to receive valuable guidance from Professors Hans Baerwald, William P. Gerberding, David P. Mozingo, and Charles R. Nixon.

I would also like to acknowledge the continuous encouragement of Professors Grant K. Goodman and Felix Moos and the kind cooperation of Professor Thomas R. Smith who helped arrange my visit to Laos during the fall of 1967. Sincere appreciation is expressed to Professor Paul F. Langer of the RAND Corporation who read the entire manuscript and gave me extremely useful comments and suggestions. Finally, my special thanks are due my wife for her patient and devoted assistance.

Chae-Jin Lee

Lawrence, Kansas

January, 1970 


\section{Table of Contents}

PAGE

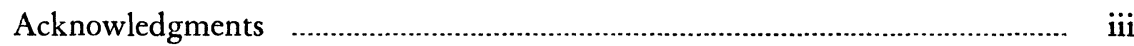

Introduction

I The Chinese Communist Conception of Laos ....................................... 1

II The Chinese Policy of Peaceful Coexistence ........................................... 13

Section One: China and the First Geneva Formula on Laos ................... 13

Section Two: The Bandung "Spirit" and Sino-Laotian Relations ........... 24

Section Three: Peking and the Peaceful Unification of Laos ................... 30

III The Chinese Policy of Assertive Pressure .............................................. 42

Section One: Collapse of the Policy of Peaceful Coexistence .................... 42

Section Two: Assertive Approaches toward Laos ..................................... 49

Section Three: The United Nations Presence and Its Effects .................. 57

IV The Chinese Policy of Negotiations at the Second Geneva Conference ...... 72

Section One: A Prelude to the Geneva Conference on Laos ...................... 72

Section Two: Chinese Positions and Tactics at Geneva ........................... 80

Section Three: Evaluation of the Second Geneva Formula ....................... 90

V The Chinese Policy of Reappraisal after the Geneva Conference ............... 97

Section One: Development of the Second Geneva Formula ...................... 97

Section Two: Gradual Erosion of a "Neutralized" Laos ............................. 103

Section Three: Reorientation of Chinese Policy in Laos ........................... 113

Section Four: Laos, the Vietnam War, and the Chinese Cultural Revolution .......................................................................................... 128

VI Evaluation and Implications …........................................................... 145

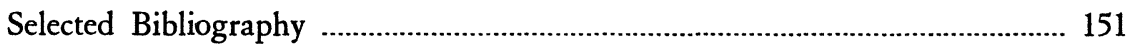

Index 


\section{List of Tables}

PAGE

1 Laos and Neighbors ...................................................................... $\mathrm{x}$

2 U.S. Foreign Aid to Laos, Fiscal Years 1955-57 ........................................ 35

3 Overseas Chinese in Indo-China: 1959-60 ......................................... 51

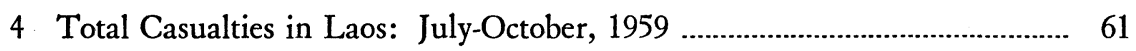

5 The International Commission: Status of Financial Contributions as of

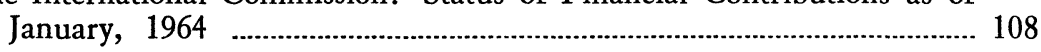

6 National Budget of Laos: FY 1964-67 .................................................. 132

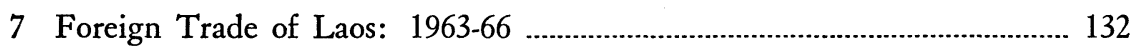

8 U.S. Economic Assistance to Laos: FY 1955-67 ........................................... 133

9 “Results" of Pathet Lao's Military Operations: 1966-67 ............................. 136

\section{Map}

Map of Indo-China ............................................................................. xii 


\section{Introduction}

The nature and direction of Communist China's foreign policy are inevitably intertwined with the particular political culture of the given country in which it is to be implemented. Conceivably, for the maximum realization of their policy goals, the Chinese decision-makers are likely to take into full consideration the major characteristics and various dimensions of Laos' political development, both domestic and external. In this brief introduction, I intend to identify some basic socio-economic conditions of Laos' heterogeneous political culture and to establish a broad conceptual backdrop against which a subsequent case study of Communist China's changing strategies and tactics toward Laos can be presented.

Among Communist China's Southeast Asian neighbors, the Kingdom of Laos-about the size of Oregon, with a population estimated somewhere between 2 and 2.8 millions-is the least developed and populated one. Its terrain is exceedingly mountainous, except that of the Mekong River valley, and its climate is tropical with two main seasons-a monsoon period (May-October) and a dry period (November-April). The combination of inaccessible mountains, thick jungles, and long monsoon season is naturally conducive to the conduct of a modern guerrilla warfare. Even a cursory survey of some selected statistics is sufficient to reveal the Kingdom's massive poverty: as of 1967, Laos' estimated annual per capita income was between $\$ 50$ and $\$ 67$; the ratio of total arable land was $7 \%$, the level of literacy $12 \%$, the number of modern doctors 10 , the length of total highways 3,600 miles, and the number of newspaper circulation 3 per 1,000 persons. ${ }^{1}$

More than $90 \%$ of the Laotian population are subsistence farmers, and perhaps half of them are ethnic Lao who speak Lao, believe in Theravada Buddhism, and live in the cities and along the Mekong River area. There are also Lao Theng (Kha and Khmu: 25\%), Lao Yung (Meo and Yao: 6\%), and other hill tribes who use mutually unintelligible languages and practice various forms of animism. As Professors Halpern and Kunstadter suggest, it is in the areas where the ethnic Lao are in the minority that the Pathet Lao have been most successful in creating their administrative structure parallel to that of the Royal Laotian Government. ${ }^{2}$ 
This diversity of ethnic, linguistic, and religious backgrounds, coupled with the virtual absence of modern mass communication media, makes national unity extremely difficult. It is questionable indeed whether Laos, even in the most favorable external circumstances, can constitute a viable and independent political system. Under the constitutional monarchy the King, who resides in the royal capital of Luang Prabang, reigns with the assistance of the 12-member King's Council, but he seldom rules the country. The Prime Minister, appointed by the King with the approval of the popularly elected National Assembly, leads the Council of Ministers at the administrative capital of Vientiane. Nevertheless a small group of French-educated aristocrats, bureaucrats, merchants, and military officers has effectively monopolized Laos' political life for many years. ${ }^{3}$

A considerable gap in social prestige and political orientation separates the urbanized elite from the populace in general. This separation is reinforced by weak national consciousness, poor communication systems, and lack of education in rural areas. The limitations on social mobility and political recruitment serve to perpetuate the elitist nature of Laos' political processes and to intensify the sense of alienation among ethnic minorities. The exclusive ruling group, however, is divided into competitive factions mainly along the lines of princely families and vague ideological inclinations. For the past two decades instability caused by factional struggles has marked Laos' politics. Political parties are also based upon personal loyalties and factional differences with the possible exception of the Neo Lao Haksat, a political wing of the Pathet Lao movement, which has attempted to transcend factionalism and to establish a mass party.

The long history of Laos is full of tragedies of internal strife and external aggression. An independent Laos was first set up in 1353, under the name of Lan Xang or Lan Ch'ang (Land of a Million Elephants). In the seventeenth century, however, it disintegrated into three principalities-Luang Prabang, Vientiane, and Champassak. Early historical experiences of Laos make it abundantly clear that the requirements for an independent and unified Laos are (1) the presence of an energetic and powerful ruler who can secure the allegiance of centrifugal social forces and (2) the existence of international checks and balances which can permit the political freedom of Laos. 
The expansion of French colonial power into Asia gradually brought these Lao principalities under its control in the later nineteenth century; first, France installed a vice-consulate at Luang Prabang after the 1885 agreement with Siam (Thailand), which had maintained de facto control over Laos since early nineteenth century; second, Laos became a French protectorate according to the 1893 FrancoSiamese treaty, which was concluded under the threat of French power. The French colonial policy, which was carried out by the Résident Superieur in Vientiane, did not recognize the economic and political potential of Laos, which consequently remained the least exploited country of Indo-China. Under this alien domination King Sisavang Vong of Luang Prabang could nominally unify the other principalities and provinces, but obviously without independent power of his own. ${ }^{4}$

During and after the Second World War Laos experienced a series of instances of foreign interference; Japanese invasion (March-August, 1945), Nationalist Chinese occupation (late 1945), and French reoccupation (1946). The resumed French colonial authority was immediately challenged politically and militarily by the Lao Issara (Free Laos) movement under the leadership of Princes (and brothers) Phetsarath, Souvanna Phouma, and Souphanouvong. The mounting pressures of nationalism and decolonization in post-war Asia compelled France to take measures for granting Laos its full independence and sovereignty: first, King Sisavang Vong obtained domestic political autonomy for Laos in August, 1946; second, he gained an independent status within the French Union in the General Franco-Laotian Convention of July, 1949. Satisfied with this French concession, the moderate Lao Issara leaders headed by Souvanna Phouma dissolved their government-in-exile in Bangkok in October, 1949, and returned to Vientiane one month later. But Prince Souphanouvong, inspired by $\mathrm{Ho} \mathrm{Chi}$ Minh's revolutionary ideals and assisted by Viet Minh cadres in Laos, refused to join the moderate nationalists; instead, he organized a "national resistance government" in August, 1950, and launched the Pathet Lao movement with the blessings of Vietnamese and Chinese Communists. Into these historical circumstances was injected the highly unsettling influence of the world-wide cold-war conflict.

The strategic and symbolic significance of Laos in cold-war politics 
stems mainly from the geopolitical fact that it shares a long and unstable borderline with six countries in the Southeast Asian Peninsula: 263 miles with China's southwestern province of Yunnan, 818 miles with North Vietnam, 277 miles with Cambodia, 146 miles with Burma, 301 miles with South Vietnam, and 1,090 miles with Thailand, including over 500 miles along the Mekong River. As its primary routes of access to the outside world are by way of Bangkok, Saigon, Hanoi, and Phnom Penh, Laos' very survival depends upon political developments in its immediate neighbors. The Sino-Laotian frontier, demarcated at the end of nineteenth century, runs through rugged mountains and forests where a number of uncontrolled ethnic minorities-such as Chinese-influenced Meo and Yao-straddle the boundary. Apropos of the frontier problem we may note that Liu Pei-hua's controversial Brief History of Modern China, published in Peking in 1952, included Laos, together with Vietnam, Cambodia, Burma, Malaya, and Korea, in the "Chinese territories taken by the imperialists in the Old Democratic Revolutionary Era (1840-1919)."

The geopolitical and strategic setting of Laos tends to generate problems of vital importance not only to its bordering states, but also to major world powers concerned with Southeast Asian affairs, especially the United States and the Soviet Union. The Kingdom of Laos is thus caught in the turbulent cross-currents of domestic and external political dynamics - the emergence of modern nationalism, the process of decolonization, the pressure of international Communism, the movement for neutralization, the recurrence of civil wars, and the reassertion of

TABLE 1

LAOS AND NEIGHBors ${ }^{a}$

\begin{tabular}{|c|c|c|c|}
\hline Country & $\begin{array}{l}\text { Population } \\
\text { (in } \\
\text { thousands) }\end{array}$ & $\begin{array}{l}\text { Total Land } \\
\text { Area } \\
\text { (sq. km.) }\end{array}$ & $\begin{array}{l}\text { Population } \\
\text { Density } \\
\text { (per sq. km.) }\end{array}$ \\
\hline Laos & 2,763 & 236,800 & 12 \\
\hline China & 720,000 & $9,561,000$ & 75 \\
\hline 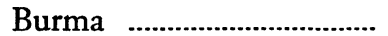 & 25,811 & 678,033 & 38 \\
\hline Cambodia & 6,415 & 181,035 & 35 \\
\hline 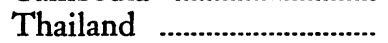 & 32,680 & 514,000 & 64 \\
\hline No. Vietnam & 20,100 & 158,750 & 127 \\
\hline 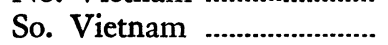 & 16,973 & 173,809 & 98 \\
\hline
\end{tabular}

a Source: United Nations Statistical Yearbook 1968 (New York: United Nations, 1968).

b Population figures are as of mid-1967. 
traditional interests of such neighbor countries as Vietnam, Thailand, and China. In order to help resolve some of these basic problems, major world powers have twice attempted to effect a negotiated settlement for Laos at the Geneva Conferences of 1954 and 1961-62. Efforts for Laos' international neutralization, however, have failed. Consequently, this weak and land-locked country still remains both a victim and an aggravating element in the protracted international conflict which is indeed one of the most representative cases of contemporary world politics.

\section{Notes}

1. See Fact Sheet (Vientiane: USAID/Laos, 1967), pp. 1-11, and Ebauche D'Une Comptabilité Nationale Lao: Comptes Economiques pour 1964 (Vientiane: Ministre du Plan et de la Cooperation, 1967), pp. 12, 23.

2. Joel Halpern and Peter Kunstadter, "Laos: Introduction," in Kunstadter (ed.), Southeast Asian Tribes, Minorities, and Nations, Vol. I (Princeton: Princeton University Press, 1967), pp. 233-258.

3. For discussions of Laos' general political problems, see Roger H. Smith, chapter on Laos, in George McT. Kahin (ed.), Governments and Politics of Southeast Asia (Ithaca: Cornell University Press, 1964), pp. 527-592; Stuart Simmonds, "Independence and Political Rivalry in Laos, 1945-61," in Saul Rose (ed), Politics in Southern Asia (London: Macmillan, 1963), pp. 164-199; Joel M. Halpern, Government, Politics, and Social Structure in Laos: A Study of Tradition and Innovation (New Haven: Yale University Press, 1964); Arthur J. Dommen, Conflict in Laos: The Politics of Neutralization (New York: Praeger, 1964); and Sisouk Na Champassak, Storm Over Laos: A Contemporary History (New York: Praeger, 1961).

4. For historical backgrounds of Laos, see René de Berval, et al., Kingdom of Laos: The Land of the Million Elephants and of the White Parasol (Saigon: France-Asie, 1959); Maha Silva Viravong, History of Laos (Washington: U.S. Joint Publications Research Service, 1958); and Paul Le Boulanger, Histoire du Laos Français: Essai d'une Etude Chronologique des Principautés Laotienne (Paris: Librairie Plon, 1931).

5. As discussed in Francis Watson, The Frontiers of China: A Historical Guide (New York: Praeger, 1966), p. 16. 


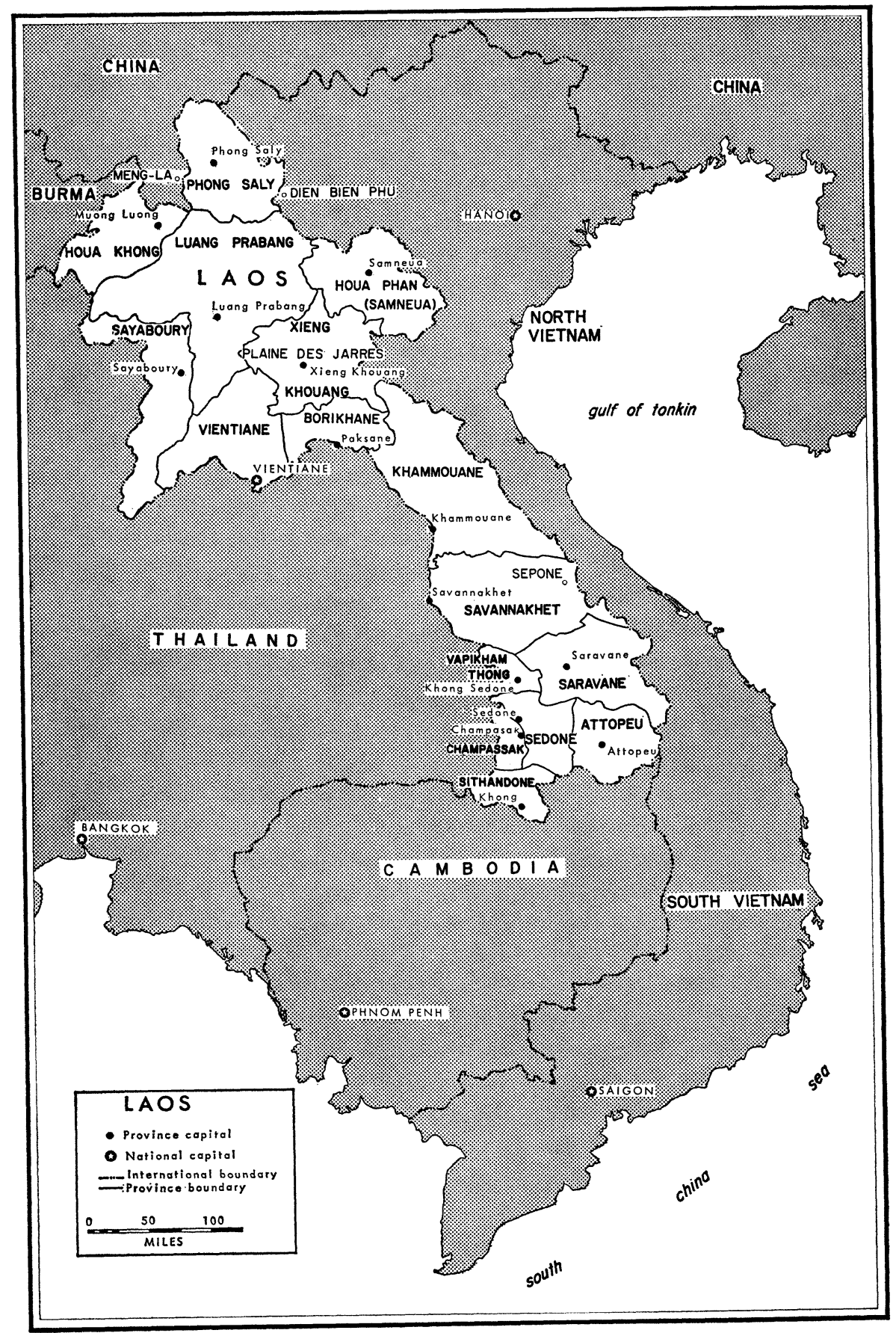

xii 


\section{Chapter I}

\section{The Chinese Communist Conception of Laos}

The Chinese Communist conception of Laos, as of other countries, is apparently based on a delicate and unstable equilibrium between a professed belief in the "universal truth" of Marxism-Leninism and an ethnocentric pursuit of China's national interest. The variations and consequences of this conceptual dualism have indeed characterized the basic pattern of Chinese policy toward Laos from 1954 to 1967.

Communist Ideology: The Chinese invariably manage to harmonize-at least verbally-their ideology and their practical objectives. In theoretical discussions on the relationship between nationalism and internationalism they often equate the concept of national interest (min-tsu-li-i) with "genuine patriotism"-defined as love for one's own fatherland, people, language, literature, and best tradition. Unlike "self-centered and exclusive bourgeois nationalism," they argue, genuine patriotism conforms with the principle of proletarian internationalism; therefore, according to both Mao Tse-tung and Liu Shao-ch'i, a good Communist ought to be a patriot as well as an internationalist and to safeguard the legitimate national interests of his own people. ${ }^{1}$

There can be little doubt that as a set of values and dogmas Communist ideology theoretically guides the Chinese, thus shaping much of their historical outlook and policy preference. Such analytical notions as imperialism, contradictions, class struggle, and dialectical materialism are instrumental to the Chinese in evaluating their domestic and foreign problems and rationalizing their policies and attitudes. ${ }^{2}$ Equipped with what they consider the true and scientific laws of political development, the Chinese are all the more confident after having already learned successful revolutionary strategy and tactics in their protracted struggle against the Kuomintang (KMT). In the perspective of universal ideological commitments they tend to view Laos in the context of a global Communist revolution. But the excessive emphasis on ideology inevitably limits their choice of policy alternative and their freedom of diplomatic maneuvers. For example, this ideological constraint governed the public behavior of Chinese delegates at the Geneva Conferences on Indo-China (1954) and on Laos (1961-62). 
It must be noted, however, that China, like other countries, cannot afford to act simply within a given set of predetermined ideological prescriptions. For Communist doctrine does not offer precise answers to a variety of practical problems and situations. Mao Tse-tung admits that Communism is not a closed system of definite rules applicable to all daily problems; rather, he says, "Marxism-Leninism has in no way exhausted truth but ceaselessly opens up roads to the knowledge of truth in the course of practice." great nation-state like China must preserve its own survival and promote its own interests.

The position of governing responsibilities often demands that ideology be compromised in the interest of political expediency. No doubt, in certain situations, China's national interest can be served by application and exploitation of Communist phraseology. For example, a Marxist interpretation of the policies pursued by United States "imperialists" and Laotian "reactionaries," an endorsement of the proCommunist Pathet Lao's national liberation movement, or Communist propaganda toward progressive elements in Laos-all these may assist Chinese policy. When ideology and expediency conflict, however, the Chinese seem to attach a higher priority to their national interest than to their ideologically inspired commitments. Moreover, they do not hesitate to apply ideology flexibly in the context of Laos " peculiarities."

While they take into full consideration the political reality of Laos and attempt to capitalize on it, they tend to define their national interest toward Laos in the light of their own images, beliefs, and expectations. Hence, they make political judgments according to Chinesenot Laotian-experiences and criteria. Major elements of their national interest are reflected in an extension of China's traditional outlook, which promotes a subtle aspiration for revival of historical hegemony over Laos and a cautious concern with China's national security visà-vis United States' power in Southeast Asia. The possibility of China's economic interest in Laos, unlike Thailand or Vietnam, is almost nonexistent; for Laos lacks raw materials and market value except for certain presumed mineral resources.

Historical Interest: In his opening address to the Eighth National Congress of the Chinese Communist Party (CCP) in September, 1956, Mao Tse-tung warned the audience against a "conceited attitude of 
great-nation chauvinism" in China's foreign relations and said that each sovereign state, irrespective of its size and power, had an equal and independent role to play in international affairs. ${ }^{4}$ Nevertheless the Chinese openly seek a number of special functions in the management of diplomatic issues and in leadership over the revolutionary movement in Laos.

The Chinese hope to gain the mantle of revolutionary leadership by presenting Mao's political thought and strategy as a model for other revolutionaries. Liu Shao-ch'i said in 1947, even before the birth of the Chinese People's Republic (CPR), that one of Mao's primary achievements was to change Marxism "from a European to an Asian form," thus stressing the applicability of Mao's revolutionary formula to nonEuropean conditions. ${ }^{5}$ In a famous article published in September, 1965, Defense Minister Lin Piao emphasized a clear difference in social conditions and revolutionary processes between China and Russia:

The October Revolution took place in imperialist Russia, but the Chinese revolution broke out in a semi-colonial and semi-feudal country. The former was a proletarian socialist revolution, while the latter developed into a socialist revolution after the complete victory of the new-democratic revolution. The October Revolution began with armed uprisings in the cities and then spread to the countryside, while the Chinese revolution won nation-wide victory through the encirclement of the cities from the rural areas and the final capture of the cities. ${ }^{6}$

The universal validity of Mao's model is unreservedly proclaimed in the development of Sino-Soviet ideological polemics and especially during the "Great Proletarian Cultural Revolution." By extending Mao's model into "semi-colonial" and "semi-feudal" Laos the Chinese evidently are trying to become the chief champion and adviser of the Pathet Lao's rural-oriented strategy for "new democratic revolution." According to their rather presumptuous claim, the Laotian people have realized that "Mao Tse-tung's thought is the beacon that guides their war against U.S. aggression and for national salvation." "7

The Chinese also pursue a special role in diplomatic questions regarding Laos. When it was announced in February, 1954, that the CPR would be invited to a Geneva Conference on Korea and Indo-China, People's Daily (February 22, 1954) immediately responded with an enthusiastic editorial saying that China's participation in the Conference was in itself a stride forward toward improving relations among major powers which bore "special responsibility for safeguarding peace 
and security among nations." It made clear that without the participation and consent of China none of the important world problems could be resolved. China, it said, was a member of the "Big Five," as recognized in the United Nations Charter, and its special role simply conformed with the "wishes of the people in all Asian countries."

The point that China shares and represents the wishes and interests of Laos serves to fill an apparent gap between Laos' "equal" and "independent" role and China's special responsibility assumed by virtue of its great power. The identity of common interests between China and Laos rests on historical experiences with imperialism, economic underdevelopment, and aspirations for national unification.

It appears likely that China's self-righteous pursuit of revolutionary and diplomatic leadership represents a continuation of its traditional ethnocentric world outlook and a reassertion of its historical hegemony over Laos. The traditional pattern of relations between the "Middle Kingdom" and its neighboring "barbarians" like Laos was a hierarchical and unequal tributary system. The "barbarians" were supposed to respect China's absolute cultural superiority and to send tributary missions to Chinese courts as a token of that respect. It differed from naked territorial conquest or outright political domination for it was more cultural than political and based less on force than on persuasion. Professor Tsiang concludes:

Since all foreign relations in the Chinese view were ipso facto tributary relations, it followed that all types of international intercourse, if they occurred at all in the experience of China, had to be fitted into the tributary system. ${ }^{8}$

When the Chinese Communists discuss the history of Laos, they usually start from a review of tributary relations between China and Laos as officially recorded in the Chinese dynastic histories. This tendency suggests the extent to which the Chinese perception of Laos is conditioned by tributary experiences.

Although the Chinese documents indicate many earlier contacts with those who had lived in the general area of present day Laos, the formal tributary relationship with an independent Laos was established only after Fa Ngoum unified the area in 1353. In 1403, his son, King Sam Sen Thai, sent the first tributary mission to the Ming court and in turn received an official seal to be used on ceremonial occasions. From that time the courts of Ming and Ch'ing accepted irregularly 
from Laos or its principalities such tribute as elephants, horses, jade, gold, silver, and silk until 1853, approximately every ten years in the eighteenth and nineteenth centuries. Laotian missions were officially recognized, given precious gifts, entertained in the courts, and accompanied by Chinese officials to the border. The Chinese courts, however, did not normally interfere in the intricate power struggles, wars, and rebellions in and around Laos except on a few critical occasions. For example, the Chinese Emperor in 1793 intervened and liberated King Anourouth of Luang Prabang from his captivity in Bangkok. On the basis of these historical records, Chen Yu-lung summarily concluded in People's Daily in August, 1956, that "the peoples of China and Laos had very close cultural relations, very deep traditional friendship, and mutually beneficial contacts without interruptions."

But the Middle Kingdom, with its heavenly mandate (t'ien-ming), regarded itself as the center of the cosmic universe and the absolute leader in the hierarchical international system. Accordingly, the notion of foreign relations with equal, independent, and sovereign states was unthinkable. The Chinese Communists-whose conduct in foreign affairs is often self-centered, over-confident, and arrogant-seem to have inherited this traditional parochial universalism and ethnocentric political behavior. And given the continuity or traditional perspective and interest the Chinese may find it natural to reassert their historic influence over Laos. Their methods may be modern; but, in substance, they are not entirely different from those of the past leaders of the Middle Kingdom.

The new methods and techniques do appear more rational, tactful, and sophisticated than the old imperial ones. This procedural and tactical adjustment is required by the very fact that the CPR no longer enjoys the comfortable status of cultural and political superiority over its neighbors. Certainly a century of foreign aggression and exploitation taught the Chinese that they must modify their traditional world outlook. Now, however, the small and weak neighbors jealously protect their own self-esteem and learn how to use other major powers against growing Chinese and other foreign influence. Furthermore, these states dislike the memory of unequal and inferior tributary relations with the Middle Kingdom and resist any attempt to revive a 
semblance of such relations. This inevitably makes them skeptical and apprehensive about any assertive movement of China. But the Chinese, when confused or frustrated in foreign affairs, are often inclined to return to the familiar and complacent traditional pattern-a state of self-centered dogmatism or self-imposed isolation.

To avoid these two extremes, the Chinese, while claiming their intentions are peaceful and friendly, attempt to mobilize the emerging nationalism among their neighbors against the influx of non-Chinese influence. In countries like Laos, then, they have their own "Monroe Doctrine" of maintaining close contact and eliminating foreign influences. For this purpose many Chinese statements and articles emphasize the theme of "traditional friendship" and "harmonious cooperation" with Laos. For instance, the first Sino-Laotian joint statement signed by Premiers Chou En-lai and Souvanna Phouma in August, 1956, declared:

China and Laos have been friendly neighbors since ancient times. It was only at the end of the past century and as a result of foreign invasion that the ties between our two countries were severed. Now that China and Laos have both regained their independence and freedom, they ardently desire to renew their traditional friendly links. ${ }^{10}$

Since American influence impeded the renewal of this traditional friendship, the Chinese said the two countries should cooperate to eliminate that influence. Only when this was accomplished, they declared, could China and Laos live together in peace and friendship.

Strategic Interest: In addition to this traditional interest the Chinese have a more serious and direct security interest in this land-locked country. As one legitimate reason for their unavoidable interest in Laos the Chinese cite the fact of geographic proximity. They claim a special responsibility for the solution of Laotian questions which the United States or the Soviet Union-not sharing a common border with that country-do not possess. Given their thesis of the "indivisibility of peace" in Southeast Asia, however, the Chinese reason that the problems of war and peace in Laos are not isolated from, but integrated with, the strategic and political complexity of Southeast Asia as a whole. Believing that the United States regards Laos as the gateway to Southeast Asia, they pay particularly minute attention to any strategic move-actual or imagined - of the United States and its allies 
toward that land. Indeed the United States, to effect its containment of Communist movements supported by Communist China and North Vietnam, has taken a number of specific commitments in Laos, ranging from considerable economic assistance to various military maneuvers. ${ }^{11}$

The Chinese regard such U.S. commitments in Laos, as elsewhere in Southeast Asia, as threatening their national security. This preoccupation with security is only one indication of a general sense of insecurity that they have felt in regard to their territorial integrity and military capabilities ever since 1949 . Since then they have occupied themselves with trying to liberate Taiwan, with fighting the Korean war, with several unsettled border disputes, and with the presence of nuclear-tipped U.S. strategic power in Asia. They have also been concerned with the gradual erosion of the Sino-Soviet military alliance system and with their encirclement by a number of bilateral and collective security arrangements forged by the United States and its allies.

As an expression of U.S. policy in Southeast Asia, the Southeast Asia Treaty Organization (SEATO) has become a convenient target of China's indignation and accusations. Undoubtedly the Chinese are well aware of the intrinsic weakness of SEATO as a collective security system; it lacks a standing army, has difficulty in reaching unanimous agreements among its member-states, and needs a complicated procedure to enlist each member's military action in the event of armed conflict. Nevertheless, the Chinese vigorously attacked SEATO's commitment to Laos and its frequent "display of military might" around China's periphery. To counter SEATO's anti-Peking "activities" and "intentions," they relied on propaganda, diplomatic maneuvers, and military pressure. Such notions as a collective peace pact and a nuclearfree zone were used to isolate and weaken SEATO and to gain time for developing China's strategic capabilities.

China's feeling of insecurity is not reduced by Mao's various military concepts and slogans-such as "people's war," "substitution of men for weapons," and "paper-tiger." In a sense these notions are designed to disguise actual Chinese weakness. For example, the thesis that all imperialists and reactionaries are "paper-tigers" is a strategic and ideological substitute for China's inferiority in the face of U.S. 
power. ${ }^{12}$ It preaches strategic contempt for imperialist power in historical determinism, but requires tactical respect and prudent appraisal of imperialist superiority at the present time. The thesis is thus employed to dispel a fear of American military strength, to boost revolutionary morale among anti-imperialist forces, and to counterbalance the arrogance of any superior power. In order to increase their greatpower status, anti-U.S. resistance, and strategic independence from Moscow, the Chinese adopted measures for military modernization, ideological regimentation, and political mobilization.

In the process of realistic strategic assessment the Chinese established the supremacy of vital security interest over universal ideological commitments, recognized their limited military capabilities, and refrained from provoking a direct armed confrontation with the United States over Laos. This strategic calculation-coupled with awareness of the growing nationalist sentiment among the Laotian elite-led the Chinese to preserve a high degree of self-restraint in realizing their traditional interest in Laos. In polemical arguments and declaratory pronouncements the Chinese may sound militant and irresponsible, but in practice they are generally prudent and non-committal, especially in military matters. This gap between words and deeds was eventually to become the subject of a Sino-Soviet controversy; Moscow denounced the "ulterior motive" of China's intentional "bellicose tone" and "phony militancy." For instance, Moscow asserted in June, 1964, that China's leftist phrases meant nothing but a "screen for great power designs and claims to hegemony."13

To suggest that the Chinese are generally prudent and cautious does not necessarily mean they are so fearful that they will never use their armed forces. They have both an optimistic revolutionary conviction and an unshakable forward strategy for global revolution in the long-range historical perspectives. Only within this grand strategy are they careful to avoid the mistake of "infantile adventurism." Even though they are not interested in a general and nuclear war with the United States, they are nonetheless prepared for limited conventional warfare on the Asian continent. And they have persistently demonstrated a presumably genuine determination to deal with a vital threat to their security interest during critical situations both in Vietnam and in Laos. It was believed in 1966 that out of the 2.7 mil- 
lion regular military forces the CPR concentrated more than 300,000 troops and several air force units in the provinces of Yunnan and Kwang-hsi just north of Vietnam and Laos. ${ }^{14}$

Policy Patterns: It has been suggested in the preceding discussion that China's policy objectives in Laos are largely determined by a dualistic conceptual scheme in which ideological considerations are often compromised by or subordinated to the realistic requirements of China's national interest, both historical and strategic. But the specific policy patterns the Chinese adopt in Laos depend upon how they evaluate and manage the interaction between given objectives and available means. The manner in which the Chinese reconcile ends and means and the extent to which they are willing to assume costs and risks involved are a useful measure of their policy rationality. They use diplomatic, propagandistic, and economic instruments in pursuing their policy objectives; they also apply the methods of "people's diplomacy" and exploit the organizations of Overseas Chinese in Laos. Available means of political communications include the Geneva Conferences, the Geneva Co-chairmen (British and Soviet Foreign Ministers), the International Commission for Supervision and Control (ICC), the Pathet Lao organizations, the Democratic Republic of Vietnam (DRV), and the Chinese diplomatic and economic missions in Laos. ${ }^{15}$

In setting out a policy, the Chinese may realize that circumstances in Laos could develop into one of five analytically identifiable political forms: (1) establishment of a unified Communist state, (2) total conquest by a pro-U.S. group, (3) de jure partition, (4) de facto partition, and (5) neutralization. Since the Chinese are primarily, though not exclusively, concerned with their strategic and traditional interests in Laos, they are likely to examine these conceivable forms carefully, but to prefer a medium-range solution of Laos' neutralization and its concomitant devices, including a coalition government with Pathet Lao participation. For a neutralized Laos can offer them a combination of practical advantages lacking in other circumstances. A Laos without hostile foreign military forces or bases can become a useful buffer zone in Southeast Asia and thus help increase a sense of national security among the Chinese. If Laos remains genuinely neutral and friendly, the Chinese can avoid those risky responsibilities that may 
arise in the cases of Communized or divided Laos. Under these favorable conditions they can expect to establish and develop close relations with Laos in diplomatic, cultural, and economic fields. The increase in these relations may help restore their traditional leadership over Laos in a subtle and indirect way.

The concept of neutralization may clash with China's ideology of supporting militant national liberation movements. If, however, the Chinese are reasonably convinced that indigenous revolutionary forces have long-range political advantages in the absence of any foreign interference, they might well reason that such a compromise does not sacrifice the revolutionary movement. The Chinese have apparently had confidence in the Pathet Lao's potential strength. In fact, it has seasoned leaders, experienced troops, integrated organizations, and revolutionary bases in Sam Neua and Phong Saly provinces. And it enjoys some popular local support and has access to Communist China and North Vietnam. At a time when Laos is not ripe for a Communist revolution, it is apparently desirable to the Chinese that the Pathet Lao seek to neutralize Laos, participate in the coalition, consolidate political foundations, and accomplish the new-democratic stage of revolutionary strategy.

Since the early 1950's, when they modified their rigid "two-camp" world outlook, the Chinese have recognized the anti-imperialist tendency of a neutral foreign policy adopted among Asian and African states. They have tried to dissuade these states from joining "aggressive" military systems and encouraged them to form an international united front against imperialism and colonialism. A successful revolutionary strategy, the Chinese assert, requires both military and political forms of struggle, including negotiations with the enemy. Arguing that those who refuse to negotiate under all circumstances are poor revolutionaries, they often quote Mao Tse-tung's dictum of having "all the flexibility permissible and necessary for carrying out our principles." ${ }^{16}$ Hence, a compromise formula of neutralization can be a legitimate means of political struggle necessary for carrying out a "principle."

The neutralization of Laos, striking a reasonable balance between Chinese national interest and Communist ideology and between aspired ends and available means, has steadily proved attractive to the Chinese 
since 1954. Yet the Chinese, as political realists, are skeptical about the viability of a neutralized Laos. For one thing they suspect that the United States would not renounce its containment policy voluntarily. In addition they realize that Laos does not have internal and external conditions favorable for effective neutralization. Moreover, the experiments for Laos' neutralization have been difficult and often frustrating to the Chinese. As a result they have shifted from a moderate policy aiming at a neutralized Laos to a militant policy supporting the Pathet Lao's military activities.

In response to the highly unstable state of Laotian affairs, therefore, the Chinese have continued to adjust and reorient their positions and techniques. During the period under consideration this process of adjustment has taken four broad tendencies: (1) a policy of peaceful coexistence (1954-57), (2) a policy of assertive pressure (1958-60), (3) a policy of negotiations at the Geneva Conference (1961-62), and (4) a policy of reappraisal (1963-67). Although these tendencies were not always distinctive but often overlapped, each of them exhibits a certain pattern of challenge and response and a particular set of objectives, tactics, and consequences.

\section{Notes}

1. See Mao, "The Role of the Chinese Communist Party in the National War" (October, 1938), and "On New Democracy" (January, 1940), in Selected Works of Mao Tse-tung, Vol. II (Peking: Foreign Languages Press, 1965), pp. 195-211, 339-384; and Liu's speech made in November, 1948, in Kuo-chi-chu-i yü min-tsu-chu-i [Internationalism and Nationalism] (Hong Kong: Hsin-min-chu-ch'u-pan-she, 1949), pp. 7-50.

2. For analysis of the role of ideology, see H. Arthur Steiner, "Ideology versus National Interest in Chinese Foreign Policy," in E. F. Szczepanik (ed.), Symposium on Economic and Social Problems of the Far East (Hong Kong: Hong Kong University Press, 1962), pp. 246258.

3. "On Practice" (July, 1937), in Selected Works of Mao Tse-tung, Vol. I (Peking: FLP, 1964), pp. 307-308.

4. Eighth National Congress of the Chinese Community Party: Documents, Vol. I (Peking: FLP, 1956), pp. 7-11.

5. See Anna Louise Strong, "The Thought of Mao Tse-tung," Amerasia (June, 1947), pp. 161-162.

6. Long Live the Victory of People's War! (Peking: FLP, 1965), p. 40.

7. Peking Review (January 12, 1968), p. 17.

8. See John K. Fairbank and Ssu-yu Teng, Ch'ing Administration: Three Studies (Cambridge: Harvard University Press, 1960), p. 141.

9. "Traditional Friendship between China and Laos," in People's Daily (August 21, 1956); for similar assertions, see "Source Material: Friendly Relations between China and Laos," ibid. (April 23, 1961), "Traditional Friendship between China and Laos," ibid. (April 26, 1961), and "Source Material: The Kingdom of Laos," Kwang-ming Daily (March 6, 1963). For a chronological study of tributary relations, see Paul Le Boulanger, op. cit., pp. 190-191, 197, 200.

10. Hsin-hua-pan-yueh-k'an [New China Semi-Monthly] (Peking: 1956, No. 18), p. 1.

11. U.S. economic assistance expenditures for Laos (per capita) from 1956 to 1965 ranked 
third after those for Israel and Jordan. See Kenneth M. Kauffman and Helena Stalson, "U.S. Assistance to Less Developed Countries, 1956-65," Foreign Affairs (July, 1967), p. 721.

12. See Mao, "Talk with the American Correspondent Anna Louise Strong" (August, 1946), in Selected Works of Mao Tse-tung, Vol. IV (Peking: FLP, 1961), pp. 97-101.

13. For example, see the letter of the Central Committee of the Soviet Communist Party sent to the CCP Central Committee on June 15, 1964, Peking Review (July 31, 1964), p. 18.

14. See Chukoku Jimmin Kaihogun [Chinese People's Liberation Army] (Tokyo: Asahi Shimbun, 1967), pp. 73-74.

15. The Chinese Communist Consulate-General headed by Gen. Ting Yung-cheng was established at Phong Saly in October, 1961, and the Economic and Cultural Mission headed by Ho Wei (ex-Ambassador to Hanoi) was sent to Xieng Khouang in November, 1961. The CPR formally set up its Embassy in Vientiane in September, 1962, with Ambassador Liu Ch'un. For full discussions of these developments, see Chapter V.

16. "Report on the Second Plenary Session of the Seventh Central Committee of the Communist Party of China" (March, 1949), in Selected Works of Mao Tse-tung, Vol. IV, op. cit., p. 372 . 


\section{Chapter II}

\section{The Chinese Policy of Peaceful Coexistence}

Section One: China and the First Geneva Formula on Laos

At the time that the Chinese People's Republic (CPR) was proclaimed in October, 1949, there appeared in the Kingdom of Laos a new trend toward diplomatic accommodation with France and domestic political rearrangement. As Laos was granted an independent status within the French Union, many moderate Lao Issara leaders resumed their normal political life in Vientiane and some of them even joined the Royal Laotian Government (RLG). But the establishment of Prince Souphanouvong's "resistance government" against the RLG and France heralded the beginning of Laos' long domestic turmoil and constituted a small part of the broader conflict which was spreading throughout Indo-China under Ho Chi Minh's revolutionary leadership. From the moment Ho formed the Indochinese Communist Party in 1930, he had striven to unify the revolutionary groups in Indo-China and to impose Vietnamese hegemony over Laos and Cambodia. When the Indochinese Communist Party was dissolved and succeeded by the Vietnam Lao Dong Party in March, 1951, its platform clearly revealed Ho's persistent interest in giving every assistance to anti-French movements in Indo-China and in bringing about "an independent, free, strong and prosperous federation of the states of Vietnam, Laos, and Cambodia." Ho's region-wide campaign was soon formalized in an alliance of the national united fronts of Vietnam, Khmer, and Pathet Lao to fight against the French "imperialist invaders."

This alliance was conveniently used to justify commitments of Vietnamese "people's volunteers" on behalf of Souphanouvong's "resistance government" in the following years. Accompanied by a small number of Pathet Lao forces, the Viet Minh made two major thrusts into Laos toward the end of the Indochinese war. In April, 1953, they occupied Sam Neua, advanced in May toward Luang Prabang, and then suddenly retreated to Vietnam. They again invaded Central Laos in December, reached the Mekong River in January, 1954, and moved northward toward Luang Prabang in February only to withdraw. In 
the process Souphanouvong set up his revolutionary bases at Sam Neua and enlarged the "liberated areas"; in February, 1954, he claimed-his estimate was palpably inflated-that the Pathet Lao controlled nearly half of the Laotian territory containing one-third of the population. ${ }^{2}$

It is unclear whether the CPR had any direct contact with the Pathet Lao movement up to this time, outside of Souphanouvong's visits to China during 1951 and 1952, apparently for policy consultations. There is little doubt, however, that the triumph of Communist revolution in China and the presence of Chinese troops on the Indochinese frontier encouraged Souphanouvong's movement and that the extensive Chinese military assistance for the Viet Minh operations indirectly aided the Pathet Lao. As Eden recalls, the Viet Minh could indeed find "refuge, equipment, money and training facilities across the Chinese border" and could get Chinese advisers, technicians, and officers. Undoubtedly the availability of Chinese assistance bolstered the continuous struggles of the Viet Minh and the Pathet Lao as well. ${ }^{3}$

Meanwhile, Foreign Ministers of America, Britain, France, and Russia, meeting at Berlin in early 1954 to discuss the German-Austrian question, agreed to sponsor an international conference to be held at Geneva in April for reaching "a peaceful settlement of the Korean question" and for discussing "the problem of restoring peace in IndoChina." At the insistence of Secretary of State John F. Dulles, who refused to allow any precedent of de facto recognition of the CPR, the Berlin Communique contained a specific understanding that "neither the invitation to, nor the holding of, the above-mentioned conference shall be deemed to imply diplomatic recognition in any case where it has not already been accorded." With McCarthyism on the rise in the United States, the inflexible Dulles said that the CPR would come to Geneva not to be honored by "us" but to account before the bar of world opinion for its aggressive roles in Korea and Indo-China. This vindictive position created some technical problems at the subsequent Geneva Conference; Dulles, for example, opposed a rotating chairmanship which would have devolved upon the Chinese and refused to participate in private discussions or to sign any document with CPR delegates.

Although there was a fear that the Chinese might desire the freedom to intervene in Indo-China, they nevertheless welcomed the invitation 
to attend the Geneva Conference. Hence, People's Daily carried an editorial on February 22, 1954:

The major powers bear a special responsibility for safe-guarding peace and security among nations. If they can solve outstanding disputes through negotiation instead of force, all vital international issues can be settled and relations between the major powers can be made normal. Our fundamental obejctive is to settle the Korean and other Asian questions peacefully, so as to defend the peace and security of the Far East and the whole world.

At the same time, however, the Chinese stepped up their military aid to the Viet Minh, which were then preparing for an all-out assault on the isolated French outposts at Dien Bien Phu in order to gain a decisive military victory before the forthcoming negotiations at Geneva. Both China and the Viet Minh planned to obtain their negotiating objectives through military superiority. The United States estimated that, in addition to Chinese artillery, ammunition, and equipment used in Indo-China, about 2,000 Chinese persons assisted General Vo Nguyen Giap's operations at Dien Bien Phu. ${ }^{5}$

When the Viet Minh besieged Dien Bien Phu-the key to Laos' defense in France's opinion, the United States issued tough warnings against the besiegers and their Chinese supporters, and seriously considered direct military intervention in Indo-China. In March Dulles defined the problem in Indo-China as a "grave threat to the whole free community" and appealed for "united action" among Western powers against the Viet Minh. ${ }^{6}$ But any radical step was restrained by a combination of factors. Both France and Britain desired to give a fair trial to negotiations at Geneva rather than endorse "united action" with America. The specter of another ground war in Asia was unpopular in America. And the United States belatedly realized that a limited use of air power could not itself save the beleaguered French positions.

The Viet Minh victory at Dien Bien Phu on May 7 substantially weakened the negotiating leverage of the Western delegates at Geneva. The Geneva Conference set up two deliberative procedures. One group of nineteen states futilely discussed the Korean question from April 26 to June 15; a second group of nine delegations-the five big powers, three Associated States of Vietnam, Cambodia, and Laos, and the Viet Minh-took part in the Indochinese negotiations from May 8 to July 21. One phase of the Geneva Conference was to end hostilities in IndoChina for a time; but it also promised to secure a number of Chinese 
objectives. It kept U.S. military power out of Indo-China; it demonstrated the status of China as a great power independent of Russia; it finally enhanced China's voice in the management of Asian affairs. In his first speech on the Indochinese question Premier Chou En-lai said the danger of escalating war in neighboring countries required China's close attention, and presented principles to be followed in international politics:

The Asian states should respect each other's independence and sovereignty instead of interfering in each other's internal affairs, should settle disputes among themselves by the peaceful means of negotiations instead of resorting to force or threats, and should establish and develop normal economic and cultural relations among themselves on the basis of equality and mutual benefit instead of permitting discrimination or restrictions. ${ }^{7}$

As the Geneva Conference was the first formal diplomatic contact between the CPR and the Royal Laotian Government, Chou En-lai assumed the responsibilities of two opposing directions-to cultivate cordial relations with Lao Foreign Minister Phoui Sananikone, and to represent the Pathet Lao's revolutionary interest. The art of diplomacy required a judicious balance between these two roles in a manner consistent with China's national interests. Naturally one of his most difficult problems was the legal and military status of the "resistance governments" of Laos and Cambodia. Whereas French Foreign Minister Georges Bidault suggested that the only solution for Laos and Cambodia was to effect the withdrawal of invading Viet Minh troops and restore the full authority of the Royal Laotian and Cambodian Governments, Ho's Acting Foreign Minister Pham Van Dong, Soviet Foreign Minister V. M. Molotov, and Chou En-lai insisted on representation of "resistance governments" at Geneva. They argued that the Pathet Lao controlled over one half of the Laotian territory and more than one million people and that the Khmer Issara, headed by Son Ngoc Minh, occupied over one third of the Cambodian territory and one fourth of the population. Phoui Sananikone, however, responded forcibly to the issue; since the fighting in Laos was the work of Viet Minh troops, he argued, the Pathet Lao "government" had been "fabricated lock, stock and barrel by the foreign invaders."

As Eden correctly foresaw, both Molotov and Chou did not wish to sabotage the entire Conference by urging representation for the Pathet Lao and Khmer "resistance governments." When Dulles seri- 
ously warned of a possible military confrontation between the U.S. and Communist China in June, Chou En-lai, in his discussions with Eden and Bidault, withdrew Communist sponsorship of these "resistance governments." He proposed rather that the Viet Minh delegation should represent them at the military talks with the French Command. Even though Pham Van Dong emphatically denied the presence of Viet Minh forces in Laos and Cambodia, Chou nevertheless told Eden that China could persuade the Viet Minh to withdraw from the two countries and that China would recognize the royal governments of Laos and Cambodia if "there were no American bases in the territory." This suggested that China was more concerned with the security problem arising from possible American bases than with the revolutionary movements in Laos and Cambodia. Indeed, as the most important condition for putting an end to foreign interference, Chou proposed a ban on foreign military personnel and armaments in Indo-China. When the Conference seemed about to collapse, his initiatives constituted a major diplomatic breakthrough on the questions of Laos and Cambodia. Soon thereafter Chou exchanged visits and consultations with Phoui Sananikone and Cambodian Foreign Minister Tep Phan. Furthermore, Chou, in his July talks with new French Prime Minister Pierre MendèsFrance, abandoned Pham Van Dong's proposal for creating the Pathet Lao's autonomous government in the provinces of Phong Saly and Sam Neua.

On July 20-21, 1954, the Geneva Conference adopted a series of agreements for cessation of hostilities in Indo-China and for political settlements in Vietnam, Laos, and Cambodia. ${ }^{10} \mathrm{~A}$ combination of complex political forces made this successful conclusion of the Conference possible: France lost the will to carry on a costly fight against the determined Viet Minh; America failed to exert positive leadership both in the conduct of war and in the process of negotiations; Russia and Britain adroitly mediated the difficult diplomatic entanglements; and China was capable of moderating the extreme positions held by the Viet Minh, Pathet Lao, and Khmer Issara.

In the Final Declaration each member of the Geneva Conference undertook to respect the sovereignty, independence, unity, and territorial integrity of Vietnam, Laos, and Cambodia, and to refrain from interfering in their internal affairs. The RLG promised to take the 
required measures to integrate all citizens, without discrimination, into the national community and to guarantee them their constitutional rights and freedoms, including free participation in general elections. The Government also affirmed a policy of qualified military nonalignment - neither to participate in a military alliance which was inconsistent with the principles of the United Nations Charter or with the provisions of Geneva agreements, nor to permit establishment of any foreign military bases on its soil "unless its security is threatened."

The Geneva agreements required a complete and simultaneous cease-fire to be followed by the withdrawal of French and Viet Minh forces from Laos within 120 days. Excepted were a body of French military personnel-not to exceed 5,000-who were permitted to remain in Laos for the purpose of training the Royal Laotian Army and preserving two French military establishments at Seno and in the Mekong Valley. Chou En-lai first opposed, then accepted, this exception on the assumption that France would respect Laos' military nonalignment and even counterbalance the spread of American military influence there. But, Laos was prohibited from accepting any more foreign military personnel and any type of new armaments other than a specified quantity considered necessary for its national defense. The execution of these accords was to be guaranteed and supervised by the International Commission for Supervision and Control, which was composed of representatives from India (Chairman), Canada, and Poland. It was charged with the broad functions of "control, observation, inspection and investigation" of such matters as the withdrawal of foreign forces, the release of prisoners of war and civilian internees, and the introduction into Laos of military personnel and war materials. ${ }^{11}$

Not only did the Geneva formula of military disengagement and qualified neutralization in Indo-China satisfy the needs of China's campaign against "colonialism" and "imperialism," it also helped secure China against U.S. military intervention in its bordering countries. These results promoted the policy of peaceful coexistence which China had already espoused in the early 1950's upon modifying its earlier position of encouraging violent revolution in Asia. The slogans of "revolution" and "struggle" were therefore replaced by those of "peace" and "cooperation." In his concluding speech at the Geneva Conference 
Chou En-lai explained the significance of the Geneva settlements in this new perspective:

The armistice in Indo-China once again testifies that the forces for peace are irresistible. More and more nations of the world are coming out for peaceful coexistence. No policy of strength aimed at creating splits and forming opposing military groups can have the support of the people. What the peoples of Asia desire is certainly not splits or antagonism, but peace and cooperation. ${ }^{12}$

At Geneva, Chou was one of the dominant diplomats, handling the intricacies of Asian politics at least as skillfully as Eden and Molotov. He conducted important negotiations with Eden, Bidault, and MendèsFrance, especially during Molotov's absence from Geneva. Through the Conference China gained a hearing for its legitimate concern over Laos. The Conference also gave rise to subsequent Chinese strategy and tactics not dictated simply by the fact of geographic contiguity. "For the first time as one of the Big Powers," a People's Daily editorial of July 22, 1954, rejoiced, "the CPR joined the other major powers in negotiation on vital international problems and made a contribution of its own that won the acclaim of wide sections of world public opinion. The international status of the CPR as one of the big world powers has gained universal recognition."

Perhaps China's influence in Indo-China grew at the expense of Ho Chi Minh's interests. As Bell implies, Chou En-lai-together with Molotov-persuaded Ho, who could otherwise have taken Laos and Cambodia within a year, to accept a less favorable settlement than he had a right to expect from military realities. ${ }^{13}$ During a Conference recess in July, Chou flew back to China and met with Ho. A brief joint communique issued after the meetings simply said they fully "exchanged" views on the Indochinese question without indicating the nature of their positions. ${ }^{14}$ Chou apparently soothed Ho's dissatisfaction with the negotiations at Geneva and persuaded him to accept a compromise. Indeed Professor Paul Mus cogently argues that the Chinese in 1954 were engaged in keeping the Viet Minh from carrying out its design to inherit all of French Indo-China. ${ }^{15}$ If so, this only demonstrates a divergence of national interests and regional aspirations between China and North Vietnam in regard to Laos and Cambodia. From the perspective of China's long-range interests, it was obviously desirable to continue the age-old policy of "divide and rule" in Indo- 
China and thus check Ho's aspirations for hegemony in Laos and Cambodia. One can hardly argue that the Chinese considered Laos and Cambodia the permanent sphere of Vietnamese influence.

The unique Geneva arrangements for the Pathet Lao movement eventually proved far more controversial than the Vietnamese and Cambodian settlements. The Pathet Lao's demand for formal autonomy and independent status was completely ignored at Geneva; their acceptance of cease-fire agreements was handled by the Viet Minh delegation. But the Pathet Lao received much better terms than did the Khmer Communists, who were militarily defeated and politically outmaneuvered by King Norodom Sihanouk. The Khmer resistance forces were to be demobilized on the spot within thirty days after the cease-fire order, while the Pathet Lao, "pending a political settlement," was permitted to regroup their troops in the northern provinces of Phong Saly and Sam Neua (Houa Phan). They were also allowed to participate in the nation-wide elections to be held in 1955. The Pathet Lao leaders officially called these Geneva agreements an "initial victory," but they were determined to preserve their fighting capacity until final political settlements with the RLG were achieved.

At Geneva the Chinese exposed a willingness to compromise the Pathet Lao's revolutionary objectives in order to further their own national interests in the region. Only within this basic limit were they prepared to represent and enhance the Pathet Lao's positions and to cooperate with other Communist delegations. Their emphasis on "peace" and "cooperation" at the time of the Geneva Conference harmonized with the peaceful strategy adopted by the Soviet Union. It seems likely, though, that the decision to alter Chinese policy from the rigid formula of uniting with revolutionaries to the flexible one of uniting with all with whom unity was possible was reached independently after a reappraisal of China's internal and external conditions.

At the international level the Chinese evidently had learned through their recent experiences with the Korean and Indochinese wars that it was highly risky and costly to promote revolutions by means of overt violence. They believed that any radical attempt to change the worldwide strategic equilibrium would be effectively resisted by the massive retaliatory power of the United States and its allies. The Korean war, in particular, inflicted great sacrifices upon Chinese forces and revealed 
striking shortcomings in their military technology and training. When their national security was threatened by General MacArthur's proposal to bomb Manchuria during the Korean war and later by Dulles' suggestion to escalate the Indochinese war, the Chinese must have taken stock of their limited strategic capabilities. It is not surprising how obsessed they became with the idea that America might attack. ${ }^{16}$

A second factor contributing to China's prudence was their current program of socialist economic reconstruction, political consolidation, and military modernization. The first Five-Year Economic Plan (195357) required a concentration of their limited resources, human and material, on the domestic front to the detriment of external "adventures." Their economic ambitions at home, coupled with the proven strength of their foreign foes, made it necessary for China to settle for a "peaceful international environment."

In line with the spirit of the Geneva negotiations Chou En-lai launched a broad diplomatic campaign of peaceful cooperation summed up in his five principles of peaceful coexistence. These principles were first promulgated in the Sino-Indian trade agreement of April, 1954, and soon reaffirmed in Chou's separate joint statements with Indian Prime Minister Nehru and Burmese Prime Minister $\mathrm{U}$ Nu in June. ${ }^{17}$ The Chou-Nehru statement, in particular, observed that if these principles were applied in general international relations, they could form a "solid foundation for peace and security" in the world, replacing the existing atmosphere of "fear and apprehension" with a "feeling of confidence." The application of these principles in Indochinese affairs, the statement emphasized, should promote an "area of peace" all over the world. Of course, the Chinese hoped these principles would help protect their national security and allow them to work on domestic progress, while gradually expanding their influence in a neutralized "area of peace" of Indo-China.

However, the devolopment of a Chinese policy of peaceful coexistence in Laos met opposition from the United States. When Dulles' call for "united action" failed, he adopted at Geneva what has been accurately termed a policy of "innocence by non-association." At the concluding session of the Geneva Conference the U.S. issued a unilateral declaration to the effect that it would take note of the cease-fire agreements and refrain from the threat or the use of force to disturb the 
Geneva settlements. But it was made clear that the U.S. would view any renewed aggression as a serious threat to international security and peace. On the same day President Eisenhower said at his press conference that the U.S. was not prepared to join in the Final Declaration because the Geneva agreements contained features which it did not like, and that it was not party to or bound by the Geneva decisions. ${ }^{18}$

This position of "non-association" reflected Dulles' strategic thinking that U.S. capabilities of massive retaliation, not agreements, were the only effective way to rescue from Communist aggression nations unable to defend themselves alone. ${ }^{19}$ When the withdrawal of French forces soon created a power vacuum in Indo-China, this strategic concept-and its corollary the domino theory-gave rise to a system of peripheral military containment designed as a credible threat to the spread of Asian Communism.

In September, 1954, barely seven weeks after the conclusion of the Geneva Conference, the long-considered plan for the Southeast Asia Treaty Organization (SEATO) was accepted in Manila by eight countries. ${ }^{20}$ Article Four affirmed SEATO's objective of collective security:

Each Party recognizes that aggression by means of armed attack in the treaty area against any of the Parties or against any State or territory which the Parties by unanimous agreement may hereafter designate, would endanger its own peace and safety, and agrees that it will in the event act to meet the common danger in accordance with its constitutional processes.

It was clear that SEATO's major purpose was to deter an "aggressive intention" of Communist China, whose advocacy of peaceful coexistence was taken as a ruse. As a defiant challenge to Chinese and North Vietnamese ambitions in Indo-China, SEATO placed Laos, Cambodia, and South Vietnam under its "protection." When Dulles was ambivalent as to the eligibility of these Indochinese states for full membership in SEATO, Eden, apparently recalling his assurance to Chou at Geneva that these states should be debarred from joining any military alliance, opposed the plan. ${ }^{21}$

At any rate it was not surprising that the establishment of SEATO and its protective umbrella provoked Peking's anger. The Chinese immediately accused SEATO of "aggressive intentions" against them and of "total incompatibility" with the Geneva agreements. The United States, however, reached an agreement with France at the end of 
September that both countries would continue to assist Cambodia, Laos, and South Vietnam in "their efforts to safeguard their freedom and independence and to advance the welfare of their people." ${ }^{22}$ The U.S. promised to revise and reinforce the Mutual Defense Assistance Agreement of December, 1950-providing for indirect American military aid to Vietnam, Cambodia, and Laos through France-and to consider direct financial support for the armed forces of the three states.

On this basis the U.S. absorbed as of January, 1955, the cost of maintaining and training the Royal Laotian Army and embarked upon an expensive military and financial assistance program. The following month when Dulles visited Vientiane after attending the SEATO Council meeting, he testified to the importance of Laos in his strategic calculations. He assured Crown Prince Savang Vatthana that under SEATO provisions the U.S. was prepared to defend Laos with air and naval power against any Communist invasion. In turn he advised the RLG to fight the Pathet Lao's subversive acivities rather than negotiate, and stated that U.S. officers in Thailand should train Laotian soldiers for that purpose. ${ }^{23}$ His inclusion of Laos within the U.S. defense perimeter further expanded the scope of anti-Communist containment structures in Asia and gave a psychological boost to the RLG in its continuing conflict with the Pathet Lao.

The shortcoming of the Geneva agreements (notably Article 14), which failed to specify how to interpret and resolve the political and military status of the Pathet Lao dissidents in Phong Saly and Sam Neua provinces, permitted various legal interpretations and left a crucial problem unclear in Laos. The RLG insisted on extending its authority over these disputed provinces while the Pathet Lao wanted to control the "totality" of these provinces until a comprehensive political settlement was achieved. ${ }^{24}$ The controversy became so serious that the International Control Commission emphasized in its first Interim Report that "unless the political settlement envisaged in the Geneva Agreement is not reached at an early date, the provinces might become a source of constant friction and jeopardize the very objectives of the agreement." ${ }^{25}$ In this regard the ICC's role was limited not only by the ambiguity of Article 14 and the absence of elementary cooperation between the RLG and the Pathet Lao, but by the continuing international conflict in Indo-China. Its functions were also impaired by the 
difficulty of communicating in a jungle country and more importantly by the rapid disintegration of the French colonial administrative system which had hitherto linked Laos with France and other parts of IndoChina. With mobility, communication, and inspection nearly impossible, the Commission had to rely on the word of the foreign combatants that each had withdrawn its forces out of Laos.

Under the good offices of the Commission, however, negotiations between the RLG and the Pathet Lao continued intermittently from January to April, 1955. At various stages the Pathet Lao presented a series of demands for political settlement with the RLG: Souphanouvong demanded an "equal status" with the RLG and establishment of diplomatic relations with China and North Vietnam; Kaysone Phoumvihan, representing the Pathet Lao Command, asked the RLG to remove about three thousand Kuomintang forces whom the United States had allegedly transferred from Burma into northern Laos; and Col. Singkapo Chounlamany proposed forming a coalition government with the RLG. ${ }^{26}$ It is hardly unusual that the Chinese paid special attention to Kaysone's claim and responded favorably to Souphanouvong's proposals. But staunch anti-Communist Premier Katay Don Sasorith refused each of these Pathet Lao proposals and rather showed himself willing to depend on U.S. military assistance to disband the Pathet Lao forces and deter interference from Hanoi and Peking. In his memoranda and letters submitted to the Commission in April, he declared that negotiations in Laos were impeded because the Pathet Lao leaders considered themselves "still under the authority of the Viet Minh High Command." He also said North Vietnam had violated the Geneva agreements on numerous occasions by sending Viet Minh soldiers back into Laos. ${ }^{27}$

\section{Section Two: The Bandung "Spirit" and Sino-Laotian Relations}

The unsettled situation in Laos, coupled with the steadily increasing financial and military commitments of the United States, posed an obvious dilemma to China's policy of peaceful coexistence. At Geneva the Chinese had expected that the big power formula would create a neutralized area of peace in Laos and make the RLG friendly toward them. By the spring of 1955, all these expectations were being upset. More important, Dulles declared in March that the United States might 
use tactical nuclear weapons in the event that China attacked Southeast Asia. ${ }^{28}$ Thus, the Chinese must have seen that a peaceful solution of the Pathet Lao question was necessary to prevent Laos from drifting further into the American military camp and to establish Peking-Vientiane diplomatic rapport. If, however, China gave priority to its diplomatic tie with Vientiane, it might amount to withdrawing her support and sympathy from the Pathet Lao and to permitting U.S. power to stifle the movement. But the Chinese, too, recognized the importance of the Pathet Lao-controlled provinces of Phong Saly and Sam Neua, not only as revolutionary bases but as direct means of influencing northern Laos. The best they could expect from this dilemma was a compromise solution-namely, Pathet Lao participation in a coalition government as the quid pro quo for relinquishing Phong Saly and Sam Neua provinces to the RLG authority.

When 29 countries of Asia and Africa met at Bandung in April, 1955, Premier Chou En-lai used the opportunity to maneuver a compromise solution within Laos. He wished to demonstrate China's adherence to a policy of peaceful coexistence with Laos and to develop an understanding with Premier Katay D. Sasorith. At the Political Committee, Chou declared that China would not infringe "one inch" on the territories of Laos and Cambodia and that it had no intention of intervening in their domestic affairs. ${ }^{29} \mathrm{He}$ voiced an "earnest hope" that these two countries would follow the peace-loving path practiced by India and Burma. He subtly implied that, in line with the political stance of India and Burma, both Laos and Cambodia should adopt a genuine neutral foreign policy, foster friendly cooperation with Peking, and refrain from accepting military protection from SEATO or the United States. It should be noted that by sponsoring the Bandung Conference, Nehru hoped to encourage Peking to peaceful relations with these small countries so that they could avoid involvement with SEATO. As Kahin points out, Nehru believed that the more often China publicly pledged to respect the principles of peaceful coexistence with non-Communist countries, the greater would be the moral pressure on China to adhere to its pledge. ${ }^{30}$ At this stage of their relations both Nehru and Chou found a common interest in the relaxation of tensions in Asia.

As a further cooperative measure toward settling the Laotian prob- 
lem at Bandung, Chou joined Nehru in arranging an informal meeting between Katay Sasorith and Foreign Minister Pham Van Dong. This meeting produced the Hanoi-Vientiane agreement in which Pham Van Dong unequivocally stated:

... the political settlement which is due to take place between the Royal Government of Laos and Pathet Lao, by virtue of the Geneva agreements, is a question of internal order which the Royal Government of Laos and Pathet Lao are entirely free to solve in the best interests of the country and people of Laos. ${ }^{31}$

Pham Van Dong and Katay Sasorith also agreed to develop good neighborly relations "within the framework of the five principles defined in the Sino-Indian agreement." The fruitful conclusion of ChouNehru mediation suggested that both Hanoi and Peking were prepared to observe the principle of noninterference in the Laotian "internal order" and thus to encourage a peaceful unification of Laos. This public clarification was deemed necessary in view of Katay Sasorith's deep fear that Hanoi and Peking were attempting to control Laos through the instrument of Pathet Lao dissidents.

Just as he had done at Geneva, Chou again put pressure on Pham Van Dong to normalize relations with the non-Communist government in Vientiane. Admittedly, the formal communique adopted at the Bandung Conference offered a long list of vague resolutions reflecting a compromise of conflicting tendencies among participants; nevertheless, the Conference, in the footsteps of the Geneva Conference, helped China considerably in developing friendly approaches toward Asia and Africa. Chou's skillful salesmanship of peace at public forums and in informal talks gained friends, disarmed enemies, and won the confidence of neutrals. He was apparently pleased with his diplomatic cooperation with Nehru and was anxious to see a negotiated settlement between the RLG and the Pathet Lao leading to a détente between Peking and Vientiane. This hope was expressed in his report to the Standing Committee of the National People's Congress in May, 1955. As one of the major achievements of Bandung, Chou claimed a role in the making of the Hanoi-Vientiane accord, which, he said, would contribute "to the thorough implementation of the agreements of the Geneva Conference and to the consolidation of peace in Indo-China." ${ }^{2}$

To give credence to his diplomatic overtures from Geneva to Bandung, Chou En-lai proposed in July, 1955, at the National People's 
Congress that "the countries of Asia and the Pacific Region, including the United States, sign a pact of collective peace to replace the antagonistic military blocs now existing in this part of the world, so that the collective peace first advocated by the Indian Government may be realized." ${ }^{33}$ He thus tried to counter the effects of military containment which the United States was pursuing in Asia. The presence of U.S. power in Asia, however, prompted China to turn to Russia for nuclear protection and modern armaments. In pursuit of strengthening its alliance with Russia, China sent Defense Minister P'eng Teh-huai to the foundation ceremony of the Warsaw pact in May, 1955, and to Moscow for military consultations the following month.

As far as the Chinese were concerned, the RLG betrayed the Bandung "spirit" first in failing to achieve a reconciliation with Souphanouvong, Hanoi, and Peking. In the months following Bandung, Katay Sasorith again charged North Vietnam with interfering in Laos and put forward a tough precondition for negotiations with the Pathet Lao-i.e., the effective establishment of the royal administration in the provinces of Phong Saly and Sam Neua, a demand spelling defeat for the Pathet Lao. ${ }^{34}$ In a sense both Chou En-lai and Pham Van Dong were shrewdly outmaneuvered by Katay Sasorith, who took advantage of Peking's and Hanoi's commitments to noninterference in the internal order of Laos to seek a military rather than a political settlement. Mistrusting the friendly gestures of Peking and Hanoi, Laos concluded another aid agreement with the United States in July, 1955, to strengthen its military preparedness against the Pathet Lao.

In the year following Geneva, U.S. activities in Laos increased tremendously. Whereas there had been only two American officials in 1953, there were some 45 in 1955; the U.S. military and economic aid of about 50 million dollars during 1955 was several times the total regular budget of the RLG. ${ }^{35}$ Even though the Joint Chiefs of Staff recommended a force goal of 12,000 to 15,000 for Laos, the State Department reached a "political decision" in 1955 that Laos, to protect its security, should increase the size of its army from 15,000 to 25,000. After several attempts at negotiations the RLG and the Pathet Lao again engaged in an armed conflict in late 1955, albeit on a small scale and in a sporadic manner.

Meanwhile the Pathet Lao leaders, to defend against any major 
offensive from Vientiane, consolidated their administrative control in the provinces of Phong Saly and Sam Neua. Recruiting members both by coercion and persuasion, they increased their ranks from about 1,000 at the time of truce to over 4,000 in 1955. Sen. Mansfield alarmingly reported: "There is also evidence that Viet Minh officers and cadres hold key positions in these forces. Chinese units, moreover, are available across the border." ${ }^{36}$ An anti-Communist newspaper in Laos even indicated in November, 1955, that Communist China and North Vietnam had concluded a mutual assistance program to provide the Pathet Lao with Chinese war material and North Vietnamese personnel and to allocate 100 million yuan to the Pathet Lao out of China's 800 million yuan (approximately $\$ 338$ million) in aid given to Hanoi. ${ }^{37}$ It is conceivable that although the Chinese in 1955 gave priority to a negotiated settlement in Laos, they also gave aid to the Pathet Lao to augment its negotiating position or to meet any contingency situation.

After the Pathet Lao leaders boycotted the general elections which the RLG held in December, 1955, they formed a new political party named the Neo Lao Haksat (or Laotian Patriotic Front), whose main purpose was to broaden the Pathet Lao's appeals and activities. The growing tension between the RLG and the NLH inevitably had unfavorable repercussions on Vientiane's relations with Peking and Hanoi. Both Premier Katay Sasorith and Foreign Minister Phoui Sananikone denounced the support which Hanoi and Peking continued to give to the Pathet Lao, and also threatened to avail themselves of the military protection offered by SEATO and the U.S. In early 1956, Katay Sasorith specifically referred to the danger of Asian Communism and said:

Laos has common borders with Red China and North Vietnam and, therefore, is much exposed to Communist menaces. . . . Though Laos is not a signatory of the Manila Pact, it lies within the protective orbit of the Treaty. It is satisfying to receive the promises of the United States [with regard to] their will to defend the principles of security and mutual aid in this part of the world. ${ }^{38}$

Katay Sasorith's blunt anti-Communist tendency seemed to disturb China's policy of peaceful coexistence, especially her hope of making Laos neutral. The Chinese could not hide their displeasure over his position but refrained from issuing direct warnings or diplomatic protests. In trying to improve their international respectability and develop friendly relations with non-Communist neighbors, they sought to con- 
ceal both their "great nation chauvinism" and their support for violent revolutionary movements. The rise of Sinophobia among sensitive neighbors would merely have played into the hands of Americans, who were eager to justify the need of collective security against the Chinese "menace." Although Vientiane moved gradually under Washington's protective umbrella, the Chinese did not take steps to improve their strained relations with Laos. They were watchful but silent. Perhaps they decided to attach less priority to Laos in their foreign affairs, or could conceive of no other option than to tolerate Vientiane's "hardline" policy and wait for the pendulum to swing back in their favor. But the Chinese could take hope from the cabinet crises in Laos which followed the 1955 general elections.

The Chinese position of calculated self-restraint toward Vientiane yielded a political dividend in March, 1956, when Prince Souvanna Phouma resumed the premiership. The opportunity arose for resuming the long-suspended dialogue between Peking and Vientiane, and the prospect for reviving the Geneva formula and the Bandung spirit in Laos brightened. In his inaugural speech to the National Assembly, Souvanna Phouma made it clear that his main internal policy problem concerned the Pathet Lao. To this end he requested the help of the "Big Powers"-obviously including China. ${ }^{39}$ Thus, the Chinese policy of peaceful coexistence elicited a favorable response from the leader of Vientiane, whose political thinking was inspired by Nehru's neutralist policy. Not only was Souvanna Phouma, like Nehru, friendly to Peking at that time, but also he overturned Katay Sasorith's hard-line policy toward the Pathet Lao. Soon Souphanouvong sent a letter to Premier Souvanna Phouma, proposing resumption of negotiations in Vientiane. One month later Souphanouvong followed up this initiative with a proposal that Laos should adopt a neutral foreign policy and form a broad united front against American interference. ${ }^{40}$ These proposals were endorsed by the Committee for the Maintenance of a Peaceful and Neutral Policy (Khana Santiphab), organized in July by Bong Souvannavong and Quinim Pholsena, the latter a protégé of Souvanna Phouma.

In cooperation with the International Commission and the Geneva Conference Co-chairmen, the RLG subsequently held extensive toplevel negotiations with the Pathet Lao delegation in Vientiane in 
August, 1956, and both sides reached agreements on most of the political problems pending since Geneva. In two joint declarations Princes Souvanna Phouma and Souphanouvong resolved to follow a neutral policy, to apply the five principles of peaceful coexistence, and to promote friendly relations with all countries, especially with neighboring states. They also promised to desist from adhering to any military alliance or allowing any country to establish military bases on Laotian territory apart from those provided for in the Geneva agreements. ${ }^{41}$ As to domestic affairs, each pledged to cease all acts of hostility immediately, to guarantee democratic rights and freedoms to all citizens, and to legalize the Neo Lao Haksat. Most important, it was agreed that while the Pathet Lao would place their troops and provinces under Vientiane's authority, the RLG would set up a National Union Government with the participation of Pathet Lao representatives and organize supplementary general elections on the basis of universal suffrage and secret ballot. The specific procedures for coalition, integration, and elections were entrusted to the Joint Military and Political Commissions composed of members from both sides. Thus, the general principles for "political settlement" in Laos which were envisaged in Article 14 of the Geneva agreements and subsequently endorsed at Bandung were finally accepted by half-brothers Souvanna Phouma and Souphanouvong.

Section Three: Peking and the Peaceful Unification of Laos

The Chinese, who had sought a peaceful settlement of the Laotian question since Geneva, immediately supported the Vientiane negotiations. They considered the RLG-NLH rapprochement a major contribution to their policy of peaceful coexistence with Vientiane. Hence People's Daily (August 8, 1956) carried a favorable editorial:

The Chinese people will firmly support the agreements reached in the negotiations, and ardently hope that both sides will continue to march along the road of peace and unification so that at an early date Laos may play its role as a completely independent and unified state in the great family of peace in Asia.

As for the remaining issues of coalition and elections, the editorial urged "rational solutions" and praised the International Commission for its role of mediation in Laos.

China's greatest enthusiasm was directed toward two parts of the 
Vientiane agreements-Laos' declared intentions to develop friendly relations with its neighbors and to formulate a policy of peaceful coexistence and military nonalignment. The Chinese not only expressed their willingness to work toward establishing friendly and diplomatic relations with Laos, but pointed out the merits of a strict neutral foreign policy. By endorsing a neutral policy for Laos and reaffirming their interest in friendship and coexistence, they hoped to nullify their earlier record of opposition to neutralism. In the past their "two-camp" world outlook had underplayed the importance of the third camp or intermediate zone between socialists and capitalists. For example, in his manifesto "On the People's Democratic Dictatorship" [June, 1949], Mao Tse-tung attacked the "illusion of a third road" and stated: "Not only in China but also in the world, without exception, one either leans to the side of imperialism or to the side of socialism. Neutrality is a mere camouflage and a third road does not exist." ${ }^{, 2}$

Mao's dogmatic rejection of neutrality was further elaborated by Liu Shao-ch'i when, in November, 1949, he called such neutral leaders as Nehru, U Nu, and Sukarno "stooges of imperialism" and advised the Communist revolutionaries in these neutral countries to begin armed insurrection after the Chinese pattern. But this extremism gave way in the early 1950 's to a more pragmatic policy of peaceful coexistence with those states having different social systems. So Chou En-lai began to emphasize China's respect for neutral countries, and Liu Shao-ch'i, too, pushed the same theme. At the Eighth National Congress of the Chinese Communist Party in 1956, Liu acknowledged that the overwhelming majority of newly independent Asian nations were pursuing a peaceful neutral foreign policy which put a "powerful check on the colonial aggrandizement of United States imperialism." ${ }^{33}$ This contrasted sharply with Dulles' statement of June, 1956, in which he characterized the notion of neutralism as obsolete, immoral, selfish, and shortsighted except under special circumstances. In response to Dulles' remarks Souvanna Phouma said that "our country has no intention of joining any bloc, even the neutralist bloc." ${ }^{44}$ In apparent reference to the Dulles-Souvanna Phouma exchange, Vice-Premier Chen Yi observed in September that it was not the policy of neutrality which was immoral but rather the "policy of war pursued by the United States monopoly circles themselves." ${ }^{\text {"5 }}$ Against this back- 
ground the Chinese probably saw in Laos' decision to uphold a neutral policy an excellent opportunity to gain rapport with Vientiane and thus draw it from SEATO's embrace.

The enthusiasm with which the Chinese welcomed the Vientiane agreements led to long-awaited direct consultations between Peking and Vientiane. Now that the Pathet Lao question no longer prevented the invitation of Chou En-lai, Premier Souvanna Phouma could feel free to pay his first state visit to China, from August 19 to 26, 1956, accompanied by an impressive 30 -member delegation. ${ }^{46}$ The Chinese seized the opportunity to show their peaceful intentions, to encourage domestic harmony in Laos, and to establish official ties with the RLG. The fact that, of their eleven independent neighbors, only Laos and Bhutan had withheld recognition from the CPR no doubt spurred the Chinese move. Souvanna Phouma, on his part, sought Chinese leaders' personal assurances that they would encourage the Pathet Lao and Hanoi to abide by the Vientiane agreements and live in peace with the RLG. At a banquet sponsored by Chou En-lai, therefore, Souvanna Phouma candidly stated: "Only upon the good faith and sincerity of our surrounding nations, among whom we count upon China, can Laos expect to live peacefully." ${ }^{47}$ The Chinese responded with a pledge to respect the principles of peaceful coexistence and support Souvanna Phouma's efforts for national unification and international cooperation. Noting that peoples of China and Laos were not only neighbors but also relatives, Chou En-lai emphasized that there had never been any conflict between the two countries. Mao Tse-tung also said China and Laos should begin to renew their "historical friendship" on the basis of peaceful coexistence. ${ }^{48}$ In return Souvanna Phouma himself acknowledged the importance of the historical Sino-Laotian relationship. Among other things he noted that one thousand years ago the people of Laos had migrated from China's southern border area to the Mekong valley and that the Laotian missions, despite high mountains and difficult roads, had visited China to bring the "loyal friendship" of Laotian people. He even observed that Laos had survived its turbulent history by inheriting the very great spiritual element fostered in China. ${ }^{49}$

The visit proved to be productive and satisfactory to Peking. In their first joint statement, signed on August 25, Premiers Chou En-lai and Souvanna Phouma noted three points of mutual agreement. ${ }^{50}$ 
First, Laos declared to carry out a policy of peace and neutrality, to decline membership in any military alliance as long as its own security was not threatened, and to refuse the establishment of any foreign military base on its territory other than those provided in the Geneva agreements. China in turn affirmed its respect and support for these policies. Second, both Governments pledged to develop "good neighbor relations" in accordance with the five principles of peaceful coexistence, and to promote in every possible way the cross-border relations between local authorities along the Sino-Laotian boundary. Third, they agreed to develop economic and cultural relations for the greater benefit of the two countries. Apart from the joint statement Souvanna Phouma expressed his willingness to accept the offer of Chinese economic aid and suggested that the Chinese Government send representatives to Laos to make a first-hand investigation of Laos' economic planning.

Although the Chinese could not persuade Souvanna Phouma to establish diplomatic relations at once, they were pleased to win so many commitments. Of special importance to them was Souvanna Phouma's promise to pursue a policy of economic and cultural cooperation with China. Most significant, he, by echoing the central theme of the Chinese campaign that SEATO's protective role over Laos was incompatible with the Kingdom's sovereignty and the Geneva agreements, reversed Katay Sasorith's March, 1956, statement and struck a blow at U.S. policy. Just as Prince Sihanouk did at Peking in February, 1956, Souvanna Phouma declared at a Peking press conference that Laos should never accept SEATO's protection because it was decided "without our participation" and was not consistent with the Geneva agreements. ${ }^{51}$ On the following day, People's Daily (August 26) commented on the importance of the Sino-Laotian agreement and observed:

We firmly believe this agreement will not only revive our long-standing traditional friendship, but also put it on a new basis that will open wide prospects for new development. Those who have plotted to drive a wedge between the two countries and who have resisted the current tendency of peaceful coexistence will be greatly disappointed.

Since Sino-Laotian relations were inevitably entwined with the conflict between Hanoi and Vientiane, the Chinese probably persuaded Hanoi to promote peaceful coexistence with Vientiane-just as they had done at Geneva and Bandung. And they welcomed the joint statement 
signed by Souvanna Phouma and Pham Van Dong in Hanoi as a "vital contribution to peace in Indo-China." ${ }^{\text {22 }}$ In view of recent tensions and suspicions, the statement emphasized that North Vietnam and Laos would respect each other's national sovereignty and territorial integrity, and refrain from interfering in the domestic affairs of the other party. To this end Pham Van Dong reiterated his adherence to the Geneva agreements and the Bandung understanding which Nehru and Chou had helped him conclude with Katay Sasorith.

It was no secret that the United States enormously disliked Souvanna Phouma's soft-line policy toward Asian Communism. U.S. Ambassador J. Graham Parsons persistently advised Souvanna Phouma not to form a coalition government with Pathet Lao dissidents and, to show his dissatisfaction, stayed away from the airport when the Laotian delegation left for Peking and Hanoi. Fully aware of American dissatisfaction, Souvanna Phouma made it clear in September that "we are not ready to establish diplomatic or economic relations with China or North Vietnam." ${ }^{53}$ Once the assistance of Peking and Hanoi was enlisted for his domestic programs, however, Souvanna Phouma determined to carry on discussions with the Pathet Lao. This led to a series of further agreements on domestic and foreign policies from November to December, $1956 .{ }^{54}$ Meanwhile, Premiers Chou En-lai and Pham Van Dong supported the progress of domestic negotiations in Laos. Chou was particularly pleased with Laos' decision to establish diplomatic relations with those neighboring countries which had so requested and to receive unconditional economic assistance from those same countries from the beginning of 1957.

In the spring of 1957, when the Pathet Lao leaders stipulated-as a condition for final political reconciliation with the RLG-that Laos should accept the Chinese aid of approximately $\$ 70$ millions, they were acting in Chinese interest as much as their own. ${ }^{\mathbf{5 5}}$ They argued that this aid would effectively assure Laos of "true neutrality" because it could counterbalance the impact of enormous U.S. aid. For the fiscal years $1955-57$ the United States had committed to Laos $\$ 165.3$ millions, a substantial portion of which was earmarked for strengthening the 25,000-man national army. This sum made Laos the highest per capita recipient of U.S. aid in Southeast Asia. 
TABLE 2

U.S. Foreign Aid to Laos, Fiscal Years 1955-57a

(In Millions of Dollars)

\begin{tabular}{|c|c|c|c|c|}
\hline $\begin{array}{l}\text { Fiscal } \\
\text { Year }\end{array}$ & $\begin{array}{l}\text { Development } \\
\text { Grants and } \\
\text { Technical } \\
\text { Cooperation }\end{array}$ & $\begin{array}{l}\text { Budget } \\
\text { Support }\end{array}$ & $\begin{array}{c}\text { Military } \\
\text { Equipment }\end{array}$ & Total \\
\hline 1955 & $\ldots$. & 40.9 & $\ldots . .$. & 40.9 \\
\hline 1956 & 1.0 & 47.3 & 27.4 & 75.7 \\
\hline 1957 & 1.5 & 42.9 & 4.3 & 48.7 \\
\hline 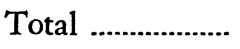 & 2.5 & 131.1 & 31.7 & 165.3 \\
\hline
\end{tabular}

a Source: Arthur J. Dommen, Conflict in Laos: The Politics of Neutralization (New York: Praeger, 1964).

But the possible consequences of Chinese aid programs aroused growing apprehension both in Vientiane and in Washington. It was argued among right-wing Laotian leaders that the acceptance of Chinese assistance and technicians would eventually lead to diplomatic recognition of Peking and increase the Pathet Lao's political strength in Vientiane. The United States too was fearful of Communist penetration into Southeast Asia under the cover of aid, peace, and neutrality. For, as SEATO's second annual report put it, "despite statements stressing the feasibility of peaceful coexistence between Communist and non-Communist nations .... the ultimate objective [of Communists] in the Treaty area continues to be the establishment of disciplined Communist regimes." ${ }^{\text {"6 } 6}$ It also said the Communist exploitation of "neutralism" was incompatible with collective defense organizations in the region.

A Chinese presence in Laos would threaten America's containment policy in Southeast Asia. Accordingly, the United States expressed more forcibly than ever its disapproval of Souvanna Phouma's conciliatory posture. In an unusual move the U.S. Government protested to Laos in April, 1957, that the objectives of Laotian national unification had been made impossible because the Pathet Lao forces placed "extraneous conditions" upon their acceptance of the RLG authority and upon their reintegration into the national community. ${ }^{57}$ This diplomatic note asked the RLG to act with determination so that "the political future of the Kingdom of Laos shall not be dictated by dissident groups enjoying no constitutional status." A week later a State Department spokesman cited the following as examples of Pathet Lao's extraneous 
conditions: first, neutrality involving the exchange of diplomatic representatives with the Communist bloc; second, acceptance of economic and technical assistance from the Communist bloc, particularly Communist China; and third, establishment of a coalition government including the Communists. It was even hinted that should these measures of appeasement go into effect, the United States would cut off its aid to Laos.

The U.S. move was designed as a "psychological lift" to the vulnerable RLG in its attempt to resist Communist pressures. As evidence of China's southward thrust, U.S. "observers" in Vientiane reportedly confirmed that two Chinese and several North Vietnamese battalions were stationed within Laos. ${ }^{58}$ This American fear of Chinese expansionism in Southeast Asia was well expressed in a joint statement signed by Presidents Eisenhower and Ngo Dinh Diem in May. They noted with alarm that "the continued military buildup of the Chinese Communists, their refusal to renounce the use of force, and their unwillingness to subscribe to standards of conduct of civilized nations constitute a continuing threat to the safety of all free nations in Asia." 59

Aware of the latent opposition to its involvement in Southeast Asia, China did not make any overt countermove against Vientiane or Washington for fear of aggravating the delicate political situation in Laos. She contented herself instead with publicizing Souphanouvong's statement denouncing the U.S. pressure as an attempt to destroy the Laotian people's desire for coalition and peaceful foreign relations. To counter such a "crude interference," Souphanouvong called on all Laotians to unite- "irrespective of class, religion, and political tendency"-to preserve the "fatherland, religion and the Crown." ${ }^{60}$ By arousing such hostility toward the United States, he hoped to counter the criticism that the Pathet Lao represented foreign ideology and foreign powers, especially China and North Vietnam.

Amidst these cross-currents of internal and external pressures Souvanna Phouma, proclaiming the purity of his intentions, told the National Assembly in May, 1957, that, although Laos agreed "in principle," it could not at the moment accept Chinese aid. Compelled to resign as premier shortly thereafter, he was reappointed in August to form a six-member emergency cabinet. $\mathrm{He}$ again promised not to "sacrifice our old civilization, our religion, our customs, and institutions 
on the altars of the East or the West." ${ }^{\text {11 }}$ The U.S., however, frankly disliked Souvanna Phouma's blindness toward Asian Communists. Speaking at the U.N. Special Political Committee in October, 1957, U.S. representative Genoa S. Washington complained about the presence of Viet Minh cadres in Laos, the importation of "voluminous quantities of arms" from Communist countries, and "a constant stream of Chinese Communist military personnel" entering Laos. ${ }^{62}$

Despite U.S. pressure Souvanna Phouma steadfastly resumed negotiations with the Pathet Lao in Vientiane, and by November reached a complete settlement of all pending problems within the framework of the agreements of November and December, $1956 .{ }^{63}$ Soon Souphanouvong formally transferred the authority over Phong Saly and Sam Neua provinces to Crown Prince Savang Vatthana and swore allegiance to the Kingdom on behalf of all Pathet Lao officials and soldiers. The National Assembly unanimously approved Premier Souvanna Phouma's National Union Government, which included Katay Sasorith (Minister of Interior and Social Welfare), Phoui Sananikone (Foreign Minister), and two Pathet Lao representatives-Souphanouvong (Minister of Reconstruction and Planning) and Phoumi Vongvichit (Minister of Religion and Fine Arts). It was agreed that the supplementary general elections for the National Assembly would be held in May, 1958. The Pathet Lao also maintained great influence in Phong Saly and Sam Neua provinces, where the leading administrative personnel were selected equally from the RLG and the Pathet Lao. In February, 1958, 1,501 Pathet Lao soldiers were officially integrated into the Royal Army and, a few days later, another 4,284 Pathet Lao soldiers and 1,479 civilian personnel were discharged. The Pathet Lao also surrendered 4,773 weapons which included 23 machine guns, 10 automatic rifles, and 65 mortars. ${ }^{64}$ This was perhaps the first significant experiment in which Communist revolutionary leaders voluntarily surrendered their war materials and agreed to disband more than $70 \%$ of their armed forces. The peaceful progress of military and administrative integration set the tone of the International Commission's Report which confidently observed that "peace has at last been restored in Laos." 65

Although its threatened suspension of aid in April failed in its objective, the United States continued to oppose the movement toward "neutralization" in Laos. Asian Communists, it was argued, would 
penetrate and subvert a coalition government; or such "expansionist" states as China or North Vietnam would effect a takeover. As a nation most deeply involved in Laotian affairs since Geneva, the United States explained its position in a statement issued by a State Department spokesman:

The United States feels, however, that a coalition with the Communists is a dangerous line of conduct, for the history of similar coalition elsewhere in the world reveals that they end tragically in penetration and seizure of the country by the Communists. Consequently the evolution of the situation in Laos is a source of serious concern to the United States, which is observing very closely the situation in that country. ${ }^{66}$

This "serious concern" was widely shared in the United States; for example, an editorial in the New York Times (December 13, 1957) commented that " a perilous experiment which cost the Eastern European nations their freedom and contributed to the debacle in China has started." The American suspicions about this "risky gamble" grew in 1958, in spite of Souvanna Phouma's personal assurances that the Communist ideology could not penetrate the Buddhist-inspired civilization of Laos. ${ }^{67}$

Unlike the United States, China apparently considered peaceful unification of Laos a major victory for its policy of peaceful coexistence. Having dissipated the tensions and suspicions growing from the Pathet Lao problem, Peking and Vientiane could reasonably expect to implement the spirit of the 1956 Sino-Laotian joint statement in various fields with a view to normalizing diplomatic relations. Moreover Peking could influence the direction of Laotian politics through two Pathet Lao Ministers who, as lawful partners of the RLG, constituted a built-in check against America's military and economic influence. Since the question of Chinese aid to Laos had proved controversial in the past, no reference was made to it in the Vientiane settlements. But the fact that Souvanna Phouma accepted it in principle still left the door open for the beginning of Sino-Laotian economic cooperation.

While welcoming and endorsing the modus vivendi reached in Laos, the Chinese nonetheless were wary of its future, particularly in view of the serious concern voiced by the U.S. They promptly warned against any U.S. plan to meddle in the internal affairs of Laos and to set up a military base there for threatening China and Vietnam. Wish- 
ing to forestall this possibility, People's Daily (December 10, 1957) presented a broad but vague suggestion:

When the formation of the National Union Government in Laos and the contribution of the International Control Commission is congratulated, the Laotian people, the Geneva Conference participants and the International Control Commission should continue their efforts to realize a thorough implementation of the Geneva agreements in Laos and to uphold the agreements for non-interference and no military establishment in Laos.

Needless to say, the Chinese concern about the prospects for a unified Laos reflected the underlying conflict of interests among contending Laotian groups and, more importantly, the persistent confrontation between China and America in Southeast Asia.

Through their experiences with Laos during the 1954-57 period the Chinese evidently learned that their early optimistic expectations formed at Geneva were effectively undermined by U.S. determination and strength in Laos. The Geneva Conference provided a rare opportunity for direct Sino-American diplomatic dealings, but neither country took any substantial initiative to improve their relations except for a brief meeting between Wang Ping-nan and U. Alexis Johnson in June, 1954. At the Bandung Conference, Chou En-lai expressed his willingness to seek peaceful settlements of disputes with the United States for the "relaxation of tension" in the Far East and for the "postponement and prevention of a world war." This overture resulted in the bilateral ambassadorial talks which started in Geneva in August, 1955. But Dulles' policy of isolating the CPR diplomatically and militarily prevented productive discussion. Only one agreement-on the exchange of persons -was reached. A basic cause of Sino-American tensions remained the Taiwan issue. The United States protected Nationalist Chinese interests in the world community, continued to maintain the Seventh Fleet in the Taiwan Straits, and pledged to defend Taiwan in the Mutual Defense Treaty of December 2, 1954. Thus, the CPR saw America as rejecting its legitimacy, disrupting its territorial integrity, and posing a threat to its national security. The resulting aggravation of SinoAmerican conflict, together with the working of disruptive forces within Laos, cast an ominous shadow over the prospect of preserving an integrated Laos. 


\section{Notes}

1. See Allan B. Cole (ed.), Conflict in Indo-China and International Repercussions: A Documentary History, 1945-1955 (Ithaca: Cornell University Press, 1956), p. 105.

2. Hsinhua News Agency: Daily News Release, February 18, 1954; in May, he was to claim one-half of the total Laotian population under his control (ibid., May 28, 1954).

3. See The Memoirs of Anthony Eden: Full Circle (Boston: Houghton Mifflin, 1960), p. 88; and Ellen J. Hammer, The Struggle for Indochina, 1940-1955: Viet Nam and the French Experience (Stanford: Stanford University Press, 1966), pp. 248-254.

4. Denise Folliot (ed.), Documents on International Affairs 1954 (London: Oxford University Press, 1957), pp. 78-79.

5. Cora Bell, "Crisis in Asia," in F. C. Benham (ed.), Survey of International Affairs, 1954 (London: Oxford University Press, 1957), pp. 26-28.

6. See his speech made on March 29, 1954, in Department of State Bulletin (April 12, 1954), p. 540

7. See his May 12 speech, Jih-nei-wa-hui-i wen-chien-hui-pien [Collected Documents on the Geneva Conference] (Peking: 1954), pp. 163-169.

8. Great Britain, Documents Relating to the Discussion of Korea and Indo-China at the Geneva Conference, April 27-June 15, 1954 (London: HMSO, 1954, Cmnd. 9186), pp. 116, 155.

9. Full Circle, op. cit., p. 145.

10. Great Britain, Further Documents Relating to the Discussion of Indo-China at the Geneva Conference, June 16-July 21, 1954 (London: HMSO, 1954, Cmnd. 9239).

11. The Communist delegations first proposed a four-nation Neutral Supervisory Commission consisting of representatives from India, Pakistan, Poland, and Czechoslovakia; on the other hand, Eden and Bidault were inclined toward a Commission composed of the five Colombo powers-India, Pakistan, Burma, Ceylon, and Indonesia. In his discussion with Eden in July, Chou En-lai proposed the Commission presently constituted.

12. Jih-nei-wa-hui-i . . . op. cit., pp. 272-273.

13. Bell, "The Geneva Conference," in F. C. Benham (ed.), op. cit., pp. 70-71.

14. Chung-hua-jen-min-kung-ho-kuo-tui-wai-kuan-hsi-wen-chien-chi, Vol. III [Documents on Foreign Relations of the Chinese People's Republic] (Peking: 1958), p. 117.

15. As explained in John T. McAlister, Jr., "The Possibilities for Diplomacy in Southeast Asia," World Politics (January 1967), p. 273.

16. For an evidence of Chou En-lai's obsession with such at Geneva, see Anthony Eden, Toward Peace in Indo-China (Boston: Houghton Mifflin, 1966), p. 4.

17. These are: (1) mutual respect for each other's territorial integrity and sovereignty; (2) mutual nonaggression; (3) noninterference in each other's internal affairs; (4) equality and mutual benefit; and (5) peaceful coexistence. See Chung-hua-jen-min-kung-ho-kuo . . . , op. cit., pp. 10-14, 314-317.

18. Department of State Bulletin (August 2, 1954), pp. 162-163.

19. Dulles, "Policy for Security and Peace," Foreign Affairs (April, 1954), p. 156.

20. See American Foreign Policy, 1950-1955: Basic Documents, Vol. I (Washington: USGPO, 1957), pp. 912-916.

21. Eden, Full Circle, op. cit., p. 145.

22. Department of State Bulletin (October 11, 1954), p. 534.

23. New York Times, February 28, 1955.

24. First Interim Report of the International Commission for Supervision and Control in Laos, August 11, 1954 to December 31, 1954 (London: HMSO, 1955, Cmnd. 9445), pp. 7076.

25. Ibid., pp. 51-52.

26. For these proposals, see Hsin-hua-yueh-k'an [New China Monthly] (Peking), 1955, No. 2, p. 88; No. 3, p. 117; No. 4, pp. 50-54; and Second Interim Report of the International Commission for Supervision and Control in Laos, January 1-June 30, 1955 (London: HMSO, 1955, Cmnd. 9630), p. 10.

27. See Application au Laos des Accords de Genève: Memorandum adressé le 13Avril 1955 à la Commission Internationale de Surveillance et de Contrôle au Laos (Saigon: Imprimerie Française d'Outre-Mer, 1955), pp. 21-22, 27-28; and Second Interim Report, op. cit., pp. 551552.

28. Department of State Bulletin (April 4, 1955), pp. 551-552.

29. George McT. Kahin, The Asian-African Conference: Bandung, Indonesia, April 1955 (Ithaca: Cornell University Press, 1956), p. 60.

30. Ibid., p. 8. 
31. Hsinhua News, April 25, 1955.

32. China and the Asian-African Conference: Documents (Peking: FLP, 1955), p. 51.

33. "The Present International Situation and China's Foreign Policy," People's China (August 16, 1955), p. 8.

34. See Application au Laos des Accords de Genève, op. cit., pp. 43-46, and a mimeographed Addendum to Application ..., pp. 3-4.

35. See Vietnam, Cambodia, and Laos: Report by Sen. Mike Mansfield (Washington: USGPO, 1955), pp. 18-19.

36. Ibid., p. 18.

37. Quoted in Chang Ta-chün, Liao-kung-wen-t'i [Problems of Laotian Communists] (Hong Kong: 1955), pp. 43-44.

38. Quoted in Bernard B. Fall, "The International Relations of Laos," Pacific Affairs (March, 1957), p. 29.

39. Third Interim Report of the International Commission for Supervision and Control, Iuly 1, 1955 to May 16, 1957 (London: HMSO, 1957, Cmnd. 314), pp. 52-53.

40. Ibid., p. 54.

41. Ibid., pp. $54-57$

42. Conrad Brandt, Benjamin Schwartz, and John K. Fairbank (eds.), A Documentary History of Chinese Communism (Cambridge: Harvard University Press, 1952), pp. 453-454. This quotation is completely omitted from the recent Peking publications of Mao's selected writings both in Chinese and English, perhaps because this critical comment on neutrality would adversely affect Peking's relations with neutral states.

43. Liu, "The Political Report of the Central Committee of the Communist Party of China to the Eighth National Congress of the Party" (September 15, 1956), in Supplement to Hsinhua News, September 16, 1956.

44. See Hans J. Morgenthau, Dilemmas of Politics (Chicago: Chicago University Press, 1958), pp. 186-188; and Russell H. Fifield, The Diplomacy of Southeast Asia: 1945-1958 (New York: Harper and Brothers, 1958), p. 363.

45. "The Present International Situation and Our Foreign Policy" (September 25, 1956), Hsinhua News, September 26, 1956.

46. The delegation included: Vice-Premier Katay Sasorith, Interior Minister Tiao Somsanith, Finance Minister Leuam Insisiengmay, Secretary-General of the Cabinet Sisouk Na Champassak, Chief-of-Staff Gen. Sounthone Pathammavong, Representative Bong Souvannavong, Rep. Quinim Pholsena, Rep. Chao Boun Oum, and Rep. Khampheng Boupha.

47. Hsinhua News, August 22, 1956.

48. Hsin-hua-pan-yueh-k'an, 1956, No. 18, pp. 2-3, 5-6.

49. Ibid., pp. 6-7.

50. Ibid., p. 1 .

51. Hsinhua News, August 26, 1956.

52. See People's Daily editorial, August 31, 1956; for the Hanoi-Vientiane joint statement, see Hsinhua News, August 30, 1956.

53. New York Times, September 5, 1956.

54. Third Interim Report, op. cit., pp. 60-67.

55. New York Times, May 13, 1957.

56. Department of State Bulletin (March 25, 1957), pp. 496-503.

57. Ibid., May 13, 1957, pp. 771-772.

58. New York Times, May 14, 1957.

59. Department of State Bulletin (May 27, 1957), pp. 851-852.

60. Hsin-hua-pan-yueh-k'an, 1957, No. 12, pp. 174-175.

61. Fourth Interim Report of the International Commission for Supervision and Control in Laos, May 17, 1957 to May 31, 1958 (London: HMSO, 1958, Cmnd. 541), p. 46.

62. Department of State Bulletin (November 25, 1957), p. 855.

63. See the agreements of November 2 and 12, 1957, in Fourth Interim Report, op. cit., pp. 57-67.

64. Bernard B. Fall, "The Pathet Lao: A 'Liberation' Party," in Robert A. Scalapino

(ed.), The Communist Revolution in Asia (Englewood Cliffs: Prentice-Hall, 1965), p. 185.

65. Fourth Interim Report, op. cit., p. 6.

66. Quoted in Sisouk Na Champassak, Storm Over Laos, op. cit., p. 60.

67. Laos Information Bulletin (Washington: Royal Embassy of Laos, January, 1958), p. 9. 


\section{Chapter III}

\section{The Chinese Policy of Assertive Pressure}

Section One: Collapse of the Policy of Peaceful Coexistence

The preceding chapter has shown how China's emphasis on peaceful coexistence in Laos contributed to a series of agreements at Geneva (1954), Bandung (1955), Peking (1956), and Vientiane (1957). These achievements, however, were challenged in the following years by forces evolving in both Laos and China. By the fall and winter of 1957, the Chinese, preparing for their ambitious "Great Leap Forward," had already started to foment a mood of revolutionary radicalism. With Russia in possession of intercontinental missiles and satellites, Mao Tsetung offered a succinct new appraisal of the balance of international forces; the East wind, he declared in November, 1957, was now prevailing over the West wind. ${ }^{1}$ He clearly meant that the balance was tilted decisively in favor of the socialist camp. This view departed substantially from the strategic stalemate between East and West, the underlying assessment that had made for peace in the early 1950's. This change in China's domestic politics and world outlook began just as an alliance of conservative groups was gaining power in Laos with America's advice and support.

These groups were challenging the former Pathet Lao members well before May, 1958, the date set for the supplementary general elections for the National Assembly-elections which could reveal how far the illiterate electorate supported the Pathet Lao and how durable was the unification of Laos. The election campaign for twenty additional deputies and one vacant seat was marked by the heightened emotionalism which accompanied the renewal of old conflicts over ideology and personalities. It made the free and democratic contest extremely acrimonious and rendered the political fate of the Neo Lao Haksat party unpredictable. In his letters written to the International Commission and the RLG authorities, Souphanouvong registered a formal protest against the "systematic discriminations and reprisals" which some Cabinet Ministers, including Katay Sasorith and Phoui Sananikone, were applying against ex-Pathet Lao members. He asked that these 
tactics, aimed at "reviving, rousing and poisoning the old hatred," be eliminated..$^{2}$

Even though the Chinese were skeptical of parliamentary methods, they carefully watched the Laotian elections as indicative of the NLH's political future and even the possible fate of Asian Communist movements in future contests. Since right-wing politicians in Laos attacked the NLH during the campaign as a puppet of foreign powers, both Peking and Hanoi were careful not to show any direct support for the NLH candidates. Rather, they accused the United States of sabotaging the chance for a "just and fair" election. Perhaps they remembered how the United States, fearful of Ho Chi Minh's immense popularity and organization, had discouraged Ngo Dinh Diem from holding elections in July, 1956, as envisaged in the Final Declaration of the Geneva Conference. "The U.S. aim in Laos," People's Daily commented on May 1, 1958 , "is to create antagonism between the different political parties and wreck the atmosphere of unity in the country so that it can fish in troubled water." To frustrate this aim and effect a united front of patriotic forces, the paper suggested:

The Government of the Kingdom of Laos and patriots from all ranks of society in the country should strengthen their unity and oppose United States intervention, thus creating more favorable conditions for the peaceful unification of Laos.

On the eve of the election, People's Daily again carried a conspicuous editorial with a mixture of advice for and intimidation of Laos and America; only a fair election, it indicated, would serve the interest of peace in Indo-China. No doubt the Chinese were also making provision for future moves in the event the NLH were defeated in the election.

The precaution proved unnecessary, as the NLH won an impressive victory. Nine of their thirteen candidates were elected, and Souphanouvong received the largest popular vote in the country. Their success was not limited to their northern strongholds of Phong Saly and Sam Neua, but widely spread over such southern and central provinces as Luang Prabang, Vientiane, Khammouane, Saravane, and Savannakhet. ${ }^{3}$ Whereas 85 candidates of the Nationalist, Independent, and other conservative parties were hopelessly divided among themselves, the NLH and the neutralist Santiphab combined their strength to win a majority of 21 contested seats. This NLH triumph apparently pleased the Chi- 
nese, who praised it as a "new important development" in Laotian political life and as the implementation of the Geneva agreements.

But it is clear that the Chinese endorsed the NLH's parliamentary method from tactical considerations rather than from theoretical requirements. In their "Outline of Views on the Question of Peaceful Transition" submitted in November, 1957, to the Soviet Communist Party, the Chinese said it was inappropriate to overemphasize the possibility of a peaceful transition. They argued that neither the universal law of class struggle nor revolutionary experiences vindicated that possibility and that an unwarranted stress on peaceful tactics would disarm the revolutionaries ideologically and weaken their fighting will. ${ }^{4}$ As a correct revolutionary formula, therefore, the Chinese suggested the simultaneous use of dual tactics, both peaceful and violent. In an attempt to dispel any illusions the NLH leaders might cherish about the parliamentary road, the Chinese forthwith set a limit to what the elections could achieve and emphasized the probable counteroffensive of U.S. "imperialism." For this reason they publicized Souphanouvong's warning that since the May elections were only an "initial victory," the Laotian people should maintain the vigilance and solidarity against possible U.S. "conspiracies."

But the NLH's successful tactics almost caused panic in Vientiane and in Washington. Before the elections some State Department officials had confidently predicted that the NLH would get three or four seats at best. Now, however, they realized that the NLH was a definite threat to win a parliamentary majority in the next general elections. ${ }^{6}$ Apparently to disrupt Souvanna Phouma's coalition government with the NLH Ministers, the United States suspended a monthly aid payment to Vientiane and advised him to terminate his cooperation with the NLH. Equally alarmed by the NLH's potential threat, the Nationalists and the Independents merged in June to form the Rally of the Laotian People, an anti-Communist united front under the joint leadership of Souvanna Phouma, Katay Sasorith, Phoui Sananikone, and Pheng Phongsavan. In the process Souvanna Phouma himself warned against the spread of Communist ideology and activity in Laos. The resulting line-up in the National Assembly was: the RLP-36, the NLH-9, the Santiphab-7, Democrats-3, National Union Party-2, and Non-affiliated-2. Excluded from the Assembly was a new anti- 
Communist Committee for the Defense of National Interest (CDNI), which a few young intellectuals, junior bureaucrats, and military officers organized in June, for the purpose of outlawing all political parties with "revolutionary tendencies" and stopping Communist infiltration into the Administration. ${ }^{7}$ In the new political arrangements in Laos, therefore, the CDNI emerged as the most militant organized opposition to the NLH.

With the election accomplished, the International Commission-an instrument, by Chinese thinking, to protect the NLH's political freedom and check the military encroachment of the United States-could no longer justify its presence. On the ground that the supplementary general elections constituted the last phase of the implementation of the Geneva arrangements concerning Laos, Premier Souvanna Phouma and Foreign Minister Phoui Sananikone requested in May, 1958, that the Commission terminate its operations in preparation for leaving Laos. ${ }^{8}$ As the formal procedures for Pathet Lao's integration were followed, they reasoned, the Commission's role in Laos' domestic affairs was at an end. That this request spelled the doom of the Geneva agreements was clear enough to the Chinese who, together with Hanoi and Moscow, lodged a strong protest against it. The Chinese arguments to justify the Commission's continuation were threefold. First, the supplementary elections left many problems still unresolved in Laos, including the resumption of discriminatory acts. Second, in the Commission's absence, the United States would step up its interference, thus disturbing Laotian peace and neutrality. Finally, the Commission's presence in Laos should be considered in connection with existing conditions in Vietnam and Cambodia. So long as political difficulties were not fully resolved in three Indochinese states, the Chinese concluded, the Commissions should attend to the duties prescribed by the Geneva agreements. $^{9}$

As diplomatic pressures from Hanoi, Peking, and Moscow increased, India joined Poland to reject the Canadian proposal for "immediate dissolution" of the Commission in Laos. In July, however, India and Canada, in a majority vote against Poland, decided to adjourn the Commission sine die, but to reconvene it, if necessary, "in accordance with normal procedures."10 Even after this decision was taken, there remained the problem of interpretation. The Soviet Union, for example, 
eventually acknowledged the decision for adjournment as a procedural one, while both China and North Vietnam continued to call the decision "illegal and void" on the ground that it was made in violation of the principle of unanimity and without consultations with the Commissions in Vietnam and Cambodia. But the protests and caveats from Peking and Hanoi failed to stop the subsequent departure of the Commission from Laos. ${ }^{11}$

This controversy over the Commission's status took place in the middle of a political crisis in Laos; four days after the Commission decided to adjourn, Premier Souvanna Phouma tendered his resignation - putting an end to the seven-month-old coalition experiment with the $\mathrm{NLH}$ representatives. He resigned in protest of America's persistent opposition to his policy of neutrality and coalition. In this connection it is important to note that even before the votes for supplementary elections were fully counted in May, Deputy Assistant Secretary of State Parsons testified at the House Foreign Affairs Committee that the United States had "some basis for hoping that when the present government [of Souvanna Phouma] resigns ... a government may be formed which does not include Communists."12 Indeed, when Phoui Sananikone formed a new government in August, in cooperation with Katay Sasorith, the NLH Ministers were ignored.

This heralded a radical reorientation in Vientiane's domestic and foreign policies. In his inaugural address at the National Assembly, Phoui Sananikone voiced his determination to fight against "Communist infiltration and development" in Laos. ${ }^{13}$ He redefined "neutralism" in such a manner as to commit his government to an antiCommunist foreign policy, and made it clear that Laos would stand unequivocally with the "Free World." In the winter of 1958, Phoui Sananikone further angered both Peking and Hanoi by strengthening Laos' political and economic ties with Taipei and Saigon; after consultations with Ngo Dinh Nhu (President Ngo Dinh Diem's brother and adviser) and Dr. Hang Li-wu (Nationalist China's Ambassador to Thailand), he concluded secret consular agreements with both countries. In addition, he devalued-against the NLH's opposition- the kip, made an agreement with Japan on technical and economic aid amounting to one billion yen (about $\$ 2.8$ million) and showed an enthusiastic interest in the Mekong River project. 
The Chinese evidently regarded Phoui Sananikone's extreme antiCommunist policy as inconsistent with the political requirements for Laos' domestic harmony and neutral foreign policy. In the latter half of 1958, however, the Chinese conspicuously failed to respond to such unfavorable developments as Taiwan's growing influence in Vientiane. Indeed, they made fewer and fewer public reports or comments on Laos. They were possibly preoccupied with a number of external problems other than Laos which were more vital to their over-all strategic considerations. The landing of U.S. marines in Lebanon in July, a threat to a new revolutionary regime in Iraq, intensified the disagreement between Moscow and Peking over the Middle East situation. Even though the Chinese urged Moscow to take vigorous military action, Premier Khrushchev appealed for a peaceful solution of the crisis among major world powers without China and even accepted a Western proposal for a Security Council discussion of the question. This example shows that Moscow and Peking were drifting apart in certain strategic and diplomatic questions. On August 23, 1958-twenty days after Khrushchev visited Peking and five days after Phoui Sananikone became premier of Laos-the Chinese started their heavy artillery barrage on the Quemoy Islands. Although Chou En-lai's proposal for the resumption of Sino-American ambassadorial talks partly relieved the crisis, the Chinese kept up the pressure on the Islands throughout 1958. Internally they were occupied with the problem of people's communes. By comparison the question of Laos appeared relatively unimportant.

In January, 1959, Phoui Sananikone took further steps to consolidate his anti-Communist position. He obtained from the National Assembly a special mandate to rule for one year without reference to the legislature, to implement an anti-Communist program, and to cancel the general elections for a while. He also strengthened the government with more members from the Army and the CDNI, including Col. Phoumi Nosavan (Secretary for Defense). ${ }^{14}$ He justified these measures by alleging that North Vietnamese troops had infiltrated the area north of Tchepone near the boundary between North and South Vietnam. On January 14, the RLG asked United Nations Secretary-General Dag Hammarskjold to circulate among all U.N. members its report that "armed elements" of the Democratic Republic of Vietnam had 
been occupying some Lao villages since December, $1958 .^{15}$ It did not request a meeting of the Security Council or an observation mission from the U.N. although the Laotian Ambassador to Thailand suggested such a step.

On the other hand North Vietnam accused Laos of conducting a series of air and ground intrusions into its territory under U.S. instigation and proposed reconvening the International Commission to deal with this question. This border dispute, coupled with the Pathet Lao question, had continuously plagued the relationship between Laos and North Vietnam. Fearing that the United States might use the dispute as a "pretext for intervention" into Laos, the Chinese advised Laos to settle it by negotiations with North Vietnam. ${ }^{16}$ At the same time they warned against "some extreme pro-American elements" in Laos who had created conflict in Indo-China by asking for SEATO's protection. Two weeks later the Chinese accused the United States of handing over ten truckloads of weapons and munitions to Laos and of sending 82 Filipinoes to do military construction works in Vientiane. This naked violation of the Geneva agreements, the People's Daily "Observer" declared on February 4, 1959, could not but increase tension in IndoChina and thus arouse his "greatest concern." To counter the close military collaboration between the United States and Laos, the "Observer" appealed to patriotic Laotians: "No Laotian with a sense of national dignity and patriotism will allow this to happen." And he warned: "No one concerned with peace in Indo-China will tolerate this."

But persuasion and threats from Peking and Hanoi only hardened Phoui Sananikone's anti-Communism. On February 11, he declared that all agreements on the cessation of hostilities in Laos had been fulfilled after the May, 1958, elections, thus cancelling the Geneva formula. In response to Communist countries' proposals for revival of the Commission, he made it clear that an independent and sovereign Laos would recognize arbitration only from the United Nations. The following day he issued an explanatory statement to the effect that Laos did not intend to participate in any military alliance "at the present time," nor adhere to a pact inconsistent with the U.N. Charter. ${ }^{17}$ Nonetheless, Laos reserved the right to join any alliance later or even to accept an American military mission. Naturally the U.S., which had 
dissociated itself from the Geneva accords, welcomed Phoui Sananikone's formal renunciation of these agreements. The Geneva provision, in fact, legally barred Laos from a military relationship with any country except France. In recent years, however, a diminishing interest in Indo-China and heavy commitments in Algeria had caused France to reduce its military personnel in Laos to the level of about one thousand men, one-fifth of the total number permitted at the Geneva Conference. In order to make Laos a "bastion of the Free World" in Southeast Asia, the United States therefore felt it necessary to lift the Geneva restraint and assume a direct responsibility for training the Laotian army. For this reason the United States was satisfied with Phoui Sananikone's "realistic" and "courageous" dismissal of the Geneva provisions. ${ }^{18}$

Section Two: Assertive Approaches toward Laos

Phoui Sananikone's bold policy against the status quo envisaged at Geneva gradually aroused extreme anxiety among Hanoi, Moscow, and Peking. As Laos aligned itself with the United States, the Chinese issued strong demands and pursued a variety of tactics in line with their analysis of the rapidly changing circumstances. In a major policy statement on February 18, 1959-a few days after Hanoi and Moscow issued similar statements, Foreign Minister Chen Yi declared that Phoui Sananikone's unilateral declaration of February 11 constituted an "unscrupulous violation of the Geneva agreements" and a part of the U.S. "imperialist plot of aggression against Indo-China."19 $\mathrm{He}$ argued that China, as a participant in the Geneva Conference and a neighbor of Laos, could not help expressing "grave concern" over the U.S. attempt to destroy the Geneva agreements and sabotage the peace in Indo-China. Toward Vientiane too he directed a bitter admonition:

The Royal Laotian Government is fully bound by the Geneva agreements. It has the duty and obligation of implementing seriously and completely the various decisions of the Geneva Conference concerning the Laotian question. The Chinese Government firmly opposes the unilateral tearing up of the Geneva agreements by the Royal Laotian Government. The Royal Laotian Government must bear all the consequences arising therefrom.

As a means of diplomatic pressure against Vientiane and Washington, Chen asked the International Commission to resume its duties in Laos and requested the Geneva Conference Co-chairmen to take "speedy action" against possible American military intervention in the country. 
But the proposal for reviving the Commission failed to gain strong support from its Indian Chairman, who said India could not reconvene it unless the RLG so requested.

The Chinese regarded the steady flow of war materiel into Laos as evidence of America's determination to transform Laos into a military base. And they interpreted the concomitant attempt to make SEATO directly responsible for the defense of Laos as disruptive of the existing distribution of power in Indo-China and as a threat to their own security. The seriousness with which China reacted to these developments was probably calculated to present an advance warning to SEATO strategists. For the purpose of demonstrating collaboration between Laos and SEATO, China compiled a list of various "evidences." For instance, General Ouan Rathikoun, Laotian Army Chief-of-Staff, expressed his willingness to accept SEATO's protection and even demanded its intervention in the border conflict with North Vietnam. Again, Admiral Harry D. Felt, Commander-in-Chief, U.S. Pacific Forces (CINPAC), visited Laos during his three-month tour of Southeast Asian countries. And, finally, Laos, together with Taiwan, South Vietnam, and South Korea, sent a delegation to observe the AmericanThai military maneuvers in northern Thailand. ${ }^{20}$

The Chinese were also irritated by SEATO's practice of holding maneuvers-including an action in February involving nuclear weapons -against a hypothetical Chinese enemy. "This display of military might," Peking Review indignantly asserted on March 10, 1959, "is meant to intimidate the countries of Indo-China and drag them into the SEATO bloc ... and to convert these countries into bases for military provocations against People's China, the Democratic Republic of Vietnam and other peace-loving countries of Southeast Asia." The Chinese objected especially to what they termed a system of anti-Communist military barriers crisscrossing Laos, Thailand, and South Vietnam. They discerned such a system in the formation of a "tripartite military alliance" among these three states, the construction of a strategic highway across the Indochinese Peninsula, and the establishment of a U.S. military base in Lower Laos.

No problem arising from these situations in Southeast Asia affected China's border security and diplomatic status more directly than the growing influence of Taiwan in Laos and the presence of Kuomintang 
irregular forces in the rugged area along the Sino-Laotian border. The fact that Laos concluded consular agreements with Taiwan in December, 1958, and received a Nationalist Chinese consulate in Vientiane in January, 1959, was a decisive setback to Peking's long diplomatic overtures toward Laos. The CPR, always extremely conscious of anything that ignored its claim for international recognition as the only lawful government of China, angrily denounced what People's Daily (February 19,1959 ) called a "most unfriendly act of deliberate provocation by the Royal Laotian Government against the Chinese people." The consular relations enabled Taiwan to promote economic and technical cooperation with Laos and even to exercise a supervisory role over Overseas Chinese communities. After Phoui Sananikone's anti-Communist campaign expelled suspected Communist teachers from Chinese schools in Laos, the Nationalist Chinese Consulate supplied a few instructors from Taiwan with a view of controlling the Overseas Chinese educational system as well. ${ }^{21}$

TABLE 3

Overseas Chinese in Indo-China: 1959-60ª

(In Thousands)

\begin{tabular}{|c|c|c|c|}
\hline Country & $\begin{array}{l}\text { Overseas } \\
\text { Chinese }\end{array}$ & $\begin{array}{c}\text { Total } \\
\text { Population }\end{array}$ & $\begin{array}{c}\text { Overseas Chinese/ } \\
\text { Total Population } \\
(\%)\end{array}$ \\
\hline Laos & 35 & 1,805 & 1.9 \\
\hline Cambodia & 350 & 5,347 & 6.5 \\
\hline 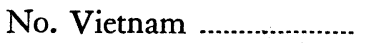 & 55 & 15,916 & 0.3 \\
\hline 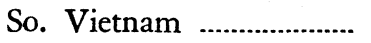 & 800 & 14,214 & 5.6 \\
\hline
\end{tabular}

"Source: Victor Purcell, The Chinese in Southeast Asia (London: Oxford University Press, Second Edition, 1965).

Although the Overseas Chinese were numerically insignificant in the multi-ethnic milieu of Laos, they played an important commercial and financial role in the urban areas where they were principally concentrated. With a strong sense of ethnic superiority they preserved their cultural identity with their fatherland by using their own language, customs, temples, and schools. The economic power and industriousness of the Chinese created a fear and jealousy among the Laotians, but also generated a sense of envy and respect toward the Chinese. It was to Peking's obvious political disadvantage that Taiwan pene- 
trated the Overseas Chinese communities-a potentially useful instrument of Peking's policy toward Laos.

But the presence of KMT irregulars near the Sino-Laotian border was a more urgent problem for Peking, particulary because there were signs of political unrest in Yunnan Province which was separated from the mainstream of Chinese life by geographic distance and ethnic differentiation. The Chinese claimed that the precipitous increase in the activities of Kuomintang forces was made possible by an AmericanLaotian scheme to carry out military provocations against China. This was the first time the Chinese had raised the issue publicly, though they had been concerned with the movement of these forces from Burma to Laos for some time. The United States, China asserted, had instigated these activities; both American and Laotian aircraft had dropped arms and provisions to KMT forces, carried out low-altitude reconnaissance flights over southern China, frequently violated China's air space, and created "disturbances" within the Chinese border. In its most bitter accusation Peking alleged in March, 1959:

Using Thailand and South Vietnam as its bases, the United States is trying to put Laos completely under its control, to subvert the Royal Government of Cambodia and encircle the Democratic Republic of Vietnam in order to seize the whole of the Indochina peninsula, threaten the peaceful and neutral countries in Southeast Asia and menace the southern borders of China. ${ }^{22}$

Furthermore, Peking insisted that Laotian military authorities, having reached a secret agreement with Taiwan in December, 1958, were assisting the KMT's secret agents in collecting information, spreading rumors, and instigating riots in Yunnan Province. Serious warning was given that if the RLG continued to disrespect the principles of peaceful coexistence and the Sino-Laotian agreement, it must accept the "grave consequences" arising from its hostile actions. This warning even implied that Peking might exercise the right to liquidate this border harassment just as it had eliminated a similar problem along its Burmese border. But subsequent events suggest that the Chinese exaggerated the border question to influence the direction of Laotian policy as a whole. By overstating their concern, the Chinese hoped to deter Laos and America from accelerating their anti-Communist actions both inside and outside Laos. Peking also stressed the issue of KMT troops in Laos as a means of recalling the International Commission. 
The use of China's diplomatic and psychological pressures upon Laos from February to May, 1959, was intended to frustrate the program of political and military coordination which America was organizing with Laos, Thailand, and South Vietnam, and to restore the legitimacy of the Geneva and Vientiane agreements in Laos without encouraging the Pathet Lao to direct military action. The revival of these agreements as the basic ground rules of the Laotian question could bring several advantages to the Chinese: the provision of a legal basis for their legitimate concern over Laos; the reactivation of the International Commission as a diplomatic deterrent to America's and SEATO's progressive military commitments; and the reopening of the way to a coalition government with NLH participation. But, by limiting themselves to diplomatic and psychological methods, the Chinese revealed their hesitation about getting involved in the Laotian turmoil. It is therefore evident that the leftward swing of China's general foreign policy-manifested in its attitudes toward Taiwan in 1958, and India in 1959-had not yet involved her Laotian policy by early 1959 .

The continuation of China's verbal militancy merely encouraged Premier Phoui Sananikone to heighten his anti-Communist activities. Upsetting China's expectations, he introduced a measure to destroy the foundation of the Pathet Lao's political power. In May, 1959, he ordered the two remaining ex-Pathet Lao battalions (totalling 1,500 men) disarmed. These battalions had been allowed to retain their own command structure pending complete integration into the Royal Army but had been unwilling to receive the ranks offered by the RLG. The first battalion stationed near Luang Prabang reluctantly accepted this order, but the second battalion in the Plain of Jars defied it and successfully escaped the cordon of the heavily-armed government troops. As soon as the battalion completed a "Long March" close to the North Vietnamese border, it recruited former Pathet Lao soldiers and frontier minorities and launched a counter-attack against Vientiane with the assistance of Hanoi's political cadres and military personnel.

The RLG claimed that the Pathet Lao leaders, determined all along to renew armed resistance, had preserved many hidden stores of weapons and sent several hundred officers and youth to North Vietnam and China for military training and political indoctrination. From the time the Pathet Lao voluntarily surrendered about 5,000 weapons in Feb- 
ruary, 1958, the Royal Army and police had reportedly seized within one year a great number of Pathet Lao's hidden arms. ${ }^{23}$ Nevertheless, although Prince Souphanouvong, Phoumi Vongvichit, Nouhak Phoumsavan, Sithone Komadam, Phoun Sipraseuth, Col. Singkapo, and other $\mathrm{NLH}$ leaders were placed under house arrest in Vientiane in May and later in July charged with offenses against the security of the State, the dissident Pathet Lao forces were led by four other leaders-Faydang (NLH's Vice-Chairman), Kaysone Phoumvihan (ex-Pathet Lao commander), Souk Vongsak (member of the National Assembly), and Khamtay Siphandone (NLH's spokesman).$^{24}$

The possibility of large-scale armed hostilities near North Vietnam and China was so grave that China formulated a new set of concepts and tactics toward Laos. As their diplomatic and psychological methods failed, the Chinese assumed an assertive policy to assist the Pathet Lao's rebellion and to bring militant pressure upon Vientiane. Perhaps this shift was more an inevitable reaction to the initiatives of Vientiane than a conscious application of a radical policy. In a Foreign Ministry statement the Chinese caustically noted that Phoui Sananikone's efforts to liquidate the two ex-Pathet Lao battalions and to persecute the NLH leaders were even more serious than his repudiation of the Geneva accords and were tantamount to making "civil war" in Laos. ${ }^{25}$ Should he continue to act on behalf of America's aggressive plot in IndoChina, they said, he would be held responsible for all the ensuing grave consequences and critical problems. And an unmistakable warning was given that China could not look on with indifference at the serious actions taken by Vientiane.

While asking the Geneva Co-chairmen to reconvene the International Commission in Laos, the Chinese also condemned the rapid increase in Vientiane's contacts with South Vietnam and Thailand. During May, Laotian Foreign Minister Khamphan Panya visited Saigon for political and military consultations and concluded with South Vietnam an agreement of commerce and friendship which emphasized the need to "consolidate their position in the face of the Communist threat." $\mathrm{He}$ also met with Thai Foreign Minister Thanat Khoman in Vientiane; a joint statement declared that Laos had the right to join any international or regional organization. ${ }^{26}$ The United States publicly endorsed Phoui Sananikone's anti-Communist stand and let it be known that the tension 
in Southeast Asia had arisen from China's "infiltration, subversion and threats of hostile military actions." In the face of the confusing situation in Laos and the criticism raised both by Communist countries and by Congress, the U.S. Government admitted that the "favorable developments" in Laos could not have succeeded without American material support. The Government described its objectives as assisting Laos to prevent a Communist takeover, to strengthen its association with the free world, and to develop and maintain a stable and independent government, willing and able to resist Communist aggression and subversion. ${ }^{27}$

These American objectives, well within reach by May and July, constituted a serious threat to Chinese interests-including national security -in Laos. China could hardly accept the total collapse of the Pathet Lao movement and the approach toward their border of hostile Laotian forces supported and controlled by the United States. Once convinced that diplomatic and persuasive tactics were futile and that only a successful military counteroffensive by the Pathet Lao could reverse the unfavorable course of events in Laos, the Chinese, in close cooperation with Hanoi, undertook to strengthen the Pathet Lao's fighting capabilities. They apparently provided the Pathet Lao with military aid, strategic advice, and personnel support, set up a center for training Pathet Lao cadres at Sze-mao in Yunnan Province, and sent into Laos Chinese cadres of the Ho tribe-"brothers" of the Ho tribesmen living in northern Laos. ${ }^{28}$ They also allowed the Pathet Lao to use Radio Peking for disseminating anti-Vientiane propaganda. The deepening involvement of China in Laos prompted the RLG to complain to the United Nations: "A rebel aid committee has been set up at Hanoi, with the task of receiving arms and munitions arriving from the People's Republic of China and of providing the rebels with logistic support, clothing, medical supplies, etc." ${ }^{29}$ No doubt the coordinated assistance programs of China and North Vietnam, coupled with the limited commitments of North Vietnamese troops in Laos, contributed in no small way to the Pathet Lao's prolonged resistance against Vientiane's military drive.

As the Pathet Lao were accepting vital assistance from China and North Vietnam, the RLG was stepping up its anti-Communist crusade in various ways. First, Laos and France reached an arrangement enabling the United States to give emergency aid to the Royal Army and 
train it with American specialists and technicians. Second, Laos and America agreed to expand the Royal Army from 25,000 to 29,000; these troops would oppose Pathet Lao field forces estimated at about 2,000, but assisted by North Vietnamese troops estimated to number somewhere between several hundreds to several thousands. As People's Daily (July 27) correctly pointed out, the Franco-Laotian arrangement in effect "legalized" America's function of providing financial support, material supplies, advice, and training for the Royal Army. In reply to a Communist charge that the United States was turning Laos into a military base threatening the security of China and North Vietnam, the State Department categorically denied the existence of American military bases, airstrips, or other military installations in Laos. ${ }^{30}$ But it acknowledged the U.S. role in helping Laos strengthen its defensive positions, increase its army and village militia, and improve its military mobility.

We should note here that China's assistance to the Pathet Lao struggle was essentially limited both in its objective and in its extent. The objective was not the Pathet Lao's total conquest of Laos. Surely the small size of Pathet Lao forces-less than one-tenth of the Royal Army-prohibited such a feat. Moreover, North Vietnam's massive military participation in such an attempt was neither possible nor desirable from the Chinese point of view. China hoped to sustain a limited civil war in northern Laos to help obtain a political goal-namely, restoration within the framework of Geneva and Vientiane agreements of the status quo ante July, 1958, when the International Commission had adjourned and the coalition formula had collapsed. In view of increasingly unreliable military and nuclear relations with Moscow at this period, the Chinese could not risk escalating a local war into a major international conflict which might lead to their own military involvement and to massive retaliation from the United States. In the middle of 1959, Moscow refused to provide China with a sample atomic bomb and technical data concerning its manufacture or to fulfill the agreement on new technology for national defense concluded between both countries in October, $1957 . .^{31}$

China's assertive policy toward Laos was thus designed, among other things, to utilize effectively the threat of a wider war and to create circumstances in which the Pathet Lao could acquire enough 
leverage to negotiate on equal terms with Vientiane. China's military assistance, diplomatic pressure, and exaggeration of the Kuomintang question-all contributed to this goal. To achieve it, the Chinese presented four terms for peaceful solution of the Laotian question in a Foreign Ministry statement on August 12, 1959:

(1) the United States and the Sananikone government cease their activities against the Geneva and Vientiane agreements; (2) withdraw all American military personnel, arms and ammunition from Laos and scrap all American military bases in that country; (3) the normal control and supervision functions of the International Commission are resumed; and (4) the Geneva and Vientiane agreements are thoroughly implemented. ${ }^{32}$

But none of these demands was acceptable or even negotiable in the eyes of Vientiane and Washington, which were more interested in destroying the Pathet Lao forces than in establishing a dialogue with these "armed rebels" backed by Hanoi and Peking.

In the midst of the crisis, moreover, the Geneva Co-chairmen failed to reactivate the International Commission or take any "speedy" or "necessary" measures against Vientiane and Washington as requested by Peking. During the Geneva Conference of Foreign Ministers in June, Andrei Gromyko and Selwyn Lloyd held talks on Laos but produced nothing more than a number of vaguely worded appeals for restoration of peace in Laos. While Britain held the view that the actions of the United States and the Laotian Kingdom constituted no violation of Geneva and Vientiane agreements, the Soviet Union offered less than full support for the Pathet Lao's military efforts. Premier Khrushchev was prone to discourage militant struggle by Asian Communists inspired by China as disruptive of his policy of peaceful coexistence. His priority of peaceful coexistence militated against the violent methods of national liberation movements in favor of improving SovietAmerican relations. For this purpose, during July and August, he anxiously solicited and received an invitation to visit the United States in the fall of 1959.

Section Three: The United Nations Presence and Its Effects

In order to realize their primary political objective of reinstating the Geneva and Vientiane agreements in Laos, the Chinese persistently opposed the introduction of any new formula or instrument. The possibility that SEATO or the United Nations might involve itself in 
the Laotian crisis annoyed the Chinese. Since they were not directly represented in the United Nations or in any regional organization, the Chinese were wary of any regional or international groups trying to interfere in Laos, a situation which would exclude their voice and participation. Ignoring the Chinese concern, the RLG took a series of steps which gradually brought the United Nations into Laos. In August, it brought to Hammarskjold's attention acts of aggression and frontier violations by North Vietnam and instructed Ambassador Ngone Sananikone to consult with Hammarskjold for the purpose of finding ways and means of restoring peace to Laos. As there were reports of severe North Vietnamese attacks against the Royal Army posts in the northern provinces of Sam Neua and Phong Saly at the end of August, Foreign Minister Khamphan Panya sent to the Secretary-General a telegram in which he claimed: "Elements from the Democratic Republic of Vietnam took part in the attack, which was supported by artillery fired from the other side of the frontier." ${ }^{33} \mathrm{He}$ requested that "an emergency force should be dispatched at a very early date in order to halt the aggression and prevent it from spreading."

The wording of this complaint could easily be interpreted in line with the phrase "aggression by means of armed attack" as defined in Article 4 of the SEATO Treaty; despite this possibility, the protective obligations assumed by SEATO members were not invoked for Laos. SEATO's inaction seemed to rest on a number of political considerations. First, the members disagreed about the desireability of collective military action, a course opposed by Britain and France. Second, they realized that action might provoke retaliation from China and North Vietnam. And, finally, they judged that the U.N. could contain the Communist military pressure more safely and effectively than SEATO. Although it preferred local military action to check the Pathet Lao, the United States supported the Laotian request for the U.N. "emergency force." At the same time the State Department accused Peking and Moscow of plotting with Hanoi to invade Laos. It added a stern warning:

It is obvious that any further augmentation of the invading force or continued material support thereof by Communists in North Vietnam will require a major change in the nature and magnitude of the Royal Lao Government's need for support. The United States is confident that the free world would recognize such a new danger to peace and would take the action necessary. For its part, the United States supports that view. ${ }^{34}$ 
On the basis of Kamphan Panya's message the Secretary-General requested an urgent meeting of the Security Council to consider the crisis. The United States, Britain, and France submitted a draft resolution to appoint a Sub-Committee consisting of Argentina, Italy, Japan, and Tunisia. Its function was "to examine the statements made before the Security Council concerning Laos, to receive further statements and documents and to conduct such inquiries as it may determine necessary, and to report to the Council as soon as possible." ${ }^{35}$ When Mr. Sobolev of Russia raised the preliminary question of whether such a draft resolution was procedural, the Council voted 10 to 1 (Russia) in favor of its procedural nature. After the Council President declared the draft resolution a procedural matter, the resolution itself was passed by a vote of 10 to 1, again Russia alone opposing the measure.

The legal basis of this Security Council Sub-Committee became a subject of controversy. The Soviet Government called the Sub-Committee illegal on the ground that the preliminary question raised by Sobolev required an affirmative vote of more than seven members, including all the permanent members, and that the decision on the SubCommittee as an "investigatory body" was a substantive matter requiring the same qualified majority. Even though the Western powers did not reject the applicability of double veto power, they argued that the President's declaration stood unless overruled by the Council. ${ }^{36}$ They also said it was a procedural matter to set up the Sub-Committee of "inquiries" as a "subsidiary organ" for the performance of the Council's functions. According to Article 27, it is incontestable that the vote on Sobolev's preliminary question is a substantive matter, while Article 29 shows that the establishment of subsidiary organs is a procedural one. Yet Professor Leo Gross, arguing persuasively that the question of a subsidiary organ of the Security Council must be evaluated in the context of its intended objectives and functions, concludes that, as the Sub-Committee was intended to be a fact-finding or investigating body which ensured a U.N. presence in Laos, it can scarcely be regarded as a mere procedural matter. ${ }^{37}$

These legal controversies attracted little attention or analysis from China. As Professor Hungdah Chiu suggests, the Chinese tend to consider international legal questions as instruments of politics. ${ }^{38}$ Likewise, they were more concerned with the political consequences arising 
from the Sub-Committee's functions than with its legal trappings. The Sub-Committee appeared to them an American instrument to legalize and engineer a new conspiracy in Laos. It would only handicap their own assertive policy in that country and, more importantly, introduce into the Laotian scene a new set of rules and procedures which would replace the Geneva and Vientiane agreements. The eclipse of the Geneva agreements would deprive the Chinese of a convenient legal ground for justifying their "sacred" and "legitimate" international obligations regarding Laos. It must have disturbed the Chinese to realize that the Soviet Union-as the Pathet Lao's U.N. spokesmanwould gain influence over the movement, or that the Soviet Union might very well compromise the Pathet Lao's cause for the sake of its détente with the United States.

Thus, Chen Yi stated: "The United Nations has no right whatsoever to meddle in the Laotian situation. Any attempt to use the U.N. to interfere in the Laotian question will only aggravate tension in this area and is unfavorable to a solution of that question." 39 In an attempt to offset the Sub-Committee's role, the Chinese endorsed the Soviet proposal for a reconvocation of the Geneva Conference on Indo-China to consider the situation that had arisen in Laos. ${ }^{40}$ Once again they asked the Geneva Co-chairmen and the Indian Government to recall the International Commission so that a new international meeting could receive its reports and recommendations. By this diplomatic maneuver the Chinese admitted that their policy of assertive pressure had failed; thus, they sought to reorient their policy in line with the idea of another conference on Laos. But the Western powers were definitely unwilling to consider that idea, at least until they saw the results of the Sub-Committee's fact-finding mission. This line of reasoning was reflected in a communique announced by the SEATO Council, in which it supported the Security Council's decisions in response to the Laotian question. ${ }^{41}$.

At the invitation of the RLG the U.N. Sub-Committee conducted a fact-finding "inquiry" in Laos from September to October; among other things, it received statements and documents from the Laotian Liaison Committee, interviewed the witnesses summoned by the RLG, and took field trips to places like Sam Neua and Luang Prabang. Strictly confined by its mandate to a factual account of the situation, 
the Sub-Committee refrained from steps designed to influence the course of events in Laos and from conclusions or judgments on the validity of Khamphan Panya's substantive charge. In its report submitted to the Security Council on November 4, the Sub-Committee said that military actions had taken the characteristics of guerrilla activity scattered almost throughout the Kingdom, but with a relatively small number of total casualties. ${ }^{42}$

TABLE 4

Total Casualties in Laos: July-October, 1959a

\begin{tabular}{|c|c|c|c|c|}
\hline & \multicolumn{2}{|c|}{ Royal Army } & \multicolumn{2}{|c|}{ Pathet Lao } \\
\hline & $\begin{array}{l}\text { July } 18- \\
\text { Sept. } 12 \\
\end{array}$ & $\begin{array}{c}\text { Sept. } 12- \\
\text { Oct. } 11 \\
\end{array}$ & $\begin{array}{l}\text { July 18- } \\
\text { Sept. } 12 \\
\end{array}$ & $\begin{array}{l}\text { Sept. 12- } \\
\text { Oct. 11 }\end{array}$ \\
\hline Dead .............. & 80 & 19 & 250 & 150 \\
\hline 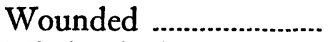 & 56 & 40 & 70 & $\ldots . .$. \\
\hline Missing/Prisoners ....... & 120 & 5 & 7 & 25 \\
\hline Total & 256 & 64 & 327 & 175 \\
\hline
\end{tabular}

a Source: United Nations Security Council Official Records: Fourteenth Year, Supplement For October, November and December 1959 (New York: U.N., 1960).

On the basis of witnesses' declarations it was established that the Pathet Lao forces had received such support from North Vietnam as "equipment, arms, ammunition, supplies, and ... political cadres." But, the report concluded:

The body of information submitted to the Sub-Committee did not clearly establish whether there were crossings of the frontier by regular troops of the Democratic Republic of Viet-Nam.

This inconclusive finding failed to substantiate the central elements of the Laotian charge against North Vietnam and consequently obscured any legal basis for discussing the request of a United Nations "emergency force" to be sent to Laos.

The Sub-Committee's report incidentally showed some "evidences" of such Chinese material assistance to the Pathet Lao forces as rifles and submachine-guns, hand grenades, uniforms, and medical supplies. China, however, officially dismissed these evidences of its role as minor and dubious. Although they raised many objections to the Sub-Committee's "illegal" functions, the Chinese quickly seized on its report to suggest that Vientiane and Washington had fabricated the story concerning North Vietnam's aggression into Laos. On November 7, a 
Hsinhua News commentator was authorized to state that the Sub-Committee's report drove home the point that "U.S. imperialism used it to cover its own interference and creation of tension in Indo-China." In view of the widespread news indicating the possibility of the United Nations' continuous involvement in Laos, the commentator said that the United States was plotting to set up some kind of United Nations permanent office in that country and use it for her interventionist intentions.

Notwithstanding its inconclusive report the Sub-Committee did help to relieve the tension-fraught situation in Laos. After the SubCommittee's arrival at Vientiane on September 15, there appeared signs of substantial reduction in the Pathet Lao's military activities and in the assistance given to them by Hanoi and Peking. The Sub-Committee's brief but watchful presence served as a kind of diplomatic buffer to protect Laos from the effects of the Pathet Lao's military campaign and from the pressures of its powerful Communist neighbors. This led to a state of military stalemate and controlled crisis in Laos during the winter of 1959, and afterwards. A significant contribution to the relaxation of Laotian conflict was also made by Khrushchev's peaceful gestures, which restrained or at least neutralized Peking's and Hanoi's militant pressure over Laos. One day before the beginning of Khrushchev's good-will visit to the United States and, coincidentally, of the Sub-Committee's operations in Laos, the Soviet Government issued a statement regretting that "certain circles" among the Western powers expected the Sub-Committee to poison the international atmosphere at a time "when, because of the forthcoming exchange of visits between the heads of government of the Soviet Union and the United States, all mankind looks hopefully for an end of the "cold war." "43 During his stay in America, Khrushchev emphasized the importance of peaceful coexistence in the world community and the possibility of eliminating both "cold" and "hot" wars. At the conclusion of talks at Camp David, Khrushchev and Eisenhower agreed that "all outstanding international questions should be settled not by the application of force but by peaceful means through negotiation." ${ }^{44}$ Khrushchev was aware of the need to "sell" his Asian comrades, especially the suspicious Mao Tse-tung and Ho Chi Minh, on this Camp David "spirit." It is also likely that 
Khrushchev attempted to restrain the Pathet Lao's military activities by every available means.

As soon as he returned to Russia, Khrushchev left for Peking for the tenth anniversary of the Chinese People's Republic. His main message to the Chinese leaders was the relaxation of tense relations with the United States. On October 1, 1959, he openly advised China not to test the stability of the capitalist system by force, but to recognize that "we on our part must do all we can to exclude war as a means of settling disputed questions, and settle these questions by negotiations." ${ }^{.45}$ As his thesis indirectly condemned their assertive policy toward India and Laos, the Chinese adamantly refused to accept it at face value. They were especially opposed to the notion that imperialism had changed its aggressive nature in the nuclear age and that the promotion of EastWest reconciliation should be given precedence over the support for national liberation struggles. This serious disagreement on the problems of world-wide revolutionary strategy and tactics prevented Mao and Khrushchev from issuing even a customary joint statement.

In a report to the Supreme Soviet at the end of October, Khrushchev, still mindful of the danger in the Laotian situation, made it clear that the Soviet Union opposed the "existence of even the smallest source of war in Laos which could give food to the aggressive forces." ${ }^{\text {"6 }}$ He hoped that a "sensible approach"-not the militant one advocated by Pekingwould eliminate the armed conflict in Laos. The Chinese, perhaps intent on countering Khrushchev's optimism, publicized and criticized the continued persecution of the NLH leaders. In a letter to Gromyko and Lloyd on the same day that Khrushchev reported to the Supreme Soviet, Chen Yi called for immediate "emergency measures" to prevent Premier Phoui Sananikone's planned trial of the NLH leaders. ${ }^{47}$ This was accompanied by a series of mass rallies and declarations sponsored by China's various "people's organizations" to protest the trial. In early November, Kuo Mo-jo, Chairman of the Chinese People's Peace Committee, declared that the trial was a "new plot worked out by U.S. imperialism to instigate the Sananikone clique to further destroy the Geneva and Vientiane agreements and expand the civil war in Laos." ${ }^{38}$

Even though Khrushchev proved unable to moderate China's attitude toward Laos, his efforts seem to have contributed to restraining the militant stance of North Vietnam and the Pathet Lao to some extent. 
Perhaps in response to his prodding, the NLH Central Committee, in a small conciliatory gesture toward Vientiane, sent a letter to the Geneva Co-chairmen in November, proposing "peaceful negotiations" with the RLG. However, its provisions were difficult. They called for the convocation of a second Geneva Conference, the cessation of the civil war, the resumption of the International Commission's functions, the release of political prisoners, and the withdrawal of U.N. representatives from Laos. ${ }^{49}$

In the meantime Secretary-General Hammarskjold took further steps to extend the United Nations' role in Laos. On November 10, he visited Vientiane in search of "independent and full personal knowledge of the Laotian situation." Soon thereafter, he appointed Sakari Tuomioja, Executive Secretary of the United Nations Economic Mission in Europe, as his "personal representative" entrusted to review economic conditions in Laos and determine what U.N. assistance it required. ${ }^{50}$ The Secretary-General used a personal representative in order to bypass a procedural difficulty which Soviet veto would create in any attempt to authorize formally a U.N. mission to Laos. But Hammarskjold could not avoid a barrage of bitter accusations from the Communists.

While the Soviet Union contended that since the Sub-Committee's report failed to verify the RLG's complaint, the case should be closed, the North Vietnamese Foreign Ministry and the NLH Central Committee denounced Tuomioja's representation as "illegal and invalid." More scathing was a Chinese criticism that, by abusing his prerogatives and meddling in the internal affairs of Laos, Hammarskjold served as a "tool of the vicious conspiracy of the United States and the Sananikone government." ${ }^{\text {.52 }}$ The Chinese argued that his visit to Laos and his appointment of a U.N. representative, which supplanted the Geneva and Vientiane agreements and ruled out a possible resumption of the International Commission, encouraged Washington and Vientiane in "persecuting and slaughtering the Laotian people and extending the civil war there."

These Communist pressures did not deter Hammarskjold from preserving a kind of U.N. presence in Laos. After Tuomioja in December presented his recommendations for assisting Laos, Hammarskjold sent to Vientiane another U.N. representative, Roberto Heurtematte (Commissioner of the U.N. Technical Assistance Program), with in- 
structions to study ways of implementing Tuomioja's recommendations. The Secretary-General also was planning to create a permanent mission to include and coordinate all U.N. specialized agencies in Laos. Indisputably Hammarskjold's personal commitments helped to relax the crisis in Laos and organized a number of U.N. technical assistance programs to that country. Overwhelmed by the U.N.'s prestige in Laos, Edwin F. Stanton even suggested that careful parliamentary tactics and skillful diplomacy, as practiced by Hammarskjold, could enhance the U.N. authority in spite of big power politics. He concluded: "A Secretary-General with initiative, ability and wisdom can, in his official and personal capacity, take rapid and effective measures without necessarily referring such measures either to the Security Council or the General Assembly." ${ }^{53}$ There arises, however, a legitimate counter-argument that cold-war issues like Laos are too intractable to yield to parliamentary diplomacy and that a Secretary-General's personal initiatives, exercised without the U.N.'s proper authorization, may jeopardize his general status as an impartial leader of the United Nations. ${ }^{54}$

When the Royal Army and the CDNI, disillusioned with Phoui Sananikone's domestic and foreign policies, staged a coup d'état at the end of 1959, Hammarskjold, together with U.S. Ambassador Horace Smith, was quick to intervene in the political turmoil and denounce the coup. In a message from the Congo, he advised King Savang Vatthana to restore political harmony and maintain a neutral foreign policy. $\mathrm{He}$ noted that the United Nations was now directing attention to Laos, and that the U.N. presence had helped to quiet Communist belligerence. ${ }^{55}$ On the following day the coup leaders agreed to accept a caretaker government under Premier Kou Abhay, respectable President of the King's Council, until the forthcoming general elections; still they retained control in Vientiane through Brigadiar General Phoumi Nosavan.

But Peking and Hanoi reacted differently toward Kou Abhay's new government. While People's Daily (January 8) and Radio Peking (January 11) bitterly denounced it as a "fascist and military dictatorship" controlled by "warlords" and "warmongers," Premier Pham Van Dong sent a conciliatory message to Kou Abhay, expressing his hope that the new government would implement the Geneva agreements on Laos and take measures to improve good neighborly relations between 
the two countries. ${ }^{56}$ As Phoumi Nosavan accelerated the mopping-up operations against the Pathet Lao forces, the Chinese warned against his policy. Not only did they condemn the "attempt" by Vientiane and Washington to eliminate the "patriotic and democratic forces" in Laos, they also declared their resolve to fight "U.S. imperialist adventures to extend the civil war in Laos." ${ }^{.57}$ As the Chinese viewed Phoumi Nosavan's military campaign from the broad perspective of Sino-American strategic tensions, they must have been pessimistic about the relaxation of the Laotian situation and the value of the forthcoming general elections for the Pathet Lao's revolutionary strategy.

Nevertheless, the Pathet Lao leaders, along with Moscow and Hanoi, expressed their willingness to abide by the elections. As soon as the royal order for the elections was issued, the NLH Central Committee proposed negotiations with the RLG to arrange for immediate release of political prisoners and free and democratic elections. It also appealed to the Geneva Co-chairmen to take effective measures guaranteeing the security and freedom of the elections. ${ }^{58}$ But the new electoral law was obviously directed against the Pathet Lao, and the fact that most of Pathet Lao's top leaders were imprisoned or considered "rebels" limited its candidates to 9 for 59 seats contested. ${ }^{59}$ Presumably the Pathet Lao took part in this unfair election only to demonstrate a conciliatory attitude toward Vientiane and thus gain the release of certain Pathet Lao prisoners. In order to counter the RLG's propaganda that the Pathet Lao was an agent of foreign Communist countries, the NLH Central Committee pledged its loyalty to the Kingdom and promised not to obstruct a free election. These Pathet Lao efforts were consistently supported by North Vietnam and Russia, both of which used their diplomacy to guarantee fair elections. ${ }^{60}$

The Chinese not only declined to join Moscow and Hanoi in support of the Pathet Lao's formal electoral participation but indirectly said the elections were a "political farce" manipulated by Vientiane and Washington. For example, Tseng Ho implied, in his People's Daily commentary on March 23, that the Pathet Lao leaders had lost sight of the dual counter-revolutionary tactics of Washington and Vientiane in their preoccupation with the futile elections. He suggested that the United States assumed a number of peace tactics, including the elections, to retrieve its successive setbacks in Laos. Even though the United States 
might pursue "peace tactics," Tseng said, it had never slackened nor modified its "war tactics." His advice was: "As long as the patriotic forces close their ranks, heighten their vigilance, and persist in their struggle, they will certainly be able to turn Laos into a peaceful, independent, unified, democratic, neutral and prosperous country." The accent on struggle and the rigid ideological approach to the Laotian problems undoubtedly reflected the Sino-Soviet ideological conflict developing at that time.

The Chinese theoreticians, denying the Soviet contention that U.S. leaders could be persuaded to agree to peaceful coexistence in the common interest, maintained a rigid ideological posture that imperialism was unchangeably aggressive. With an obvious polemical intention against the illusions of "modern revisionism," Yu Chao-li analyzed the dual tactics of the imperialists:

It is absolutely impermissible for us to mistake certain tactical changes on the part of imperialism for changes in the very nature of imperialism. Imperialism may adopt this or that tactic at different periods, but it will not change its nature, nor will it alter its basic policies. As long as imperialism lasts, it will exert itself to the full to realize its object of plunder by alternately relying principally either on methods of war or "peace."61

Once translated into the specific context of Laos, Yu's exposition simply reinforced Tseng Ho's analysis.

In an election widely rigged by the RLG authorities with the overt support of the U.S. Central Intelligence Agency, the candidates of the Pathet Lao and the Santiphab had no chance. ${ }^{62}$ Now Moscow and Hanoi joined Peking in attacking the CDNI, whose parliamentary wing won 35 seats, leaving 17 to Souvanna Phouma's Rally of the Laotian People and 7 to independents. Hanoi's Nhan Dan (May 6) denounced the election as part of the "perfidious scheme of the U.S. imperialists to use puppet 'national assemblies' in the realization of their aggressive designs." After the election proved the correctness of their ideological position, the Chinese reaffirmed the vicious nature of imperialist tactics and attempted to work out a common approach with North Vietnam toward post-election Laos. During his visit to Hanoi in May, Chou En-lai once again emphasized: "So long as there exists the threat of oppression, exploitation, plunder, and intervention of imperialism against the peoples of the world, the struggle of the peoples against imperialism and its stooges will never end." In a joint statement 
on May 14, 1960, Chou and Pham Van Dong nevertheless expressed the hope of maintaining good-neighbor relations with Laos. ${ }^{63}$ Such relations, it told Vientiane, required four conditions: (1) the release of the NLH leaders headed by Souphanouvong, (2) the resumption of the International Commission's activities, (3) the termination of civil war, and (4) the scrupulous implementation of the Geneva agreements. Compared with the earlier Chinese demands, the joint statement appeared less rigid and more precise, and avoided any provocative attacks on the American military "presence" in Laos. The convocation of another Geneva Conference, proposed by the Soviet Union and supported by China and North Vietnam in 1959, was not even mentioned in the statement, perhaps because both countries considered it unnecessary or impracticable at the time.

The RLG soon had another problem in addition to the renewed policy coordination between Peking and Hanoi; on May 23, Prince Souphanouvong, with fifteen other NLH leaders, escaped from a Vientiane prison. ${ }^{64}$ These sobering internal and external developments prompted new Premier Tiao Somsanith to assume a cautious and circumspect position toward Asian Communists. In his inaugural address at the National Assembly in June, 1960, he pledged to respect the "policy of neutrality" and good neighborliness. Above all he declared: "The Government will respect the principles of the United Nations Charter and the obligations entered into by the Royal Government, including the Geneva agreements." ${ }^{65}$ This officially reversed Phoui Sananikone's unilateral repudiation of the Geneva accords in February, 1959. But this declaration alone did not satisfy the Pathet Lao. Once its leaders regained freedom from prison, the NLH Central Committee issued its most acrimonious statement calling the "new reactionary government" of Tiao Somsanith an instrument of U.S. "imperialism." To hold new general elections and form a coalition government, the Committee proposed negotiations with the RLG within the framework of the Geneva and Vientiane agreements. ${ }^{66}$

On his part, however, Premier Tiao Somsanith learned two wise lessons: that Laos became defenseless when, as in July and August of 1959, its two Communist neighbors directly supported the Pathet Lao's military offensive, and that Laos could not depend for its own survival only upon U.S. military support. The presence of the United Nations 
Sub-Committee in Laos gave its Communist enemies second thoughts about exerting military pressure; but this effect was temporary and regressive despite Hammarskjold's constant efforts. In February, 1960, he appointed Edouard Zellweger, Swiss jurist and diplomat, to succeed Tuomioja as coordinator of U.N. activities in Laos. Although India had influenced Laos' foreign policy from 1954 to 1958, it probably lost much of its prestige in the eyes of Tiao Somsanith after its own helplessness shown in Sino-Indian confrontation. The RLG, assessing with prudence the internal and external circumstances of Laos, contributed to a relative political tranquility and military impasse for three months until another coup d'état in August, 1960.

\section{Notes}

1. His November 17, 1957, address at the auditorium of Moscow University, in People's China (December 16, 1957), p. 44.

2. Fourth Interim Report of the International Commission for Supervision and Control in Laos, May 17, 1957 to May 31, 1958 (London: HMSO, 1958, Cmnd. 541), pp. 81, 95-96.

3. The successful NLH candidates were: Souphanouvong, Phoumi Vongvichit, Nouhak Phoumsavan, Sithone Komadam, Phoun Sipraseuth, Khamphay Boupha, Tiao Souk Vongsak, Sisana Sisane, and Nang Khampheng Boupha.

4. Editorial Department of People's Daily and Red Flag, The Origin and Development of the Differences Between the Leadership of the CPSU and Ourselves (Peking: FLP, 1963), pp. 59-60.

5. Hsinhua News, June 2, 1958.

6. New York Times, May 14, 1958.

7. Laos Information Bulletin, p. 4.

8. Fourth Interim Report, pp. 75, 120.

9. See People's Daily, June 2 and July 14, 1958, and Kwang-ming Daily, June 3, 1958; for Russian and North Vietnamese positions, see People's Daily, May 27, June 1, and June 2, 1958.

10. "Canada and the International Commission in Laos," External Affairs (Ottawa: Canadian Department of External Affairs, September, 1958), pp. 219-221.

11. See Asian Recorder, February 14-20, 1959, pp. 2508-9, and A. M. Halpern and H. B. Fredman, Communist Strategy in Laos (Santa Monica: The Rand Corporation, 1960), p. 16.

12. Mutual Security Program in Laos: Hearings before the Subcommittee on the Far East and the Pacific of the Committee on Foreign Affairs, House of Representatives (Washington: USGPO, 1958), p. 34.

13. Laos Information Bulletin (September-October, 1958), p. 4.

14. New York Times, January 15 and 25, 1959.

15. "Violation of Lao Territory by Armed Forces of North Vietnam," News Release (Washington: Royal Embassy of Laos), January, 1959.

16. People's Daily, January 21, 1959.

17. News Release, op. cit., February 13 and March 2, 1959.

18. See New York Times editorial, February 23, 1959; and Under-Secretary of State Dillon's statement, Comment by the Department of State and ICA on the Report of the House Committee on Government Operations, "United States Aid Operations in Laos" (Washingon: Department of State, 1959), p. 2.

19. Peking Review (February 24, 1959), p. 22.

20. People's Daily editorial, February 19, 1959.

21. See Joel Halpern, The Role of the Chinese in Lao Society (Los Angeles: University of California, 1961), and Douglas P. Murray, "Chinese Education in Southeast Asia," China Quarterly (October-December, 1964), pp. 81-82.

22. Concerning the Situation in Laos (Peking: FLP, 1959), p. 23.

23. Report of the Security Council Sub-Committee established under resolution of 7 September 1959: Document S/4236, in United Nations Security Council Official Records: 
Fourteenth Year, Supplement for October, November and December 1959 (New York: U.N., 1960), p. 71.

24. For these developments regarding the Pathet Lao leadership, see Arthur J. Dommen, Conflict in Laos: The Politics of Neutralization (New York: Praeger, 1964), pp. 121-122, 137. 138 .

25. Peking Review (May 26, 1959), p. 13.

26. See Asian Recorder (July 4-11, 1959), p. 2751, and People's Daily, May 30 and July $18,1959$.

27. Comment by the Department of State and ICA, op. cit., p. 1.

28. For some of these points, see Bernard B. Fall, "Red China's Aims in South Asia," Current History (September, 1962), p. 140.

29. Report of the Security Council Sub-Committee (Document S/4236), op. cit., p. 55.

30. Department of State Bulletin (September 14, 1959), p. 374.

31. See the CPR statement of August 15, 1963, in People of the World Unite, For the Complete, Thorough, Total and Resolute Prohibition and Destruction of Nuclear Weapons! (Peking: FLP, 1963).

32. Peking Review (August 18, 1959), p. 9.

33. Note of 4 September 1959 to the Secretary-General from the Permanent Mission of Laos: Document S/4212, in United Nations Security Council Official Records: Fourteenth Year, Supplement for July, August and September 1959 (New York: U.N., 1960), pp. 7-8.

34. New York Times, September 6, 1959.

35. Report of the Security Council Sub-Committee (Document S/4236), op. cit., p. 12.

36. See the Soviet statement of September 14, 1959 (Document S/4222), and the British note of September 22, 1959 (Document S/4223), in United Nations Security Council Official Records: Fourteenth Year, Supplement for July, August and September 1959, op. cit., pp. 13$18,19-21$.

37. "The Question of Laos and Double Veto in the Security Council," American Journal of International Law (Volume 54, 1960), pp. 118-131.

38. "Communist China's Attitude Toward International Law," American Journal of International Law (Volume 60, 1966), pp. 245-267.

39. Concerning the Situation in Laos, op. cit., p. 75.

40. Peking Review (September 22, 1959), pp. 21-22.

41. New York Times, September 29, 1959; the State Department said that the solution of the Laotian question "is not to be found in international conference but in the cessation of intervention and subversion" by Laotian Communists, New York Times, September 16, 1959.

42. Report of the Security Council Sub-Committee (Document S/4236), op. cit., pp. 10-34.

43. The Soviet statement (Document S/4222), in United Nations Security Council Official Records: Fourteenth Year, Supplement for July, August and September 1959, op. cit., p. 16.

44. Gillian King (ed), Documents on International Affairs 1959 (London: Oxford University Press, 1963), pp. 85-86.

45. Peking Review (October 6, 1959), pp. 7-10.

46. See Donald S. Zagoria, The Sino-Soviet Conflict: 1956-1961 (Princeton: Princeton University Press, 1962), p. 283.

47. Survey of China Mainland Press (Hong Kong: U.S. Consulate-General, November 5, 1959), pp. 51-52.

48. Ibid., November 10, 1959, p. 43.

49. Foreign Broadcast Information Service: Daily Report (December 2, 1959), EEE-2.

50. New York Times, November 16 and 18, 1959; and see Richard I. Miller, Dag Hammarskjold and Crisis Diplomacy (Dobbs Ferry: Oceana Publications, 1961), pp. 233-256.

51. Foreign Broadcast Information Service: Daily Report (November 18 and 27, 1959).

52. Ta-kung-pao, November 21, 1959.

53. "A Presence in Laos," Current History (June, 1960), p. 341.

54. For example, see Leo Gross, op. cit., p. 131.

55. New York Times, January 9, 1960.

56. FBIS: Daily Report (January 15, 1960), EEE-3.

57. People's Daily, January 22, and Ta-kung-pao, January 23, 1960.

58. Hsinhua News, February 10 and 19, 1960.

59. Candidates were required to have high educational backgrounds, long governmental services, or good tax payment records. They also had to prove uninterrupted residence for five years in one place and to make a deposit of $\$ 300$ or more. See Les Elections Legislatives du 24 Avril 1960 (Vientiane: Editions Vieng-Kham, 1960), pp. 7-9.

60. For Pham Van Dong's letters to the Geneva Co-chairmen (March 3) and to the ICC (March 8), and Gromyko's letter to the British Government (April 18), see Hsinhua News, March 5 and 11 and April 21, 1960. 
61. "Imperialism-Source of War in Modern Times-and the Path of the People's Struggle for Peace," Hung-ch'i [Red Flag] (Peking: April 1, 1960), pp. 1-12.

62. For CIA's involvement, see Dommen, Conflict in Laos, op. cit., p. 133.

63. Peking Review (May 17, 1960), p. 25.

64. See Wilfred G. Burchett, The Furtive War: The United States in Vietnam and Laos (New York: International Publishers, 1963), pp. 175-177.

65. Quoted in Frank M. Le Bar and Adrienne Suddard (eds.), Laos: Its People, Its Society, Its Culture (New Haven: Human Relations Area Files, Inc., 1960), p. 142.

66. For the NLH's June 6, 1960, statement, see Yin-tu-chih-na-wen-t'i-wen-chien-hui-pien, Volume III [Collected Documents Concerning Problems in Indo-China] (Peking: 1961), pp. $58-59$. 


\section{Chapter IV \\ The Chinese Policy of Negotiations at The Second Geneva Conference}

Section One: A Prelude to the Geneva Conference on Laos

A sudden change in the balance of politics in Vientiane often profoundly affected the direction of China's approach toward Laos. Just such a development took place in Vientiane on August 9, 1960, when Captain Kong Le, an American-trained commander of the second parachute battalion, staged a successful coup d'état overthrowing the proU.S. government of Premier Tiao Somsanith and Gen. Phoumi Nosavan. ${ }^{1}$ As Kong Le's "Revolutionary Committee" announced his primary objectives to eliminate America's "increasingly intensified intervention" and to resume a neutral foreign policy, the Chinese seized this fortuitous opportunity in an attempt to realize their hitherto unsuccessful policy for restoration of the status quo prior to July, 1958, in Laos. ${ }^{2}$ They welcomed the anti-American position of the coup leaders and encouraged the Pathet Lao to organize a broad united front against the United States and the Laotian right-wing groups.

In People's Daily of August 19, 1960, the Chinese defined the coup as the Laotian people's "forceful reply" to the U.S. "aggressors" and the Phoumi Nosavan forces. As soon as Prince Souvanna Phouma was reinstated as premier, Chou En-lai sent him a congratulatory message hoping that China and Laos would establish and develop friendly and peaceful relations. ${ }^{3}$ This initiative was obviously intended to revive the spirit of the Peking-Vientiane understanding, which had effectively been undermined by Phoui Sananikone and Phoumi Nosavan. The Neo Lao Haksat Central Committee proposed negotiations with Premier Souvanna Phouma to reestablish a coalition government composed of "representatives of various nationalities and of patriotic and progressive political parties." This formulation excluded from the proposed coalition the "reactionaries," who were by definition neither "patriotic" nor "progressive." It was thus designed to discourage Souvanna Phouma's efforts to include Phoumi Nosavan in a new national government. ${ }^{4}$

After rejecting Souvanna Phouma's overtures for national unity, 
Phoumi Nosavan organized a "New Revolutionary Committee" at Savannakhet under the titular leadership of Prince Boun Oum and pledged to fight against Kong Le. Even though the United States recognized Souvanna Phouma's government, it attached great importance to the Savannakhet movement. Acknowledging this beginning of a "revolution" at Savannakhet, the State Department warned that the United States would be immediately concerned by "the efforts of any other outside power, or the agents thereof, to take advantage of the disturbed conditions prevailing and to intervene directly or indirectly." With this threat against the Pathet Lao leaders and their Communist supporters, the United States gave military assistance to Phoumi Nosavan's troops through channels in Thailand. And the Thai Prime Minister, Marshall Sarit Thanarat, instituted a blockade of the Mekong River against Vientiane and assisted Phoumi Nosavan in various ways. But the contradictions in U.S. policy increased Premier Souvanna Phouma's suspicions about Washington and in effect drove him toward the Communist embrace.

In early October, Souphanouvong further proposed that Souvanna Phouma should form a coalition government with NLH representatives and accept diplomatic relations with socialist countries. As soon as negotiations started between the RLG and the NLH in Vientiane, the United States sent Assistant Secretary of State Parsons to Laos to break up the negotiations and to bring about a reconciliation between Souvanna Phouma and Phoumi Nosavan. When Parsons' efforts proved futile, the United States openly opposed Souvanna Phouma, who was forced to receive support from the Communist side in the face of Phoumi Nosavan's growing military activities. In November, the RLG and the $\mathrm{NLH}$ agreed, among other things, to accept aid from Peking and Hanoi and to send an economic and cultural delegation to both capitals. $^{6}$ After their meetings in Sam Neua in November, 1960, Princes Souvanna Phouma and Souphanouvong pledged to pursue a neutral foreign policy without leaning toward either world camp and to form a coalition government represented by all minorities and patriotic parties, including the NLH. These agreements in effect restored the 1957 Vientiane formula, but without the consent of the Laotian right-wing organizations. Having sought rapport with Vientiane ever since the 1954 Geneva Conference, the Chinese were no doubt pleased with these 
rapid developmens in Laos and issued a Government statement on November 20, expressing their willingness to take "corresponding measures" for Sino-Laotian cooperation. ${ }^{7}$

Shortly thereafter, the Chinese expectations for establishing friendly, diplomatic relations with Laos were dashed. In the middle of December, Gen. Phoumi Nosavan occupied Vientiane and set up a pro-American government under Premier Boun Oum. Thus Laos was again plunged into civil war, intensified and complicated this time by the military aid America and Russia were offering to each of the combatants. The Chinese evidently regarded such power politics on their sensitive periphery as a potentially serious challenge to their own national interest; suddenly, they began taking a number of initiatives. ${ }^{8}$ As the United States further bolstered Phoumi Nosavan's northern march toward the Sino-Laotian border with military advisers and vital armaments-including M-24 tanks and 105-mm howitzers, the Chinese Government promptly and repeatedly cautioned the United States against its "biggest armed intervention" in Indo-China since 1954, and bitterly condemned its "scheme" to turn Laos into a military base for attacking China and Vietnam. To safeguard its own security, Foreign Minister Chen Yi declared, the CPR might find it necessary to take "proper measures" against the United States.

The anticipated diplomatic contact between Peking and Vientiane was also disturbed by the disintegration of Souvanna Phouma's government; his original plan to visit China was postponed indefinitely as he was forced to take refuge in Cambodia. Moreover, China's expectation of leading the Pathet Lao's national liberation movement was subtly undermined by effective policy coordination between Moscow and Hanoi. These two partners arranged, among other things, Russia's airlift of war materiel to the Pathet Lao-Kong Le allied forces, thus strengthening Moscow's political leverage in the management of Laotian affairs. Indeed, Khrushchev assumed this difficult air operation in a remote country mainly to check China's growing influence there and to quiet criticisms of his "sell-out" to the United States. ${ }^{10}$

The Chinese, we can imagine, conceived two possible responses to the crisis: either to compete with Moscow and Hanoi in rendering direct military assistance for the Pathet Lao's continuing armed campaign (a measure likely to induce further American involvement in 
Southeast Asia) or to help arrange a negotiated settlement of the escalating conflict. Notwithstanding their prolific warnings and vituperations against the U.S., the Chinese manifested self-restraint in avoiding a risky adventure in Laos. They carefully refrained from making specific commitments that might force them into a direct military confrontation with the United States and other SEATO powers. They appeared particulary uneasy about the emergency sessions of the SEATO Council on Laos and American naval maneuvers, including the dispatch of the Seventh Fleet to the South China Sea. As the possibility of wider military clashes loomed larger, the Chinese showed themselves receptive to the notion of an international conference on Laos. Only three months earlier they had dismissed a similar idea suggested by Prince Souphanouvong and Cambodia's Prince Norodom Sihanouk. On December 19, 1960, however, they endorsed Hanoi's proposals for unconditional reconvocation of the 1954 Geneva Conference and for reactivation of the International Commission in Laos, which had been adjourned sine die since July, 1958. ${ }^{11}$

But the Chinese tried to hamstring the revived Commission by insisting that it work through Souvanna Phouma's government on practical measures relating to the Commission's activities. In a letter to the Geneva Co-chairmen, Chen Yi said that should the Commission with its Indian Chairman have any contact with the American-British sponsored government of Boun Oum, there would be "extremely serious" consequences. ${ }^{12}$ Aware of Indian Prime Minister Nehru's ambivalent attitude toward the two rival governments of Laos, Chen Yi undoubtedly intended to put off any peace-making attempt by the Commission until the Pathet Lao forces gained a military upper hand. ${ }^{13}$ Only this, the Chinese figured, could guarantee a favorable outcome in negotiations with "reactionaries" and "imperialists" who would never give up their "butcher's knife" voluntarily. ${ }^{14}$

At the same time, the Chinese evidently felt obliged to demonstrate that "united action" among Communist states was both an effective deterrent against America's encroachment in Southeast Asia and a strong diplomatic force for negotiations. Nowhere was this calculation more clearly reflected than in the People's Daily editorials of December 25, 1960, and January 1, 1961. Noting that China, Russia, and North Vietnam were signatories and guarantors of the 1954 Geneva agree- 
ments as well as "true and loyal friends" of national liberation movements, the Chinese asserted that the three countries should jointly assume the "inescapable responsibility to make common efforts for safeguarding the Geneva agreements and restoring peace in Laos." In January, 1961, the three Communist states accepted Sihanouk's proposal that the conference on Laos should be attended by fourteen countriesseven "signatories" of the 1954 Geneva agreements, three member-states of the International Commission, the United States, and three remaining neighbors of Laos. On his part, Sihanouk reasoned that "in order to remain on good terms with my Communist friends, we prefer not to have a common frontier with them." 15

Fearing that all Southeast Asia might succumb if the Communists gained a foothold in Laos, President Eisenhower flatly rejected all proposals for an international parley and promised to underwrite Phoumi Nosavan's illusory designs of destroying the Pathet Lao-Kong Le allied forces. In an attempt to deter Communist adventurism in Laos, he ordered the U.S. forces in the Pacific to combat readiness and issued a warning against "any intervention in Laos by the Chinese Communists or Viet Minh armed forces or others in support of the Communist Pathet Lao."16 In his talks with President-elect John F. Kennedy, Eisenhower said that the United States should be prepared to take unilateral military action in Laos if necessary, but not to accept the formula of a Laotian coalition including Communists. ${ }^{17}$

When Kennedy became president, he could do little, despite his comparatively balanced view of China and Laos, to change Eisenhower's hard-line Asian policy-at least for the first few months. In his first State of the Union message delivered in January, 1961, Kennedy observed that "the relentless pressures of the Chinese Communists menaced the security of the entire Asia down to the jungles of Laos."18 Despite the change in leadership, the United States continued to oppose any conference which might be used against its position in Asia; instead it supported the British proposal for reactivating the International Commission, which alone might be expected to stabilize the situation in Laos.

Now that both Britain and America were trying to revive the Commission, the Chinese stiffened their position; they argued that the Commission should not resume its functions until its terms of reference 
were redefined by a new international conference. This position was subsequently adopted by Princes Sihanouk, Souphanouvong, and Souvanna Phouma. It was revealed in China's secret military documents that the Chinese, aware that Phoumi Nosavan's forces held a "fairly favorable position" in military affairs, were seeking a "certain period of time" during which the Pathet Lao and neutral troops could increase their strength in preparation for a "long-drawn out, complicated, and devious" struggle. ${ }^{19}$ But the Russians, more flexible, even suggested in February that the Commission might meet first in New Delhi and report to the Geneva Co-chairmen.

As their primary diplomatic objective was to open a conference on Laos, the Chinese vigorously opposed any other alternatives. On February 19, King Savang Vatthana, after close consultations with American Ambassador Winthrop G. Brown, proposed that a Commission of Neutral Nations, composed of Burma, Cambodia, and Malaya, would protect Laos against the danger of external interference. He also asked the United Nations Secretary-General to inform all member-states of the U.N. of his adherence to peace and neutrality. ${ }^{20}$ To discredit the King's statement (which was in fact drafted by the U.S. State Department), the Chinese opened a fierce propaganda campaign against what they labelled "nothing but an American intrigue." They argued: the United States invented this proposal to bury an international parley, to use the prestige of Burma and Cambodia for recognition of Boun Oum's government, and to pursue its interventionist policy through Malaya, which was not a "neutral" country but a "tool of imperialism."21 China's strong objection was instrumental in pressuring both Burma and Cambodia to dissociate themselves from the proposed Commission which could otherwise have been a regional substitute for the International Commission in Laos.

As the King's proposal thus collapsed, the United States persuaded Phoumi Nosavan to reach conciliation with Souvanna Phouma. In early March, Phoumi Nosavan met with Souvanna Phouma in Phnom Penh and invited him to return to Vientiane. Souvanna Phouma first proposed negotiations among the three Laotian groups, but his efforts failed in the face of the Pathet Lao's opposition. By late March, however, President Kennedy became well aware of the failure of his initiatives and of the vulnerability of Phoumi Nosavan's forces against the 
reviving strength of the Pathet Lao. Indeed, the latter reestablished its revolutionary bases in the northern provinces and claimed to occupy more than half of Laos. In the process of reassessing U.S. policy, Kennedy contemplated, then rejected, the unilateral use of limited American forces on Phoumi Nosavan's behalf. He decided not to escalate the local conflict into a major ground war in Asia but to seek its peaceful settlement.

On March 23, while Britain proposed to Russia that after the Commission's verification of de facto cease-fire throughout Laos the Geneva Co-chairmen should convene an enlarged Geneva Conference, Kennedy held a press conference to endorse the British proposal and to announce a reorientation of U.S. policy in favor of "peace, not war-a truly neutral government, not a cold war pawn-a settlement concluded at the conference table, not on the battleground."22 To make his stand more effective and check the worsening military situation in Laos, he demanded that "externally supported Communists" immediately cease their aggression. If the attacks did not stop, he warned, all SEATO members would undertake special treaty responsibilities toward the beleaguered Laos. A series of SEATO military maneuvers underlined Kennedy's determination to resist a Communist takeover of Laos-a position directly communicated to Peking through ambassadorial talks in Warsaw. ${ }^{23}$

Against the complex background of U.S. diplomatic flexibility coupled with military warnings, China accepted the substance of the British proposal, at the same time calling America's "bluff" on military intervention in Laos. Responding to an American correspondent's question at his Djakarta press conference on April 2, Chen Yi made it clear that if SEATO members really sent their troops to take part in the civil war in Laos and if the Chinese were called upon by Souvanna Phouma's legal government, they would not remain idle. ${ }^{24}$ The exchange of these threats and maneuvers between China and America apparently checked each other and contributed to the process of their moderation. In a closed-door meeting with the U.S. Ambassador at Warsaw, Chinese Ambassador Wang Ping-nan informed him that China was serious about wishing to negotiate rather than fight and to work out an acceptable agreement for neutralization of Laos. ${ }^{25}$

In the meantime Britain and Russia, as Co-chairmen of the Geneva 
Conference, followed a more moderate path of mutual consultations. On April 24, the two Co-chairmen reached a complete agreement on three measures leading to the enlarged "International Conference for the Peaceful Settlement of the Laotian Question." ${ }^{26}$ First, they called on all military authorities, parties, and organizations in Laos to cease fire. Second, they requested the Indian Government to convene the International Commission in New Delhi so that it could carry out the work of controlling the cease-fire in Laos and present an appropriate report to the Co-chairmen. Finally, they invited fourteen states, as suggested by Sihanouk, to participate in the Conference, which was scheduled to open at Geneva on May 12, 1961.

These preliminary arrangements showed that the major world powers concerned with Laos were willing to make procedural concessions for the sake of negotiations. While America and Britain accepted the Conference, the Communist side agreed to a cease-fire verified by the Commission. China also retreated from its previous insistence that the Conference should precede the Commission's resumption. Indeed, from December, 1960, to April, 1961, there gradually emerged a tacit understanding among the major powers with regard to the general formula for a negotiated settlement: first, an international neutralization of Laos to be supervised by the International Commission; and, second, a coalition government to be composed of three rival Laotian groups under Souvanna Phouma's premiership. This international consensus, combined with the Pathet Lao's improved military position, promised a number of practical advantages for the Chinese.

For a truly neutral Laos-U.S. military personnel and Russian airlift eliminated-would protect Chinese security against the U.S. and increase their influence over the Pathet Lao vis-à-vis Russia. The Chinese could also look forward to closer relations with a unified Laos, for, in a joint statement signed with Chou En-lai in April, 1961, Souvanna Phouma agreed to establish diplomatic relations and exchange economic and cultural missions. ${ }^{27}$ Recognizing the convergence of their own interest with Souvanna Phouma's anti-imperialist nationalism, they hoped that he would emulate Sihanouk's brand of neutral policy rather than Nehru's and would strengthen the united front with the Pathet Lao against the Phoumi Nosavan-Boun Oum group. But they were aware that the U.S. might misconstrue their acceptance of negotiations 
as a sign of weakness or use the negotiations as a breathing-spell for further military actions. When they accepted the Co-chairmen's invitation to the Geneva Conference on April 26, the Chinese particularly warned against U.S. "intentions" to resume intervention in Laos following the cease-fire. ${ }^{28} \mathrm{~A}$ similar warning was reiterated by Chou En-lai on May 8, when he exchanged views with the representatives of Souvanna Phouma, Souphanouvong, and Ho Chi Minh. ${ }^{29}$

Section Two: Chinese Positions and Tactics at Geneva

The opening of the Conference was delayed four days by disputes over verification of the cease-fire and representation of Laos at Geneva. The United States delegation, recalling how the Viet Minh had strengthened its negotiating position by continuing to fight even while the 1954 Conference was in session, refused to start negotiations this time unless the Pathet Lao forces stopped all military activities. The issue was at least temporarily resolved by the International Commission's report verifying a de facto truce throughout Laos. But the representation question, involving a decision on the relative status of two rival Laotian governments (those of Souvanna Phouma and Boun Oum) and of the Pathet Lao, proved more complicated. Whereas Chou En-lai, in 1954, had compromised the Pathet Lao's representation to achieve an Indochinese settlement, the Communists believed in 1961 that the Pathet Lao's increase in power since 1954 should be fully reflected in any new Laotian arrangement. After British Foreign Secretary Lord Home and French Foreign Minister Couve de Murville had softened Secretary Dean Rusk's opposition to the Pathet Lao's participation, the Geneva Co-chairmen agreed that any Laotian group could be represented at Geneva if it was sponsored by a participating country. This enabled China to sponsor the Pathet Lao delegation, and Russia, Souvanna Phouma's delegation at the Conference. Nevertheless Boun Oum decided to boycott the Geneva Conference but to participate in the meetings of the three Laotian groups. ${ }^{30}$ While the tripartite talks were intended to resolve such "internal" questions as coalition government, cease-fire agreements, general elections, democratic freedoms, and foreign relations, the Geneva Conference was confined to the "international" aspect of defining and guaranteeing Laos' neutrality.

At the Conference the Chinese sought more than a peaceful settle- 
ment of the Laotian question. Intent on demonstrating their growing power and status, they came to Geneva with the largest delegation, engaged in expensive social activities, and carried on extensive public relations efforts and a militant anti-American campaign. ${ }^{31}$ On May 16, in his first speech, Chen Yi charged that the American policy of intervention and aggression in violation of the 1954 Geneva agreements had caused prolonged instability in Laos and that SEATO, the principal tool of such an American policy, had brought about the tense situation in Southeast Asia. ${ }^{32} \mathrm{He}$ demanded that SEATO be abolished and that U.S. and allied military personnel, including the KMT irregular troops remaining along the Laotian-Burmese border, be withdrawn from Laos. In order to replace SEATO and guarantee Laotian neutrality, Chen Yi advocated the establishment of a "peace zone" in Southeast Asia first and then in other parts of Asia. By attacking U.S. military commitments in the entire region, he sought to broaden the scope of discussion at Geneva. On May 24, he presented five principles to be applied in any solution of the Laotian problem: (1) adherence to the 1954 Geneva agreements, (2) respect for the independence and sovereignty of Laos, (3) strict insurance of Laotian neutrality, (4) sharp distinction between Laos' internal problems to be resolved by the Laotians themselves and external problems to be discussed at Geneva, and (5) acceptance of the common agreements by all Geneva participants. ${ }^{33}$

Concept of Neutrality: The fundamental task facing the Geneva Conference was to define the nature of international neutralization in the cold-war context and to stipulate the responsibilities of a neutralized state, the guaranteeing countries and the international control machinery. The participants at first discussed intensely the various interpretations and implications of the concept of neutrality, crucial to the negotiations for a Laotian settlement.

In his opening address Dean Rusk first advanced a definition of neutrality which he argued should "go beyond the classical concept of nonalignment and include positive assurance of the integrity of the elements of national life." ${ }^{\text {"34 }}$ A truly neutral Laos, he said, should have the right to choose its own way of life in accordance with its own traditions and aspirations but must be safeguarded by the effective control machinery against subversive activities organized and assisted beyond its borders. After characterizing Rusk's thesis as an attempt to place 
Laos under "international condominium" through the powerful control instrument, Chen Yi presented both a refutation and an alternative. The real motive of Rusk's definition, he asserted, was to deny the Laotian people's right to assume a neutral status of their own choosing; for the ideas of "positive assurance" and "protection of neutrality" were an extension of the "logic" of SEATO, which outwardly professed to protect the neutrality of Laos but actually intended to interfere in its internal affairs.

The Chinese did not bind their hands by a legalistic approach to neutrality which would require only that belligerent countries not interfere in Laos and that Laos be impartial toward the actions of belligerent countries. Their arguments at Geneva revealed a concept of neutrality for Laos based on three major elements. First, Laos must refrain from accepting any military alliance or protection and from allowing any foreign military personnel or base on its territory. Second, she was to have absolute political independence. Finally, she would pursue a neutral foreign policy, establishing "friendly relations" with all countries. The Chinese were in effect suggesting that to be genuinely neutral and impartial, Laos must be friendly toward the CPR; indeed, they gave this requirement high priority among what People's Daily (May 20, 1961) called the "practical conditions" for Laos' neutrality. Even more significant was the second element-that no foreign country (this meant the Geneva Co-chairmen too) or outside machinery (the International Commission!) should be permitted to intervene in the "domestic" affairs of an independent sovereign country, especially in the formation of a coalition government and the integration of armed forces and administrative units. The Chinese emphasized the notions of "independence" and "sovereignty" of Laos not so much because they considered these notions inherent in neutralization as because they could use them to maximize the Pathet Lao's political freedom and to reduce the Commission's function as much as possible.

International Commission: The Commission, said the Chinese, was meant to supervise the cease-fire and withdrawal of foreign forces from Laos and to investigate the introduction of new foreign contingents with the RLG's prior consent. They tried to minimize the Commission's authority mainly because India's attitude since the 1954-58 period had seemed to grow increasingly unfriendly. More realistically, they 
were profoundly skeptical about the Commission's role in a milieu of power politics. Chen Yi once said: "Isn't there also an international control commission in the southern part of Vietnam, but has it stopped the increasingly serious armed U.S. intervention in South Vietnam?"35 But the Chinese did not take an extreme initiative to change the Commission's membership or chairmanship as their political realism foresaw the unpopularity of such a move.

It was thus their "essential struggle" at Geneva to oppose the Western argument that the Commission exercised broad, free, and automatic functions to guarantee strict implementation of the agreed provisions against the likelihood of Communist subversion. At the outset Dean Rusk proposed a veto-free control machinery empowered to protect Laos against subversion, to have free access to all parts of the country, and to investigate any complaints presented by "responsible sources" ranging from the Commission's members and the Geneva Conference participants to Laotian civil and military officials. On the basis of the 1954 provisions, which had provided a wide range of responsibilities for the Commission, France's Jean Chauvel further suggested that the Commission should have the freedom to inspect "all aerodromes, installations or establishments and all units, organizations and activities which are or might be of a military nature." In ten articles supplementing the French proposal Ambassador W. Averell Harriman specified that all Laotian groups must regularly report to the Commission regarding the location, organization, strength, and nationality of their forces and the location, types, and quantity of their armaments. The Commission, he added, should establish procedures for disposing all arms and equipment beyond the national need. ${ }^{36}$ In short, the Western powers intended to equip the Commission with comprehensive and unrestricted supervisory and investigative power in Laos.

The Chinese categorically dismissed these Franco-American proposals as an attempt to set up an international trusteeship over Laos. They also argued against an automatic extension of the Commission's 1954 terms on the ground that the present civil war in Laos was different from the international war in Indo-China in 1954. ${ }^{37}$ Arguing that the status of a country's armed forces was a matter of domestic jurisdiction, the Chinese opposed most vigorously the Western proposal that the Commission supervise all questions of Laos' internal military arrange- 
ments, including the integration of three armed forces. This proposal, the Chinese asserted, was intended to interfere in the strictly internal affairs of an independent country and to wipe out the Pathet Lao and neutral forces. In this regard they must have remembered that the Pathet Lao's acceptance of military integration in November, 1957, had led to tragic failure by May, 1959. The Western position, however, was substantially weakened by an agreement reached among Princes Souvanna Phouma, Souphanouvong, and Boun Oum, who decided in June, 1961, to realize the unification of separate armed forces into a single National Army, according to a program agreed upon by three sides.

The Chinese objected likewise to Harriman's earlier proposal, whose purpose, they charged, was to fix the type and quantity of Laotian armed forces and to get all defense secrets of Laos. Neutrality, Chen Yi maintained, was not synonymous with disarmament; in order to preserve its sovereign independence, even a neutral nation must control its own defense requirements. The Chinese also opposed the Western and Indian proposals that the Commission control the introduction of military supplies into Laos. Although they defeated most of the Western proposals on military affairs, the Chinese accepted a compromise on the last one: the Commission should "assist" the Royal Laotian Government in cases where introduction of military supplies exceeded the requirements of national defense, but this assistance should be rendered only at the RLG's request.

To make the Commission's operations flexible and efficient, both America and France proposed that decisions be taken by majority vote. When Soviet Foreign Minister Gromyko proposed the principle of unanimous agreement except in decisions of a purely procedural nature, Chinese Deputy Foreign Minister Chang Han-fu explained that the "principle of unanimity through consultations" simply reflected the cooperation among three political persuasions-socialist, neutral, and pro-Western-without which no international issue could properly be resolved in contemporary world politics. ${ }^{38}$ Though the majority rule appeared effective and democratic in domestic politics, Chang added, it should not always apply to multi-national relations as it amounted to imposing one state's will upon others. In their external affairs the Chinese were indeed unwilling to accept majority rule, even in international Communist meetings, perhaps because the pattern of China's 
traditional political processes, both domestic and external, was basically consensus-oriented. But a more practical calculation behind the Chinese argument for unanimity was to equip the Polish member of the Commission with a veto power and thus prevent the possibility of IndianCanadian majority control. As a compromise, however, the Western powers accepted the unanimous rule in substantive issues while the Communist side agreed to the majority rule in initiating and carrying out investigations (as well as in purely procedural cases).

The compromise was made possible by the persuasive diplomacy of Moscow, which, lacking China's mistrust of the Indian Chairmanship, took a more pragmatic attitude on the Commission and recognized the importance of its effective peacekeeping activities in Laos. Compared with the 1954 provisions the Commission's overall authority was considerably weakened; its terms of reference were more limited and its voting procedures were more restrained. For all practical purposes the Commission could act only to the extent that the mutuality of interests and the reality of power relations, both within and without Laos, would permit. $^{39}$

Co-chairmen: In an attempt to extend the Geneva Co-chairmen's authority over the Commission, Gromyko proposed that the Commission conduct its activities on the instructions of and under the general supervision of the Co-chairmen. The United States, encouraging the moderating influence of Moscow in Laos vis-à-vis Peking and Hanoi, gave the proposal prompt support. But the proposal failed to win the consent of Peking, which was frankly opposed to additional Russian influence in Laos, and so was soon given up. As a kind of review authority, however, the Co-chairmen assumed responsibilities for exercising general guidance over the Commission and for making recommendations to and receiving reports from it. And as a channel of diplomatic accommodation and communication they would supervise observance of the agreements, keep the Geneva Conference participants constantly informed, and consult with them whenever appropriate.

Military Provisions: It was not difficult for the guaranteeing countries to agree on the military requirements of Laos' neutrality: all foreign military personnel would be withdrawn, no new forces would be introduced, no alliance would be formed, and no military pressure would be used against Laos. In accordance with the 1954 agreements 
an exception was made that France would for a limited period of time leave a specified number of military instructors to train the Royal Army and would maintain two military installations, pending their transfer to Laos. This was first opposed but later accepted by the Chinese, who expected France to respect the principle of Laos' military neutralization.

At Geneva the Chinese delegation was most vociferous about the "several thousand" Kuomintang irregulars, whom, it claimed, the United States had instigated to join Phoumi Nosavan's campaign near the Sino-Laotian border. Denouncing this "root cause of evil" in Mekong River countries, Chang Han-fu accused the United States of avoiding the problem of disarmament and evacuation of these forces from Laos. Curiously, the Russians were largely indifferent to this "Chinese" issue, perhaps because they were reluctant to justify China's deeper involvement in Laos and thus complicate the process of negotiations. ${ }^{40}$ Even though Harriman denied American responsibility for the Kuomintang irregulars, he suggested that the Commission insure their evacuation if necessary. While the combination of Harriman's reasonable response and Moscow's indifference minimized the impact of the Kuomintang question on negotiations, the Chinese could not but rely upon a general provision requiring the withdrawal of all foreign military personnel from Laos.

South Vietnam embarrassed both Hanoi and Peking by proposing to ban the use of Laotian territory and resources for the purpose of aggression against other countries. Obviously intended to deny Hanoi use of the Pathet Lao-controlled area as a corridor of infiltration into South Vietnam, the proposal implied a denunciation of Hanoi's efforts at national unification. ${ }^{41}$ The Chinese argued that the proposal could even undermine Laos' independence and sovereignty by empowering the Commission to investigate cases of violation and by placing all of Laos' borderlands under U.S. control through the Commission. Nevertheless, as they could not continue to refuse this legitimate proposal supported by Souvanna Phouma, the Communist delegations accepted it with a face-saving quid pro quo: the guaranteeing states should not use Laos' territory for interference in other countries, nor should they use other countries' territory for interference in Laos. ${ }^{42}$

SEATO: The relationship between SEATO and Laos was a source of persistent controversy among the major powers at Geneva. Chen Yi 
endorsed Gromyko's proposal for abrogation of SEATO's protective role over Laos, but took a more radical step in demanding the total abolition of SEATO itself. He said that SEATO, by placing Laos, Cambodia, and South Vietnam under its protective umbrella, had interfered in their internal affairs and had disturbed the conditions of peace in Southeast Asia. But the Western powers claimed that Laos' neutrality was compatible with SEATO, as SEATO aid could be extended only at Laos' request. It was Harriman's opinion that the removal of SEATO's protection from Laos required an amendment of the Treaty, but four of its member-states were absent from the Geneva Conference.

When the three Laotian Princes agreed in June, 1961, not to recognize the "protection of any military alliance or coalition," the Chinese promptly seized upon it and intensified their anti-SEATO campaign. In accordance with the "national aspirations" of Laos, Chang Han-fu insisted, SEATO's protective terms over that country should be completely abrogated. In spite of this unsettled question, the Conference was able in December, 1961, to achieve provisional agreements on the international aspect of Laos' neutrality. ${ }^{43}$

Meanwhile, negotiations among the three Laotian groups reached an impasse, thus keeping the Geneva Conference from further progress. On December 27, after a brief meeting with Souvanna Phouma and Souphanouvong at Vientiane, Boun Oum suddenly called their earlier agreements on coalition government invalid and demanded the portfolios of defense and interior for his right-wing group. This represented Boun Oum's and Phoumi Nosavan's dissatisfaction with the progress made at Geneva and their lingering illusions of total military victory against the Pathet Lao-King Le forces. When, in early 1962, Boun Oum and Phoumi Nosavan still resisted pleas for moderation from Home and Harriman, the Chinese ridiculed U.S. inability to control the Laotian right wing and condemned U.S. tactics of "political blackmail" at Geneva and "military adventurism" in Laos.

In a direct polemical confrontation on January 23, 1962, U.S. delegate William H. Sullivan, challenged by Chang Han-fu's accusation of America's "double-faced" policy, replied that although China was trying to provoke a war between America and Russia, neither country would fight over Laos to China's advantage. In the middle of heated 
debates, Soviet Deputy Foreign Minister Georgi M. Pushkin objected to Sullivan's intention to place Russia against China and said both Communist countries had the identical objective of a peaceful settlement in Laos. ${ }^{44}$ But the Chinese directed more serious attention to the aggravating military situation within Laos. They denounced Phoumi Nosavan's large-scale offensive in Nam Tha (Houa Khong) province and U.S. jet-fighters' alleged bombing in northern Laos. They also noted that the United States had increased its military advisers in Laos from 1,000 in July, 1961, to 1,300 in March, 1962, and had used more than 3,000 Kuomintang troops to support Phoumi Nosavan. ${ }^{45}$

The Geneva Conference reached its most critical stage in the middle of May, 1962. With the Pathet Lao's decisive victory at Nam Thaalmost equal to Dien Bien Phu in its psychological impact on the Western powers-President Kennedy on May 17 ordered more than 5,000 marines and military personnel to proceed to the Thai-Lao border. Following a SEATO Council meeting which justified the U.S. move as "entirely precautionary and defensive," Britain, Australia, and New Zealand dispatched their air forces to Thailand. ${ }^{46}$ The Chinese immediately responded to this threat by warning that they would not remain indifferent toward an American policy of "direct military intervention" in Laos threatening "Chinese security." 47 Unlike Moscow's rather mild reaction to these "complications" in the region bordering Laos, both Peking and Hanoi took an extremely tough attitude at the Geneva Conference. While Peking demanded immediate and complete withdrawal of U.S. and allied forces from the Thai-Lao border, Hanoi threatened that it would not sign any agreement on Laos unless those foreign forces were completely withdrawn from Thailand. Even when the Pathet Lao obtained the best opportunity to conquer Laos, there was little evidence to suggest that the Chinese encouraged the Pathet Lao leaders to take an extreme military step. Probably they advised the Pathet Lao leaders to use their military advantage not for conquest but as a strong negotiating point.

Indeed, the high tension brought about vigorous diplomatic activities by the Geneva Co-chairmen and expedited the negotiations among the three Laotian groups. On June 12, the three Princes concluded the Plain of Jars agreements, setting up the organization and operational principles of a provisional coalition government. Souvanna Phouma's 
neutral group took seven portfolios, including defense, interior, and foreign affairs, while the Pathet Lao, the right-wing group, and the Vientiane "neutralist" group each received four seats. ${ }^{48}$ Premier Souvanna Phouma and Vice-Premiers Phoumi Nosavan and Souphanouvong were respectively to hold the posts of defense, finance, and economic planning. Finally, the coalition would apply the unanimous rule in decisions on all important questions, while decisions in the ministries of defense, interior, and foreign affairs were to be made by the highest representatives of the three political groups. As soon as a new Laotian Government was sworn in, the Chinese Government extended its recognition and proposed an exchange of Ambassadors. ${ }^{49}$

The ultimate solution of the remaining issue of SEATO lay with the new Laotian Government, whose declaration on neutrality specifically repudiated the "protection of any alliance or military coalition, including SEATO." After long consultations among themselves, the SEATO powers expressed their acceptance of the Laotian declaration. Contrary to Harriman's earlier interpretation, the SEATO powers considered an amendment to the Treaty unnecessary. As Professor Modelski observed, this loss of nerve by the United States amounted to a public "censure" of SEATO and damaged its prestige in Southeast Asia. $^{50}$

On July 23, 1962, the fourteen-month Conference ended with the fourteen participating countries signing a Declaration on the Neutrality of Laos and an accompanying explanatory protocol. Compared with the 1954 Geneva agreements, the RLG in 1962 assumed more precise and varied responsibilities to build a "peaceful, neutral, independent, democratic, unified and prosperous Laos." ${ }^{" 1}$ In a statement incorporated into the Geneva agreements and promulgated constitutionally, the Royal Laotian Government pledged to apply the five principles of peaceful coexistence in foreign relations and to develop friendly relations and establish diplomatic relations with all countries, the neighboring countries first and foremost. It also declared:

It [the RLG] will not enter into any military alliance or into any agreement, whether military or otherwise, which is inconsistent with the neutrality of the Kingdom of Laos; it will not allow the establishment of any foreign military base on Laotian territory, nor allow any country to use Laotian territory for military purposes or for the purposes of interference in the internal affairs of other countries, nor recognize the protection of any alliance or military coalition, including SEATO. 
To respect and assist these Laotion intentions, the guaranteeing countries promised to observe in every way the sovereignty, neutrality, unity, and territorial integrity of Laos and undertook a multitude of specific obligations. Whenever appropriate, the guarantors might jointly consult with the RLG and among themselves to consider measures for insurance of the agreements. This joint consultation signified the inadequate provision for enforcement action; for it could nullify the legality of any partial consultations or could foreclose any other effective enforcement measures, such as a Locarno model, where the guarantors had the right to act without unanimous agreement among themselves. The Geneva Conference rejected the French proposal for periodic ambassadorial meetings among the guarantors to consider the International Commission's work.

\section{Section Three: Evaluation of the Second Geneva Formula}

In a sense the Geneva Conference marked an attempt to resolve one aspect of the Sino-American conflict in Southeast Asia. Other powersespecially, Britain, Russia, France, and India-seemed to have made efforts to bridge the positions of those two extreme antagonists. Despite these moderating influences the Chinese scored a considerable diplomatic victory at America's expense. They forced the United States to accept the withdrawal of its military advisers and SEATO's protective umbrella from Laos, to agree to the reduction of the Commission's power, and to acknowledge the coalition government with Pathet Lao representation. In the general tone of their statements and arguments at Geneva, the Chinese radiated confidence in their ideological commitments. This does not mean that the Chinese were so obsessed with revolutionary convictions and abstract dogmas that they would not negotiate realistically. On the contrary they were conciliatory and business-like in small, informal, and less publicized meetings-such as the restricted sessions of the Geneva Conference, the Drafting Committee discussions, and some twenty informal consultations at which crucial negotiations took place among six core delegations (Britain, Russia, America, China, France, and India) or among four (without France and India)..$^{\mathbf{2}}$

In the process of compromise the Chinese made a number of important procedural concessions and accepted the "corridor" provision, the 
Commission's limited control over the introduction of military supplies, and the majority rule in investigative decisions of the Commission. Their ambition of wrecking SEATO was also abandoned. This negotiating pattern suggests that in spite of their ideological commitments and self-centered world outlook, the Chinese were capable of conducting pragmatic negotiations as long as their status and interest were duly recognized. It also shows that they were willing to accept a negotiated settlement of a conflict if they were convinced either by the threat of force or by the logic of a situation that a negotiation was more advantageous to their own national interest than any other available option and if they were reasonably assured of its likely outcome.

At Geneva the Chinese maintained a remarkable degree of outward unity and coordination with Moscow and Hanoi in order to defend common interests and denounce Western proposals. But they could not always conceal their subtle differences with Moscow in diplomatic tactics and strategic calculations toward Laos and America. Moscow showed a lukewarm interest in the questions of China's security and Kuomintang troops, appeared more willing to expedite a peaceful settlement in Laos, and preserved a basic communication with the United States. While Gromyko attributed the successful negotiations to the Kennedy-Khrushchev joint statement of June 4, 1961, in which both leaders pledged to support a neutral Laos, Chen Yi studiously failed to give any credit to it. ${ }^{53}$ Compared to China and Russia, North Vietnam played a minor role at Geneva-much less influential than at the 1954 Conference, where it had directly represented the Pathet Lao in negotiating the cease-fire agreement with France. North Vietnam was excluded from the Drafting Committee and the crucial informal meetings among major powers.

It was a vital part of China's negotiating tactics that, being aware of the intrinsic relationship between the Geneva Conference and the tripartite talks and between negotiations and hostilities, the Chinese delegation exploited the military and political development of Laos as an important instrument of its diplomacy at Geneva. To solve such difficult issues as SEATO's role and military integration, the Chinese relied on the decisions among the Laotian groups, which they could manipulate more confidently than the Geneva Conference itself. For this purpose the Chinese kept close contacts with Princes Souvanna Phouma 
and Souphanouvong and gave them unreserved support in the face of Boun Oum, whose relationship with the United States was often confused. As the cease-fire was never effective throughout the Conference, the Chinese assisted the Pathet Lao's intermittent military efforts to gain a favorable position, which they used to compel the reluctant adversaries to make concessions. They indeed said that negotiations did not decide anything but recorded historic forces and that no one could get at the conference what was lost at the battle ground.

With the needs of a policy for the future in mind, the Chinese immediately undertook a systematic evaluation of the Geneva settlement in the context of their double-edged struggle against "imperialism" and "modern revisionism." Perhaps they wished to measure the practical compromise against their ideological standards and redefine their positions in historical perspective. From their Geneva experiences the Chinese extracted another "proof" to justify their ideological argument that the support for national liberation struggles was an imporant component of the world peace movement and that the peaceful solution of the Laotian questions was secured by the Laotian people's "serious, complex, and principled" struggle. ${ }^{54}$

In their theory of anti-imperialist struggle the Chinese preached a simultaneous military and political struggle. Consistent with their historical experience, however, they gave priority to the military struggle as prerequisite to attaining political objecives. They explained that only when the American "imperialists" and Laotian "reactionaries" suffered military failures were they forced to attend the negotiations and accept the agreements. This was a clear warning against any illusions of the "modern revisionists" who might simply place the ultimate hope for world peace on negotiations alone. In the context of China's domestic revolutionary struggle Mao Tse-tung once explained:

Everything reactionary is the same; if you don't hit it, it won't fall. This is also like sweeping the floor; as a rule, the dust will not vanish of itself . . . . Broom in hand, you must learn to sweep; don't lie in bed, fancying that a gust of wind will somehow rise and blow all the dust away. We Marxists are revolutionary realists and never indulge in idle dreams. ${ }^{\mathbf{5 5}}$

Accordingly, the Chinese said that as the imperialists and reactionaries would never give up their aggressive intentions but would always stand ready to destroy the agreements which they were forced to accept, continuing vigilance and preparedness were required in defense of such 
agreements and in the "tit-for-tat struggle" against the revival of imperialist aggression.

Although the Geneva Conference broke a "link in the chain of tensions" which the United States had forged around China's periphery, the Chinese emphasized that this achievement was merely temporary. In an authoritative article in Hung-ch'i, "Yu Chao-li" analyzed the "real" calculations of U.S. policy in Southeast Asia: first, by signing the Geneva agreements, the United States temporarily turned the military struggle in Laos into a political one so as to avert complete military defeat and maintain its control over Lower Laos and areas along the Mekong River, while awaiting opportunities to regain control over the whole of Laos; second, the U.S. retained its aggressive forces in Thailand in order to suppress the Thai people and support its eventual invasion into Laos and South Vietnam; and, third, the U.S. concentrated its efforts on accelerating the undeclared war in South Vietnam. ${ }^{56}$

$\mathrm{Yu}$ predicted that the United States would surely adopt various forms of political conspiracies in Laos in violation of the Geneva agreements: the U.S. would destroy the unity of the patriotic Laotian forces, strengthen the right-wing military power, produce a pretext for creating a pro-American government in Vientiane, limit the Pathet Lao's political freedom, and instigate armed disturbances in the "liberated areas." If these conspiracies failed, he added, the United States would "openly destroy the Geneva agreements, rekindle Laotian civil war, and even dispatch, directly, an army into Laos." The publication of these detailed prognoses was apparently intended to dispel any wishful thinking about the viability of negotiated settlements with the United States, and also to provide the Pathet Lao leaders with a policy guideline in the wake of the Geneva accords. Likewise, at a reception for Phoumi Vongvichit (the Pathet Lao's chief negotiator at Geneva), Chou En-lai said that the Laotian people should prepare themselves for the beginning of a new struggle against American "imperialists" and Laotian "reactionaries." 57 This advice undoubtedly reflected Chou's own experience of negotiations with the Kuomintang and the United States, full of turns and twists and violations and breaches of confidence.

For a while some observers considered the negotiated settlement of Laos applicable in other troubled countries in Asia. In August, 1962, Prince Sihanouk asked the signatories of the Laos agreements to hold 
a similar international conference on Cambodia and guarantee its neutral status and territorial integrity. In his immediate reply to Sihanouk, Chou En-lai supported such a proposal..$^{58}$ And, in July and August, the National Liberation Front of South Vietnam made it clear that it was ready to include South Vietnam in a "peaceful and neutral zone" with Laos and Cambodia. "Following signature of the Geneva agreement on Laos," Edgar Snow observed, "it became obvious that China as well as Hanoi had begun to place greater credence in possibilities of a similar solution in Vietnam." ${ }^{59}$

But it was evident that at the conclusion of the Geneva Conference the Chinese had already made the worst possible assessment about the future of the agreements. So long as the United States continued to preserve its military commitments in South Vietnam and Thailand and pursued its containment policy in Southeast Asia, they had no reason to assume that the Geneva formula would work or that their own interests would be greatly promoted. Nor did they find any reason to think that the precarious structure of the Laotian coalition would function well, especially in such complicated areas as the integration of military and administrative units, the development of democratic practices, and the maintenance of a genuine neutral policy. In the meantime the Chinese devoted their main attention to effecting complete withdrawal of U.S. military personnel from Laos and to concluding diplomatic relations with Vientiane. And they were apparently in the process of making proper preparations for all contingencies that might arise from the possible failure of the 1962 modus vivendi.

\section{Notes}

1. For a detailed description of the coup, see Dommen, Conflict in Laos, op. cit., pp. 142170, and Sisouk Na Champassak, Storm Over Laos, op. cit., pp. 154-168.

2. See the policy statement of the Revolutionary Committee in Yin-tu-chih-na-wen-t'i-wenchien-hui-pien, Volume III [Collected Documents Concerning Problems in Indo-China] (Peking: 1961), pp. 62-65. (Hereinafter referred to as Yin-chih-wen-chien.)

3. For his message of September 3, see Peking Review (September 14, 1960), p. 41.

4. People's Daily, September 5, 1960.

5. Department of State Bulletin (September 26, 1960), p. 499.

6. Yin-chih-wen-chien, op. cit., pp. 91-93.

7. People's Daily, November 21, 1960.

8. This does not mean that, as Crozier observes, China "had fairly consistently taken a curiously detached view of Laotian problems" until December, 1960, and shown a "longstanding indifference to Laos." (See Brian Crozier, "Peking and the Laotian Crisis: An Interim Appraisal," China Quarterly, July-September, 1961, p. 129, and "Peking and the Laotian Crisis: A Further Appraisal," ibid., July-September, 1962, p. 123.) Careful examination of People's Daily from September 1 to December 31,1960, suggests that although it did not show any significant initiative on China's part, People's Daily itself made a reasonably 
attentive and comprehensive coverage on Laos-domestic political development, military situations, foreign affairs, etc. About 16 issues of People's Daily reported on Laos in September, including one "Observer's" comment; 23 issues in October; 20 issues in November, including one commentary and one editorial (one of seven editorials on foreign affairs that People's Daily carried during November); and almost every issue in December, including one commentary and two editorials.

9. Yin-chih-wen-chien, pp. 109-110, 123-124.

10. Edgar Snow compared the episode to Khrushchev's similar intentions behind the Berlin Wall, The Other Side of the River: Red China Today (New York: Random House, 1962), p. 662.

11. See exchange of statements between Hanoi (December 17) and Peking, People's Daily, December 20, 1960.

12. Yin-chih-wen-chien, pp. 123-124.

13. Nehru said on December 20 that the Commission's reactivation should receive a consent from the Vientiane authorities (i.e., Boun Oum's government) and that it was difficult to know "who is the government and who is the rebel," in Richard Gott (ed.), Documents on International Affairs 1960 (London: Oxford University Press, 1964), pp. 526-527.

14. See J. Chester Cheng (ed.), The Politics of the Chinese Red Army (Stanford: Hoover Institution, 1966), pp. 366-367.

15. Quoted in Roger Smith, "Cambodia's Neutrality and the Laotian Crisis," Asian Survey (July, 1961), p. 22.

16. Department of State Bulletin (January 16, 1961), p. 76.

17. Arthur M. Schlesinger, Jr., A Thousand Days: John F. Kennedy in the White House (Boston: Houghton Mifflin, 1965), pp. 163-164.

18. Department of State Bulletin (February 13, 1961), p. 210.

19. See Cheng, The Politics of the Chinese Red Army, op. cit., pp. 367-369.

20. Yin-chih-wen-chien, pp. 162-163.

21. See Peking Review (February 24, 1961), pp. 8-9; and for the U.S. draft of Savang Vatthana's statement, see Schlesinger, op. cit., p. 330.

22. Department of State Bulletin (April 17, 1961), pp. 543-544.

23. It was also communicated to Moscow through Home, Nehru, and Ambassador Llewellyn

N. Thompson. See Theodore C. Sorensen, Kennedy (New York: Bantam, 1966), pp. 724-725.

24. Peking Review (April 14, 1961), p. 5.

25. Kenneth T. Young, "American Dealings with Peking," Foreign Affairs (October, 1966), pp. 81-82.

26. Department of State Bulletin (May 15, 1961), pp. 710-711.

27. Chieh-chueh-lao-chua-wen-t'i-k'uo-ta-t'i-jih-nei-wa-hui-i-wen-chien-hui-pien [Collected

Documents on the Enlarged Geneva Conference for the Settlement of the Laotian Question]

(Peking: 1962, hereinafter referrd to as Lao-chua-wen-chien), pp. 367-369.

28. Ibid., pp. 25-26.

29. People's Daily, May 9, 1961.

30. In support of Boun Oum's position both Thailand and South Vietnam did not attend the opening session of the Conference. On May 24, Thanat Khoman sponsored Phoui Sananikone and Tiao Somsanith to be present at Geneva, but the Conference rejected it. Only on June 27 did Phoui Sananikone, representing the Vientiane "neutralists," start attending the Conference.

31. As to the number of Chinese delegates and their activities at Geneva, see Arthur Lall, How Communist China Negotiates (New York: Columbia University Press, 1968), pp. 1-3.

32. Lao-chua-wen-chien, pp. 46-51.

33. Ibid., pp. 51-57.

34. United States Outlines Program To Insure Genuine Neutrality for Laos (Washington: USGPO, 1961), p. 6.

35. Lao-chua-wen-chien, p. 70.

36. See Chauvel's May 23, 1961, proposal and Harriman's June 20, 1961, proposal, in ibid., pp. 242-250.

37. Chen Yi's June 26, 1961, speech and Chang Han-fu's August 21, 1961, statement, ibid., pp. 70,93 .

38. Chang's September 5, 1961, speech, in Chung-hua-jen-min-kung-ho-kuo-tui-wai-kuanhsi-wen-chien-chi, Volume VIII [Documents on Foreign Relations of the Chinese People's Republic] (Peking: 1962, hereinafter referred to as Tui-wai-wen-chien (Vol. 8)), pp. 109-110.

39. It is difficult to agree with Hinton's assessment that "the non-Communist participants succeeded in strengthening somewhat the degree of international supervision, and in particular the powers of the restored ICC," Harold C. Hinton, Communist China in World Politics (Boston: Houghton Mifflin, 1966), p. 348. 
40. At Moscow, however, M. Yegorov made a reference to the "U.S.-equipped bands of Chiang Kai-shek" used on a big scale in Laos, "The Geneva Conference on Laos," International Affairs (Moscow: September, 1961), pp. 38-44.

41. For an analysis of this issue, see John J. Czyzak and Carl F. Salans, "The International Conference on the Settlement of the Laotian Question and the Geneva Agreements of 1962," American Journal of International Law (April, 1963), p. 308.

42. See Chang Han-fu's August 4, 1961, statement, George Modelski, International Conference on the Settlement of the Laotian Question 1961-2 (Canberra: Australian National University, 1962), p. 110.

43. See Chang's July 6, 1961, speech, Lao-chua-wen-chien, pp. 78-81, and his July 26, 1961, speech, Tui-wai-wen-chien (Vol. 8), op. cit., p. 86.

44. See Modelski, op. cit., pp. 134-135. In an interview with me in October, 1967, Ambassador Sullivan recalled that the Chinese had been "clumsy" and "inflexible" at Geneva.

45. For these questions, see "Gunfire Drowns Talk of Peace," Peking Review (February 2, 1962), p. 10; "The Continuous Double-faced Tricks of the U.S. in Laos," Shih-chieh-chih-shih [World Knowledge] (March 10, 1962), pp. 2-3; Peking Review (July 14, 1961), p. 13; and Hsinhua News, March 24, 1962.

46. See the statements of Kennedy and SEATO, Department of State Bulletin (June 4, 1962), pp. 904-906; Britain sent to Thailand a Hunter jet-fighter squadron, Australia dispatched a jet-fighter squadron, and New Zealand a Special Air Service Battalion.

47. People's Daily, May 16 (commentary) and May 19 (editorial), 1962.

48. Lao-chua-wen-chien, pp. 353-356.

49. See exchange of messages between Chen Yi (on June 23) and Foreign Minister Quinim Pholsena (on June 25), ibid., pp. 432-433.

50. Modelski, op. cit., pp. 31-32; also see Czyzak and Salans, op. cit., p. 309.

51. Department of State Bulletin (August 13, 1962), pp. 259-263, or Lao-chua-wen-chien, pp. 2-11.

52. The Drafting Committee was first set up on July 26, 1961, with Britain, Russia, France, India, and China, and was joined on August 16 by America, Canada, and Poland. Fournation and six-nation informal talks were mainly concerned with exchange of different views and reconciliations. The Chinese delegation held a number of receptions at Geneva, including one for all members of the Geneva Conference (except the U.S. and South Vietnam).

53. For Kennedy-Khrushchev talks at Vienna, see Sorensen, op. cit., p. 729, and Modelski, op. cit., pp. 60, 68, 140 .

54. People's Daily editorial, July 24, 1962.

55. "The Situation and Our Policy After the Victory in the War of Resistance Against Japan" (August 13, 1945), Selected Works of Mao Tse-tung, Volume IV (Peking: FLP, 1961), pp. 19-20.

56. "The Great Victory of the Laotian People," Hung-ch'i (September 16, 1962), pp. 1-8.

57. Peking Review (August 3, 1962), p. 17.

58. See exchange of messages between Sihanouk (on August 20,1962) and Chou (on August 27), in Yin-tu-chih-na-wen-t'i-wen-chien-hui-pien, Volume IV [Collected Documents Concerning Problems in Indo-China] (Peking: 1964), pp. 319-321, 322-323.

59. Snow, op. cit., p. 707. 


\section{Chapter V \\ The Chinese Policy of Reappraisal After The Geneva Conference}

Section One: Development of the Second Geneva Formula

In the aftermath of the second Geneva Conference the Chinese were most deeply concerned with two crucial issues-the withdrawal of U.S. forces from Laos and the establishment of diplomatic relations with Vientiane. The first logical step toward international neutralization of Laos was the withdrawal of all foreign military personnel within the 75-day time limit (October 7, 1962) under the control and supervision of the International Control Commission. The Chinese were especially anxious to see the withdrawal go as planned in order to establish a precedent for eventually urging the voluntary pull-out of foreign units from Thailand and South Vietnam. They thought that so long as the United States maintained its military forces in these two countries with the manifest purpose of containing Asian Communism, neither the peaceful settlement of Laos nor the national security of China could effectively be guaranteed.

In accordance with this military analysis the Chinese promptly started a verbal attack against the continued presence of U.S. forces in Southeast Asia. On August 1, 1962, Foreign Minister Chen Yi reiterated his Geneva demand that the United States withdraw its armed forces from Thailand and South Vietnam to ease tension in Southeast Asia and to allow Asians to solve their own problems. ${ }^{1}$ U.S. forces in these countries, argued a "Commentator" in People's Daily (August 21, 1962), were intended to hem Laos in, thus threatening its neutral status. With the approach of the withdrawal deadline the Chinese stepped up their campaign to impress Washington with how seriously they regarded complete military evacuation and to arouse international public opinion in favor of their position. At diplomatic receptions held in Peking in August, by the Indonesian Ambassador and by the Rumanian Ambassador, Chen Yi repeatedly warned against the possibility that the United States and its "vassal countries" would evade the obligation to withdraw their troops from Laos. He also accused the United States 
of instigating General Phoumi Nosavan to sabotage the coalition government and to disturb the Pathet Lao's "liberated areas."

Meanwhile, the Chinese were vigorously working to establish permanent diplomatic relations with Laos. Since 1954, their efforts in this direction had proved difficult. Only in the second Sino-Laotian joint statement signed in April, 1961-during the civil war in Laos-did Chou En-lai and Souvanna Phouma agree to establish diplomatic relations and to exchange diplomatic missions of the rank of ambassadors. The Chinese interpreted this agreement not merely as a "solid foundation" for furthering Sino-Laotian cooperation, but as a "heavy blow to the U.S. imperialist scheme to sow discord and undermine friendship and solidarity among the Asian peoples." 3 Moreover, the two Governments took steps toward exchanging economic and cultural missions. In October, 1961, they agreed to set up consulates-general at Phong Saly in Laos and at Kunming in China's Yunnan Province, thus counterbalancing the earlier Taipei-Vientiane consular agreement of 1958. As the new Chinese Consul, General Ting Yung-cheng (ex-commander of the Kunming Military District) arrived at Phong Saly with his staff on October 17; two months later, the Lao Consul reached Kunming. And in November, the Chinese Economic and Cultural Mission headed by Ho Wei (ex-Ambassador to Hanoi and veteran of the Long March) and Liu Ch'un was welcomed by Souvanna Phouma and Souphanouvong in Xieng Khouang. This Mission carried on semidiplomatic functions in the "liberated areas" until September, 1962. For example, on behalf of the CPR, it signed agreements concerning the construction of a highway and the opening of a civil air route between China and Laos.

As soon as a new coalition government was formed in Laos on June 23, 1962, Chen Yi announced Chinese recognition and proposed to exchange ambassadors; new Lao Foreign Minister Quinim Pholsena promptly accepted this proposal. But a few days later the Boun OumPhoumi Nosavan group belatedly announced a royal edict of June 18, 1962, appointing a Laotian Ambassador to Taiwan. Such a move was intended to legalize the appointment technically made five days prior to the inauguration of the coalition government. As a result of the visit of Boun Oum and Phoumi Nosavan to Taipei in May, 1962, they had concluded an agreement with Nationalist China for exchanging 
ambassadors. Accordingly, on June 28, Chiang Kai-shek announced the appointment of Dr. Hang Li-wu as Nationalist Chinese Ambassador to Laos. When Hang presented his credentials to King Savang Vatthana in July, the CPR was faced with the difficult question of what to do with its own diplomatic representative, Liu Ch'un, who had arrived in Vientiane on July 11.

Thereupon the CPR, as a precondition of full diplomatic relations between Peking and Vientiane, asked the RLG to remove the Nationalist Chinese Ambassador from Laos and to terminate all ties with Taiwan. At a press conference held in Vientiane Liu Ch'un made it clear that "any mission established by the Chiang Kai-shek clique, usurping the name of China, and any activities undertaken by it are absolutely illegal." ${ }^{4}$ Even a personal confrontation took place between Liu and Hang in August, when Premier Souvanna Phouma arrived at the airport from his trip abroad. As Souvanna Phouma approached Hang in the diplomats' line, Liu abruptly stood between the two and claimed that he, not Hang, was representing 650 million Chinese people. After this embarrassing episode, Taiwan, under intense pressure from Quinim Pholsena, finally decided on September 7 to sever diplomatic relations with Laos. On the same day the CPR, in a joint statement with the RLG, formally announced the exchange of diplomatic missions between the two Governments. ${ }^{5}$

This major diplomatic breakthrough, the result of the 1962 Geneva settlements, left Bhutan as the only independent state on China's border that did not extend de jure recognition to the CPR. As Peking's first Ambassador, Liu was a Deputy Director of the United Front Work Department of the Chinese Communist Party Central Committee, presumably with experience in working with united fronts such as the one involved in Laos. He had also held a number of important positions: Vice-Chairman of the Nationalities Affairs Committee of the State Council, member of the Central Committee of the Chinese Peasants' and Workers' Party, member of the Nationalities Committee of the third National People's Congress, and President of the Central Nationalities College in Peking. As an expert in minority problems, he was evidently chosen with an eye to the problems of multi-ethnic relations in Laotian politics. The attention which the Chinese accorded to the strategic aspect of minorities was also reflected in the selection of other 
Chinese personnel for Laos; Han Chinese occupied the key posts in the Embassy while the Chinese advisers in the Plain of Jars area were selected from among those Chinese cadres of the same ethnic stock as the several Laotian minorities. The initial diplomatic harmony between Peking and Vientiane led to the visits to China of Vice-Premier Phoumi Nosavan in December, 1962, and of King Savang Vatthana and Premier Souvanna Phouma in March, $1963 .{ }^{6}$

After the final date for the withdrawal of foreign forces, the International Commission reported in October, 1962, that its checkpoints had verified the evacuation of 40 North Vietnamese, 666 Americans, and 403 Filipinos. ${ }^{7}$ The report failed to quiet Peking's obsession with the presence of Kuomintang irregular forces but the CPR refrained from challenging either the Commission's statistics or the omission of any reference to the Kuomintang forces. However, Peking's dissatisfaction was indirectly expressed by General Singkapo Chounlamany, the Pathet Lao's spokesman, who said that about 3,000 Kuomintang troops and some of Thai, South Vietnamese, and Japanese military personnel still remained in Laos in contravention of the Geneva provisions. ${ }^{8}$ While the CPR and the NLH were disillusioned about the complete withdrawal of pro-U.S. foreign forces, both America and Britain were in their turn suspicious of Hanoi's assertion that North Vietnamese personnel formerly in Laos at the request of the RLG had been completely evacuated. On October 11, the United States declared that it would not passively accept the continued presence in Laos of North Vietnamese soldiers-estimated by U.S. intelligence to number several thousands. ${ }^{9}$

The dispute over military evacuation only served to exacerbate the profound and long-standing suspicions between Peking and Washington. Indeed the issue revealed that the minimum degree of good faith essential to ensure a lasting peace in Laos was lacking. The mutual dissatisfaction with the execution of the Geneva provisions on other military questions led to a further Sino-American exchange of accusations and recriminations. Both Washington and Peking viewed with serious concern the question of how to integrate the separate armed forces of the three Laotian factions, thus terminating de facto military division of the country. Although the presence of these forces was more a symptom than an intrinsic cause of the conflict in Laos, their unification within a single command structure was a sine qua non to Laos' 
unification and neutralization. But early records of the tripartite coalition experiment proved irrefutably that the requirement of unanimity among the three factions precluded effective policy formulation, including military integration. Any unity of purpose or resolution which the coalition might have had was from the first undermined by the prevailing suspicions and the clash of interests, ideologies, and personalities which inevitably smoldered in the aftermath of a long and bitter fratricidal conflict. Each party remained in control over its own army and area; Phoumi Nosavan continued to prevail in the administrative capital and the Pathet Lao in the "liberated areas." Later, in September, 1963, Souvanna Phouma complained at the United Nations that "a very reticent collaboration between members renders the coalition most precarious. Bitter and constant criticism prevents full cooperation. Very often some elements remain stubbornly set in a suspicious attitude and others try to prevent negotiation by creating and multiplying obstacles along the way." 10

In order to block any Western attempt to consider the question, the Chinese, in cooperation with Hanoi and Moscow, had argued that military integration was a purely domestic problem. Only in the Zurich agreement had the three Laotian leaders agreed in principle to unify their armed forces into a single National Army according to a program to be approved by the parties concerned. In November, 1962, the three parties agreed to form a unified National Army of 30,000 men, a National Police of 6,000, and a Vientiane Police of 1,200. These forces would be drawn equally from the three parties, which, in turn, would substantially reduce their respective forces. At the time of the Laotian cease-fire the number of right-wing forces was estimated at about 55,000, the Pathet Lao forces at 18,000, and the neutralist forces at $12,000{ }^{11}$

In January, 1963, the Laotian leaders instructed the Joint Commission of Military Unification to hasten the discussions for setting up the program and conditions of demobilization; they also told the Joint Commission of Administrative Unification to expedite the organization of the joint police in Vientiane. They also reaffirmed the principle of unanimous agreement in all important questions concerning the Ministries of Defense, Interior, and Foreign Affairs. Finally they decided to eliminate all derogatory and rude expressions or accusations aimed at members of the National Union Government. ${ }^{12}$ While these develop- 
ments were occuring in Laos, the Chinese remained aloof but kept a vigilant eye on questions vital to the future of the Pathet Lao revolutionary struggle. If the Pathet Lao sought their advice on military matters, the Chinese either discouraged the unrealistic hope of military integration or counseled extreme caution against being maneuvered into a trap like that of 1959 . For it is unlikely that the Chinese would have forgotten Mao's dictum, "political power grows out of the barrel of a gun," or the failure of the Pathet Lao's first integration experiment. ${ }^{13}$

When the two military problems crucial to the neutralization of Laos continued unsolved into early 1963, the Chinese, abandoning their policy of relative silence, started to attack the U.S. policy toward Laos. Following the evacuation of military advisers, the United States cut back its financial support of Laos as well. But it soon decided, at the Premier's request, to supply maintenance material for the armed forces of Kong Le and Phoumi Nosavan. The Chinese responded by charging that the United States, in complete violation of the Geneva provisions, had continued to pour military supplies into Laos and expanded Phuomi Nosavan's army from 54,000 in July, 1962, to 63,000 in January, 1963. Going on to further "crimes," they charged that the United States had constructed secret military bases in Laos, flown reconnaissance missions over the "liberated areas," maintained 900 of its military personnel in the country, and conducted through the C.I.A. the Air America operation-a "paramilitary organization" which dropped weapons and munitions to the anti-Communist Meo tribesmen. ${ }^{14}$ In an article in Peking Review (February 8, 1963), Fang Ming further accused the United States of switching a considerable number of its military personnel into mufti to serve as "non-military" members of its Embassy at Vientiane and of other "economic and cultural" agencies. He asserted that the U.S. missions in Laos, such as the Agency for International Development (USAID), the United States Information Service (USIS), the Organization of Medical Services, and Air America, were serving as "American Trojan horses," all operating for subversive purposes. ${ }^{15}$ By early 1963, therefore, the Chinese had accumulated enough "evidences" to substantiate Yu Chao-li's earlier prediction and to conclude that the military preconditions for neutralization of Laos could not be achieved in the face of the relentless U.S. policy there. 
Laos' neutrality was based upon a number of assumptions concerning its future domestic political configuration. These included the emergence of a viable coalition government of three distinctive political groups, the tactful use of balancing power by the neutral group of Souvanna Phouma, and the recognition by the major states concerned of the legality of the RLG. In less than a year, however, these domestic prerequisites of the Geneva agreements were being eroded by a combination of forces-especially, a resurgence of the anti-Communist feeling of the kind that led to Phoui Sananikone's systematic anti-Communist measures of 1959. The deterioration in relations among the three groups, hastened by the assassination in April, 1963, of Foreign Minister Quinim Pholsena, reached a point of no return in the coup d'état of the right-wing generals in April, 1964. Thus, the internal foundation of the second Geneva modus vivendi was gradually but irrevocably destroyed.

The death of the ostensibly neutral but, in reality, pro-Peking Quinim Pholsena and its subsequent repercussions held some important political implications. ${ }^{16}$ For Peking it meant the loss of a very useful and influential leader in the RLG, a man instrumental in building diplomatic cooperation between the two countries. Domestically, his death deepened the schism between Quinim Pholsena's "progressives" and Souvanna Phouma's "conservatives" within the neutralist group and shifted the inter-factional balance in favor of the conservative faction. This intensified the military conflict between Kong Le's conservative neutralist forces and Col. Deuane Siphaseuth's progressive neutralist dissidents in the Plain of Jars and produced a tendency towards a bipolarization of Laotian politics in the formation of two antagonistic military alliances-one between Kong Le and Phoumi Nosavan and the other between Col. Deuane and the Pathet Lao.

This bipolarization-splitting the neutralist group into two hostile factions which then each merged with one of the extreme groups-ran counter to a basic political assumption of the Geneva settlement. The disappearance of an independent, viable, and unified third group seriously undermined Premier Souvanna Phouma's leadership and made the tripartite coalition unthinkable. After a series of political assassina- 
tions and armed clashes Vice-Premier Souphanouvong and Phoumi Vongvichit (Minister of Information, Publicity, and Tourism), perhaps mindful of their arrest in Vientiane in 1959 by Phoui Sananikone, left the capital to set up their NLH headquarters at Khang Khay. The two NLH Secretaries of State, Souk Vongsak and Khampheuane Tounalom, remained in Vientiane for a while to represent the NLH at the coalition.

The assassination of Quinim Pholsena, the cleavage of the neutralist group, the breakdown of the coalition, and the violation of the cease-fire agreement-all of these developments in Laos affected the Chinese task of guaranteeing the Geneva agreements and defending the Pathet Lao's revolutionary interests. After Chou En-lai sent condolences to Premier Souvanna Phouma on Quinim Pholsena's death, China charged that the United States had provoked the recent political murders and military conflicts to subvert the coalition and rekindle civil war in Laos. When the Laotian Ambassador to Thailand countercharged that two Chinese Communist regiments had occupied the northern town of Muong Sing since March, 1963, the Chinese Government issued a statement on April 16, attacking U.S. "aggression" and "intervention" in the domestic affairs of Laos. It said:

U.S. imperialism had never ceased its scheming activities of infringing on Laotian sovereignty, interfering in Laotian internal affairs and undermining Laotian peace and neutrality ever since the formation of the Laotian Government of National Union and the conclusion of the Geneva agreements . . . . The purpose of U.S. imperialism is precisely to intimidate and disintegrate the Laotian neutralist forces, and sow dissension in the relations of unity and cooperation between the neutralist group and the Neo Lao Haksat. ${ }^{17}$

In order to arrest the downward trend of Laotian events, the Chinese requested the Geneva Co-chairmen to take "necessary measures" against the increased American intervention in Laos. This tactic-a common one in Chinese Laotian policy-was meant to achieve one of two objectives: either to restrain further American involvement in Laos or to shift to the Co-chairmen partial responsibility for the deteriorating situation. China also suggested that the Co-chairmen call the Conference if the United States persisted in its aggressive policy in Laos. By this proposal the Chinese acknowledged that the 1962 Geneva formula could not operate without being substantially recast at another international parley. Their proposal also showed that they considered 
a Geneva type of conference a useful platform in their campaign against the United States. As early as April 11, United Nations Secretary-General U Thant had made a similar proposal. But, unlike Dag Hammarskjold, U Thant showed himself reluctant to get the United Nations involved in Laos. Noting that neither China nor North Vietnam were members of the United Nations, he said he did not see how the U.N. could be usefully and effectively involved in finding a solution to the Laotian problem. $^{18}$

While the Chinese strengthened their diplomatic offensive, they were increasingly alarmed by overt military measures undertaken by the United States in Laos. The U.S. had already supplied Kong Le's army with arms and war materials to help him maintain his "defensive capacity." The Chinese claimed that the United States had, in addition, granted more than $\$ 30$ million military aid to Phoumi Nosavan and expanded his armed forces. They devoted considerable attention to a series of military maneuvers conducted by the U.S. and its allies around Laos. These included the Thai-South Vietnam joint military demonstration along the Laotian border, the dispatch of the U.S. Seventh Fleet to the Gulf of Siam, and other exercises involving SEATO powers in the South China Sea and U.S. airplanes in the Philippines.

Deeply conscious of the growing American encroachment upon Laos and Vietnam, the Chinese attempted to coordinate an anti-American policy with North Vietnam and to compete with Russia's moderate Indo-China policy. During May, Chairman Liu Shao-ch'i conferred with Ho Chi Minh in Hanoi and signed a joint declaration of "intense concern" over the grave situation in Laos. ${ }^{19}$ The Chinese demanded once again that the Geneva Co-chairmen take "effective emergency measures" to check U.S. imperialist aggression in Laos and to remove the threat to Laos' neutrality. They made their diagnosis clear, butexcept for a reference to the Co-chairmen's desired role-left their remedy vague. The Liu-Ho statement failed to discuss the possibility of further negotiations, including Chen Yi's previous suggestion for another international conference. It was doubtless feared that a strong call for negotiations would be construed as a sign of weakness in the face of the increasing tension in Laos. Moreover, in early May, Souvanna Phouma and Souphanouvong, unable to reach any constructive agreement in their three-day negotiations at Khang Khay, only traded 
mutual accusations. ${ }^{20}$ In reality the Chinese had already recognized the failure of their initial diplomatic maneuvers; therefore, they decided to assist the Pathet Lao's limited armed operations unobtrusively.

With civil war renewed in Laos, Souvanna Phouma was forced to rely on the International Commission's peacekeeping authority. When he requested the Commission's assistance in arranging a cease-fire in the strategically important Plain of Jars in April, 1963, the Indian Chairman Avtar Singh joined the Canadian delegation in sending a permanent inspection team to Kong Le's headquarters in the Plain despite the protests of the NLH and the Polish member of the Commission. This was the first time the Polish delegation boycotted the Commission's important operation, thereby showing the intrinsic weakness of the international control mechanism. Except for supervising the withdrawal of foreign forces, the Commission had indeed done little since the conclusion of the second Geneva Conference. As a Western observer aptly said, "With limited men, and even more limited means of communication, divided ideologically, and lacking any authority its task is hopeless." ${ }^{\text {"1 }}$

The Commission's permanent team became a convenient object of strong Chinese opposition. They called it illegal on the ground that it overstepped the Commission's terms of reference and lacked the required full cooperation of the Polish member and of the coalition government. In a Foreign Ministry statement the CPR called upon the Geneva Co-chairmen to dissolve the team immediately. ${ }^{22}$ The Soviet Union, too, pointed out the illegality of the Commission's team in the Plain of Jars, but avoided any outright denunciation of the Commission or its Indian and Canadian members. Foreign Minister Gromyko, evidently unhappy with the renewed fighting in Laos, issued a joint appeal with the British Co-chairman on May 29, asking the warring factions in Laos to effect an immediate truce and thus allow the Commission to initiate its activities. Both Co-chairmen, clearly intending to use the Commission to settle the armed conflict, endorsed its proposal for restoring what had been the status quo prior to June, 1962. As the proposal required the Pathet Lao to give up all the territory won since that time, it was certainly unacceptable to Souphanouvong as well as to his Asian Communist supporters.

The relationship between the CPR and the Commission declined 
to a new low when the direct conflict of interests between China and India intensified in Laos and elsewhere. For example, in a note to the RLG, the Indian and Canadian members of the Commission proposed to investigate a report that some Chinese troops had been found in northern Laos. The Chinese responded with an "authorized" statement by the Hsinhua News Agency (June 6) that such an allegation was simply an out-and-out lie. The Indian and Canadian members, they said, had been "willing tools of U.S. imperialism in its aggression and intervention in Laos." The Commission, they further asserted, had repeatedly submitted to the Co-chairmen reports distorting the Laotian situation and slandering the Democratic Republic of Vietnam and the Chinese People's Republic. ${ }^{23}$ This severe criticism also challenged the qualifications of Commission Chairman Avtar Singh. The Chinese bluntly argued that he had failed to carry out his responsibilities in a fair, impartial way. In line with Chinese moves, the Pathet Lao frustrated the Commission's efforts for inspection and investigation, even shooting at the Commission's helicopters flying over the "liberated areas."

Both China and North Vietnam refused to help the Commission solve its financial difficulties. At the second Geneva Conference the five principal powers-America, Britain, China, France, and Russia-had assumed all of the pre-accord expenditures of the Commission (April, 1961-July, 1962) and most of its post-accord expenditures (July, 1962June, 1963). As Table 5 shows, China was the only principal power which did not pay in full its share of the pre-accord and post-accord expenditures. North Vietnam did not fulfill its financial responsibility at all, while both Russia and Poland paid their shares in full. ${ }^{24} \mathrm{By}$ withholding these funds, both China and North Vietnam expressed their dissatisfaction with the way the Commission had been "misguided" by the Indian Chairman and hindered the Commission from replacing its two damaged helicopters.

This systematic challenge to the Commission embarrassed both the United States and the Soviet Union, both of which attempted to preserve the Commission's normal supervisory and investigative function as the only possible way within the framework of the Geneva accords of helping keep the peace. The United States in particular was satisfied to see the Commission's "demonstrable value" and "important effect" 
TABLE 5

The International Commission: Status of Financial Contributions as of JANUARY, $1964^{\mathrm{a}}$

\begin{tabular}{|c|c|c|c|c|c|}
\hline Country & $\begin{array}{l}\text { Assessed for } \\
\text { period April, } \\
\text { 1961, to July } \\
\text { 22, } 1962\end{array}$ & Paid & $\begin{array}{c}\text { Assessed for } \\
\text { period July } \\
23,1962 \text {, to } \\
\text { July } 30,1963\end{array}$ & Paid & Outstanding \\
\hline China & $\$ 450,000$ & $\$ 300,000$ & $\$ 665,280$ & $\$ 399,224$ & $\$ 416,056$ \\
\hline U.S.A. & 450,000 & 450,000 & 665,280 & 665,280 & $\ldots$ \\
\hline U.S.S.R. & 450,000 & 450,000 & 665,280 & 665,280 & $\ldots .$. \\
\hline Britain & 450,000 & 450,000 & 665,280 & 665,280 & $\ldots$. \\
\hline France & 450,000 & 450,000 & 665,280 & 665,280 & .... \\
\hline Laos & .... & .... & 56,700 & $\ldots$ & 56,700 \\
\hline Cambodia & $\ldots$. & .... & 56,700 & .... & 56,700 \\
\hline N. Vietnam & .... & $\ldots$. & 56,700 & $\ldots$. & 56,700 \\
\hline S. Vietnam & $\ldots$. & $\ldots$. & 56,700 & $\ldots$. & 56,700 \\
\hline Thailand & $\ldots$. & $\ldots$. & 56,700 & $\ldots$ & 56,700 \\
\hline Canada & $\ldots$. & $\ldots$. & 37,800 & $37,800^{b}$ & .... \\
\hline India & .... & .... & 37,800 & $37,800^{\mathbf{b}}$ & .... \\
\hline Poland & $\ldots$. & $\ldots$. & 37,800 & $37,800^{b}$ & $\ldots$. \\
\hline Total: & $\$ 2,250,000$ & $\$ 2,100,000$ & $\$ 3,723,300$ & $\$ 3,173,744$ & $\$ 699,556$ \\
\hline
\end{tabular}

a Source: International Commission for Supervision and Control in Laos: Hearing Before the Subcommittee on the Far East and the Pacific of the Committee on Foreign Affairs, House of Representatives (Washington: USGPO, 1964).

${ }^{\text {b }}$ Credited against amounts due supervisory powers.

in confining the Communists to minor military actions in Laos. As Assistant Secretary of State Roger Hilsman later testified at the House Foreign Affairs Committee, the United States acknowledged that the Commission's very presence had played an "essential role" in keeping the lid on in Laos and that the Commission's reports to expose Communist bad faith had contributed to increased free world support for Premier Souvanna Phouma. ${ }^{25}$ In fact, the Asian Communists were irritated by Souvanna Phouma's use of the Commission to protect his shaky authority and precarious government. In his notes to Chairman Avtar Singh and Lord Home during June, Souvanna Phouma charged that military operations of the Pathet Lao and its external allies, especially "Vietminh troops" within Laos, had made the cease-fire agreements practically null, and requested the Commission to investigate the matter closely. ${ }^{26}$

Meanwhile Pathet Lao representatives had maintained an uncertain life in a Vientiane under the control of General Siho Lamphoutacoul, a young protégé of Phoumi Nosavan and a powerful Chief of the Vien- 
tiane Bureau of National Security. Siho made even further attempts to strengthen his anti-Communist position in September, 1963. Taking advantage of a firing incident in Vientiane on September 9, his rightwing troops surrounded the residences of Pathet Lao representatives and fired at their security-guards. They also allegedly encircled the Embassy of North Vietnam and placed the personnel of the Chinese Embassy under surveillance. ${ }^{27}$

The Chinese viewed this episode as a premeditated attempt to force the remaining Pathet Lao representatives and their guards out of the tripartite coalition. Ambassador Liu Ch'un conveyed to Souvanna Phouma China's serious concern with the situation, one "extremely unfavorable" to the implementation of the Geneva agreements. But Liu's efforts proved fruitless and the conference among the three Laotian groups which was arranged by the Commission and the Co-chairmen broke down as well. After the disappointed Souvanna Phouma left the conference for the United Nations, Phoumi Vongvichit bitterly accused him of opportunistic politics and said he had moved so close to Phoumi Nosavan and away from the NLH that he was no longer neutral. In a series of comments and statements the Chinese endorsed Souphanouvong's proposal for neutralizing Vientiane and urged the Co-chairmen and the Commission to guarantee the freedom and safety of Pathet Lao personnel in Vientiane. Given the failure of the tripartite negotiations, the NLH organized a number of limited military maneuvers against the outposts held by Phoumi Nosavan and Kong Le. In October, the NLH Central Committee adopted a militant manifesto asking the Laotian people to increase their unity and alertness and to wage a resolute struggle against the United States and the Laotian "reactionaries."28 At the same time the United States warned against a significant increase in truck convoys carrying rice, fuel, ammunition, and arms from North Vietnam to the Pathet Lao forces. It was also noted with alarm that there were about 2,000-5,000 North Vietnamese soldiers within Laos. ${ }^{29}$

The tense political turmoil in Laos inevitably aggravated the relationship between the CPR and the Laotian right wing; as an exponent of the "two Chinas" idea, the right wing was regarded with hostility by Peking. Whenever the Chinese saw the slightest possibility that their diplomatic position might be compromised, they launched a forceful 
attack. They also utilized the "two Chinas" issue indirectly to secure the political influence necessary to check an anti-Communist upsurge in Vientiane. In October, 1963, when Phoumi Nosavan attended a Chinese National Day reception sponsored by pro-Chiang elements in Vientiane and when the RLG permitted some Overseas Chinese to visit Taiwan, Liu Ch'un protested these "incidents," calling them part of a U.S. scheme to create a "two Chinas" situation in Laos. ${ }^{30}$ Again in November, 1963, Liu Ch'un delivered a note to the Laotian Foreign Ministry protesting the "defamatory and slanderous" attack of Phoumi Nosavan, who said the CPR lacked sincerity in implementing the Geneva agreements and disrespected the sovereignty of Laos. Liu also protested the rightists' publication of a "forged document" maligning him personnally and accusing Peking of interfering in the internal affairs of Laos. ${ }^{31}$ Such "absolutely groundless" cases, he said, would not impair the CPR's prestige nor cause a change in its "impartial policy" toward Laos; they would merely show how the anti-Peking slanderers were serving the U.S. campaign against Peking. After reaffirming China's respect for the Geneva agreements and the principle of noninterference in the domestic affairs of Laos, Liu urged the RLG to respect in return the importance of the Sino-Laotian friendship and to take effective measures against the "mudslinging campaign" conducted by the right wing.

As the monsoon season (March-October) had permitted the Pathet Lao to secure some military gains, the Chinese, apparently hoping to preserve the military status quo during the dry season (NovemberFebruary), sent out peace feelers on the Laotian question. This was intended to forestall a possible counter-offensive by the right-wing forces who could use the dry weather to subject the Pathet Lao to air and artillery attacks. The Chinese were also apprehensive of the gradual American involvement in the "special war" against the National Liberation Front of South Vietnam (or "Vietcong") during 1963, and realized that any excessive military provocation by the Pathet Lao might precipitate a similar U.S. intervention in Laos. Thus, a commentator in People's Daily (November 15, 1963) suggested that the three parties in Laos could solve their own problems through negotiations provided the United States withdrew. Anxious to prevent a military escalation during the dry season, he also warned that the United 
States was plotting yet another "large-scale military venture" in that war-torn country. In spite of these predictions and warnings, China's policy at this time was clearly shifting from armed campaign to peaceful negotiations.

At the same time the Soviet Union was eager to bring about a peaceful condition in Laos. During Premier Souvanna Phouma's visit to Moscow from October to November, 1963, Khrushchev reportedly promised to persuade the NLH to cooperate with Souvanna Phouma, agreed to terminate the Russian oil supply to the $\mathrm{NLH}$, and supported a proposal for moving the administrative capital from Vientiane to Luang Prabang. In late November, the Soviet Government officially. stopped its military assistance program to the Pathet Lao and actively participated in the arrangements for a negotiated settlement in Laos. ${ }^{32}$

A month later the NLH Secretary-General Phoumi Vongvichit and Souvanna Phouma's representative, Sisoumang Sisaleusak, could meet and reach an important agreement. They decided to demilitarize Luang Prabang, create a tripartite mixed police force there, and transfer the administrative capital from Vientiane to Luang Prabang. ${ }^{33}$ Accompanied by the Soviet and British Ambassadors and the Commission representatives, Souvanna Phouma himself went to Sam Neua for discussions with Souphanouvong. Both leaders agreed to endorse the Phoumi-Sisoumang accords and to hold tripartite summit talks with Phoumi Nosavan. Souphanouvong said all four NLH Ministers and Secretaries of State would join the coalition in the neutralized Luang Prabang. ${ }^{34}$ Only at the end of March, 1964, did the three Laotian groups agree on the meticulous details of security measures to be taken for the forthcoming tripartite negotiations.

Although Souvana Phouma obtained Khrushchev's personal assurances, he no doubt realized that the tripartite negotiations could hardly succeed without Chinese and North Vietnamese support, especially in view of their growing influence over the NLH leaders. This consideration inspired Souvanna Phouma's "good-will” visit to Peking and Hanoi in April, 1964. For China, however, it seemed clear that Souvanna Phouma had lost much of his previous usefulness relative to Chinese objectives in Laos and had shown overt anti-Communist inclinations since April, 1963. If, however, he could be persuaded to resume a stance conducive to their interests, the Chinese might again attempt to 
exploit his premiership. Given this prospect, the Chinese had prudently refrained from attacking Souvanna Phouma in person, thus keeping the door open for a reconciliation with him. For this reason, even when the NLH bitterly accused Souvanna Phouma of opportunistic behavior, the Chinese had publicly contended that he had only bowed to American "coercion."

As a result Souvanna Phouma's visit to China in 1964 took place in circumstances vastly different from those of his previous official visits. This time the Chinese received him with a mixture of suspicion and expectation and without the enthusiastic fanfare that had been accorded him in the past. At a Peking banquet Chou En-lai, mindful of the visitor's recent pro-American tendency, emphasized the "common wishes and interests" between China and Laos in fighting imperialism and safeguarding peace in Indo-China. ${ }^{35} \mathrm{He}$ charged the U.S. "imperialists" with violating the Geneva agreements and creating all the trouble in Laos. It was essential for Chou that a peaceful settlement in Laos be achieved without external interference and with the cooperation of "patriotic forces." In the context of Laotian politics Chou meant to encourage a common front composed of Souphanouvong's NLH, Deuane's progressive neutralists, and Souvanna Phouma's conservative neutralists. But, in the Sino-Laotian joint statement, he voiced a hope that the "three political forces"-not only the "patriotic forces" but also the right-wing group-would join together and settle their own problems without foreign interference. ${ }^{36} \mathrm{He}$ also pledged Chinese support to Souvanna Phouma's government in "pursuing a policy of peace and neutrality," inferring that China might not support it if it did not follow such a policy. If Chou indeed meant this, his conditional support could have been just another manifestation of his doubts regarding Souvanna Phouma's political orientation. At any rate the Chinese gave the visitor a formal blessing for the tripartite negotiations.

It seems likely that the Chinese expressed to Souvanna Phouma their dissatisfaction over the understanding reached between Phoumi Nosavan and South Vietnamese Premier Nguyen Khanh in March, 1964, according to which Laos agreed to the reopening of Saigon's Embassy to Vientiane and permitted South Vietnamese soldiers to enter Laos in hot pursuit of the "Vietcong." Such a protest would account for Souvanna Phouma's declaration that he was pleased with the Chinese 
decision not to link the solution of Laotian problems with that of the conflict in South Vietnam. Earlier, on his way to China, Souvanna Phouma met with Premier Pham Van Dong in Hanoi, and their joint statement reaffirmed the principle of noninterference in the domestic affairs of each other. During Souvanna Phouma's stay in China, 227 delegates of the Neo Lao Haksat opened the second National Congress in Sam Neua province, elected the central leadership, and adopted a ten-point political manifesto. ${ }^{37}$ Although the manifesto continued to call for negotiations among three Laotian groups, it nevertheless emphasized the importance of fighting U.S. "imperialism" and defending the "liberated areas." In these revolutionary base areas the NLH had indeed consolidated its control. It had, for example, undertaken agrarian reforms, abolished various taxes, opened new primary schools, and introduced collective work systems into some villages.

Section Three: Reorientation of Chinese Policy in Laos

On April 17, 1964, Souvanna Phouma, with formal support from Peking and Hanoi, held negotiations with Souphanouvong and Phoumi Nosavan in the Plain of Jars but failed to bridge the conflicting positions of his two counterparts. Two days later any remaining hope for further tripartite talks was completely shattered by the right-wing generals' coup d'état in Vientiane. Generals Kouprasit Abhay and Siho Lamphoutacoul placed Souvanna Phouma under house arrest and declared their intention to reorganize his already paralyzed government without NLH Ministers. The coup was immediately confronted with repudiations not only by the Communist countries but also from the United States and Great Britain.

As the coup threatened to eliminate even a semblance of the coalition formula in Laos, the Chinese predictably responded with accusations and demands. They charged that the coup was a "premeditated action" jointly engineered by the United States and the right-wing generals in violation of the Geneva settlement. ${ }^{38}$ Though they said the coup's immediate objective was to prevent further tripartite summit talks, they viewed its significance in the broad context of U.S. policy throughout Indo-China. The coup, they insisted, was only one step in U.S. plans to "tighten its control over Laos, expand its war of aggression in South Vietnam, and aggravate the tension in Indo-China and Southeast Asia." 
In a propaganda offensive closely coordinated with the NLH and North Vietnam, the Chinese demanded the release of Souvanna Phouma and the punishment of the coup leaders. They also suggested that the three Laotian groups should meet and adopt measures to ensure that the coalition government could function. In spite of their deep suspicion toward Souvanna Phouma, the Chinese backed up his premiership hoping that he would form the united front with the NLH against the right-wing generals and repeat the earlier Souvanna Phouma-Souphanouvong alliance forged in the wake of Phoumi Nosavan's 1960 rebellion. At that time President Eisenhower's endorsement of Phoumi Nosavan's armed revolt had so antagonized Souvanna Phouma that the latter had established an alliance with the Pathet Lao.

But this time President Johnson denounced the coup d'état and sent to Vientiane Assistant Secretary of State William Bundy as a troubleshooter. Unlike Parsons in October, 1960, Bundy, together with Ambassador Leonard Unger, worked out a compromise between Souvanna Phouma and the right-wing generals: while Souvanna Phouma regained his political freedom, he agreed to reorganize the government with people recommended by the coup leaders. Furthermore, Souvanna Phouma, having announced the merger of right-wing and neutralist forces under his leadership, asked the Pathet Lao to put its troops under his control for the sake of national unity. $\mathrm{He}$ in fact met with his halfbrother Souphanouvong in Khang Khay but failed to produce any constructive result. In an obvious rebuttal to the Chinese contention that he illegally promised to reorganize the coalition under U.S. "coercion," Souvanna Phouma declared that his exercise of power as a leader of the combined right-wing-neutralist forces was "free" and "legal."

The Chinese, however, insisted that America's mediation between Souvanna Phouma and the right-wing generals was part of an attempt to absorb the neutralists and set up an openly pro-U.S. government in Vientiane. When the Pathet Lao forces, in cooperation with Col. Deuane's progressive neutralist dissidents, drove Kong Le's forces out of the strategically vital Plain of Jars in the middle of May, the Chinese promptly called the action self-defensive. Aware that only a drastic offensive would upset the cooperation between Souvanna Phouma and Kouprasit Abhay, the Chinese flatly refused the British request that they help restrain the Pathet Lao's military activities. ${ }^{39}$ The suc- 
cessful Pathet Lao forces, it was estimated, were assisted by more than one dozen battalions of North Vietnamese regulars whose main function was to protect the supply trails through Laos; in addition each Pathet Lao unit contained a group of North Vietnamese cadres-estimated to number one for every ten Pathet Lao soldiers-who trained troops, conducted political indoctrination, and handled certain technical work. ${ }^{40}$ At the urgent request of Souvanna Phouma the United States increased its military and personnel assistance to Vientiane, and announced the dispatch of jet planes over the Plain of Jars. Souvanna Phouma also asked for military aid from Moscow in his letter to Soviet Ambassador Afanasyev; in refusing the request, the Soviet Government appealed for the resumption of negotiations among the three Laotian groups. ${ }^{41}$

In the controversy over foreign military interference in Laos the Chinese found themselves directly involved. When the Laotian Ministry of National Defense charged in May, 1964, that two Chinese battalions had long been in Muong Sing and that two additional companies had fought the Royal Army in Long Ya, the Chinese denied the "slanders" through the Hsinhua News Agency, just as they had denied a similar allegation a year earlier. ${ }^{42}$ After declaring that "Chinese troops have never entered any place in Laos," the Hsinhua statement said those fabricated allegations were meant to confuse international public opinion and to cover up U.S. military maneuvers. In response to proposals by Prince Sihanouk and by President Charles de Gaulle for another Geneva Conference, Chen Yi suggested on May 26 that it was "urgent" and "imperative" for the Co-chairmen to reconvene, without any preconditions, a fourteen-nation conference at Phnom Penh in June, 1964. ${ }^{43} \mathrm{He}$ also asked them to instruct the three Laotian groups to send a single Laotian delegation to the proposed Phnom Penh parley. Had that conference ever been held, he would, we can assume, have proposed discussion of such region-wide issues as Cambodia and South Vietnam.

Souvanna Phouma, however, refused to accept the call for an unconditional conference outright. Although he acknowledged the need for a conference, he presented two preconditions-a cease-fire and the withdrawal of Pathet Lao forces to their positions of mid-May, 1964. His stand, unacceptable to the Pathet Lao, strengthened U.S. opposition to any conference on Laos; a State Department statement simply indi- 
cated that a conference should be held only if Souvanna Phouma's conditions were met. $^{44}$

To gain a diplomatic objective, the Chinese exploited an incident during June, 1964, involving an attack by alleged U.S. fighter-bombers on the Chinese Economic and Cultural Mission in Khang Khay, which killed one Chinese and wounded five others. They bitterly denounced this "new debt of blood" the United States owed China, but held back from making it a casus belli. Neither did they offer any specific threat of retaliation in case of a second provocation by the United States. Rather, they used the incident to promote their diplomatic interest. Since the bombing episode made the Laotian situation all the more critical, they argued, the Geneva Co-chairmen should immediately hold "emergency discussions" and call the fourteen-nation conference without further delay. ${ }^{45}$

But the United States dismissed the Chinese protest and continued to reject any new international conference on Laos. Secretary of State Dean Rusk simply suggested: "No new agreements are required. All that is needed is compliance with the agreements already made." ${ }^{\prime 6}$ Declaring that a Communist takeover in Laos would be as unacceptable as one in South Vietnam, he emphasized the broad stakes involved in the question of Laos:

It is in the vital interest of the free world that Peiping and Hanoi-and all Communists everywhere-learn, once and for all, that they cannot reap rewards from militancy, aggression by seepage, and duplicity. For our part, we certainly do not intend to abandon the peoples of Laos or Vietnam or other countries who are trying to remain free from Communist domination.

This statement clearly shows that Washington was just as ready to defend Laos and South Vietnam as Peking and Hanoi were to prove the invincibility of "people's war" in these same countries.

In the meantime the Chinese, stubbornly reiterating their own diplomatic preference, rejected all other alternatives for peaceful solution of the Laotian crisis. They were especially opposed to the British proposal for fourteen-nation ambassadorial consultations at Vientiane. They thought this merely a scheme to obstruct the proposed Phnom Penh conference. When the month-long consultations among only six countries-America, Britain, India, Canada, South Vietnam, and Thailand-adopted a final communique upholding Souvanna Phouma's 
preconditions for the conference and deploring North Vietnam's intervention into Laos, the Chinese simply called it "null and void." They argued that the Geneva accords did not authorize any meeting short of all fourteen nations. ${ }^{47}$

By the same legal argument the Chinese also opposed the Moscowendorsed Polish proposal for a meeting of six countries-the Co-chairmen (Britain and Russia), the Commission member-states (India, Canada, Poland), and Laos. The special importance accorded these five countries angered the Chinese, with their self-assumed responsibility for solving Asian problems. Thus, they attacked the Russian support for such an arrangement on the ground that any consultation among part of the Geneva Conference participants-even including the Cochairmen-would violate the provision for joint consultations and serve the U.S. policy of delaying an international parley. When the Soviet Union, faced with growing criticism of both Peking and Hanoi, scrapped the Polish proposal, the Chinese praised the change in Moscow's position. ${ }^{48}$

Despite occasional reconciliations the conflict between Peking and Moscow in world affairs grew worse, inevitably affecting their policies toward Laos. The Soviet Union often hesitated to take a peaceful initiative for fear of Chinese accusations. Sometimes even Moscow's silence was criticized. For example, People's Daily complained on June 15: "Will you [the Geneva Co-chairmen] ignore, connive with and even encourage the aggressive actions of U.S. imperialism or immediately adopt effective measures to stop them?" As Co-chairman, the Soviet Government was then advised not to remain silent in the face of such U.S. activities but to discharge its international duties "seriously and correctly." ${ }^{49}$

In the middle of 1964, however, Premier Khrushchev indicated his intention to retreat from an active role in Southeast Asia, even to the point of considering resignation from Geneva Co-chairmanship. $\mathrm{He}$ had to play the delicate game of preserving a general understanding with the United States in Laos while avoiding at the same time Chinese accusations of a "sell-out." The Soviet Union indeed complained that the Polish proposal for negotiations had been rejected under "various unfounded pretexts" (presumably including one raised by Peking), and that the systematic violations of the Geneva accords by "certain states" 
had placed the Co-chairmen in an awkward and fictitious position serving no useful purpose. ${ }^{50}$ If the international conference was not soon held, the Soviet Government threatened that it would be compelled to review the question of its continuing as a Co-chairman. When Khrushchev met with British Foreign Secretary R. A. Butler in July, he explained that the Soviet Union did not want deep involvement in Laos only to come into conflict with China. ${ }^{51}$

But the Chinese seemed to enjoy this very awkward position of the Soviet Union. For they saw in Moscow's powerless Co-chairmanship a convenient instrument of pressure and propaganda. Moreover the resignation of a Co-chairman was likely to render the Geneva system more chaotic and to undermine Peking's efforts for another conference. Thus, the Chinese persuaded Moscow not to relinquish its obligations as Co-chairman but to fulfill them more seriously. They made it clear, though, that should Moscow still wish to resign the Co-chairmanship, it was essential to hold a new conference first to discuss that question. ${ }^{52}$ After Khrushchev was overthrown in October, 1964, the new Soviet leaders-Party Chairman Leonid Brezhnev and Premier Aleksei Kosygin-gradually renewed their initiatives in Southeast Asia and never again raised the question of resigning from the Co-chairmanship.

Until April, 1964, China alternated between suspicion and optimism in its attitude toward Premier Souvanna Phouma. From April to June, however, relations between him and China deteriorated to an exchange of hostilities. The Chinese had long expected Souvanna Phouma to follow Sihanouk's policy, but to their disillusionment, he turned out to be the Nehru of Laos. From the Chinese perspective Souvanna Phouma, formerly a close friend and patriotic neutralist, turned anti-Chinese and rendered himself the tool of U.S. imperialism, opposing the patriotic forces in Laos. This public dispute with Souvanna Phouma was diplomatically costly to the Chinese, but they could hardly avoid repudiating his increasingly anti-Communist activities, which ranged from the merger of neutralist-right-wing forces to the unilateral reorganization of the coalition structure and the acceptance of U.S. military commitments. ${ }^{53}$

The dispute further intensified when Souvanna Phouma directly challenged the fundamental premises of Chinese policy toward Laos. Not only did he question the legal basis of the Chinese Economic and 
Cultural Mission in Khang Khay, but he also claimed that China had always followed a "policy of annexation" toward Laos. As evidence for this assertion he said that China was building a second road linking Yunnan and northern Laos; he also said that Laos had recently arrested two Chinese intruders in the northern part of the Kingdom. In response the Chinese categorically stated that they had not started building another road in Laos since they completed in April, 1963, the "Laotian-Chinese Friendship Highway," linking Phong Saly to Meng La in Yunnan Province. ${ }^{54}$ The two arrested Chinese "construction workers," they suggested, had merely crossed the border illegally; their case could be properly handled according to international practice.

The Chinese also retorted that the Mission had been legally established at the request of Premier Souvanna Phouma himself in 1961. Therefore, they said, "his lack of good faith" was "absurd and incredible." Since November, 1961, the Mission had been a useful instrument of Chinese policy in dealing with the NLH in Khang Khay area. In addition to its cultural and economic functions the Mission had controlled and coordinated a group of Chinese advisers and cadres attached to the NLH and thus, together with the Chinese Consulate-General in Phong Saly, facilitated Chinese activities in the "liberated areas," where the Russians had neither an official nor an unofficial representation. This is the reason that the Chinese, notwithstanding the heated controversy with the RLG, continued to preserve the Mission.

This controversy suggested that Souvanna Phouma's conservative nationalism conflicted sharply with China's Communist ideology and national interest. Obviously the Chinese could not leave untouched the implications of Souvanna Phouma's "vilifications" against their national pride and policy objectives in Laos. In an unmistakable warning, they declared:

Nothing good will come to Prince Souvanna Phouma if he chooses to follow in the footsteps of U.S. imperialism and the Laotian right-wing faction, opposing the patriotic forces at home and China and Vietnam Democratic Republic abroad. He should know that U.S. imperialism is playing a malicious trick to make him burn all his bridges behind him, estrange him from all forces which had once supported him and drive him into a blind alley. ${ }^{55}$

In order not to close the door completely on reconciliation, however, the Chinese presented three conditions whereby Souvanna Phouma 
might escape from that "blind alley": first, to renew unity with the $\mathrm{NLH}$; second, to deal with the right wing only on the basis of patriotism; and third, to follow a strict foreign policy of peace and neutrality entailing the resumption of his cooperation with Peking.

If he failed to fulfill these requirements, China repeated, the "genuine" middle forces in Laos would discard him. ${ }^{56}$ The Chinese argued that the middle forces, born and nurtured in the course of the patriotic anti-imperialist struggles in Laos, had already coalesced into an objective social force. This analysis meant that Souvanna Phouma could lead the country only by conforming to this unalterable social force; if he refused, he would lose his authority. In the past the Chinese had accepted Souvanna Phouma's leadership of the middle forces out of political expediency; but, as soon as he deviated from their expectations, they introduced a convenient sophistry about middle forces to question his leadership. In a discussion of the dual nature of middle forces in Chinese revolutionary experience, $\mathrm{Li}$ Wei-han concluded that, as the revolution progressed, a certain middle force, by losing a positive revolutionary aspect and assuming a negative reactionary aspect, lost its qualifications for leading the revolution and often became friends of the enemy. ${ }^{57}$ No doubt the Chinese found this process of political degeneration in Souvanna Phouma's recent "reactionary" and "hostile" inclinations.

Already neutralized by Souvanna Phouma's obstructive tactics, Chinese efforts to convene an unconditional conference on Laos were dealt a severe blow by the Gulf of Tonkin crisis in August, 1964. When North Vietnamese torpedo boats allegedly attacked two U.S. naval vessels in the Gulf of Tonkin, the U.S. immediately responded with air attacks against gunboats and certain supporting facilities in North Vietnam. Both President Johnson and Secretary Rusk argued that the North Vietnamese attacks were not an isolated event but part of a Communist drive to conquer South Vietnam and Laos and eventually dominate other free nations in Southeast Asia. "In Laos," the President added, "the North Vietnamese regime had maintained military forces, used Laotian territory for infiltration into South Vietnam, and most recently carried out combat operations." ${ }^{\text {"s }}$ Although President Johnson said the United States did not seek a wider war, the U.S. air attacks in 
North Vietnam could only lead to extended war efforts in subsequent years.

During the crisis the Chinese claimed that some of the U.S. airplanes attacking North Vietnam took off from Laotian bases, that the Pathet Lao's "liberated areas" became a frequent target of U.S. bombing missions, and that there was increasing military cooperation between Phoumi Nosavan and South Vietnam. In their usual region-wide assessment of the crisis they asserted that U.S. policy aimed to escalate armed aggression throughout Indo-China and to reverse its losing course in the Vietnam war. Faced with what they called America's new military blackmail in Indo-China, the Chinese apparently decided that their previous efforts for negotiations in Laos should give way to a campaign for a determined anti-U.S. struggle by the Indochinese people. For it seemed to them that a continuing insistence on negotiations under these tense circumstances might undermine the fighting will of the Pathet Lao and the National Liberation Front of South Vietnam. ${ }^{59}$

Indeed the historical "lesson" which the Chinese derived from the Tonkin incident showed the correctness of their extreme ideological position against imperialism and modern revisionism and deemphasized the usefulness of negotiations in Indo-China. On the basis of the Tonkin experience they could confidently reiterate their favorite polemical thesis that "one must not harbor illusions about imperialism" and "relaxation of vigilance and abandonment of struggle will forfeit world peace." ${ }^{\text {"0 }}$ Given such an ideological approach toward U.S. military maneuvers in Indo-China, it seems most probable that when Chen Yi conferred with Souphanouvong and Phoumi Vonvichit in Peking on August 22, he gave them China's doctrinaire interpretation of the Tonkin crisis and advised them not to show any sign of weakness at the forthcoming summit talks of the three Laotian groups in Paris.

At the tripartite meetings in September, Souphanouvong rejected Souvanna Phouma's proposals for neutralizing the Plain of Jars, occupied at the time by the Pathet Lao, and for recognizing the reorganized Vientiane government. When Souphanouvong returned to Peking to attend the fifteenth anniversary of the CPR, he said that the failure of the Paris talks was as much a result of obstructionism by Phoumi Nosavan as of Souvanna Phouma's capitulation to U.S. policy. ${ }^{61} \mathrm{He}$ still favored in principle a negotiated settlement in Laos, but his militant 
determination was also evident. If the United States and its "vassals" continued to attack the Pathet Lao, he warned, he would be obliged to strike back, just as Peking was urging. The U.S. aggression in IndoChina, he emphasized at Peking, required close cooperation among China, Laos, Cambodia, and North Vietnam as "four fraternal and neighboring countries." Significantly, he mentioned no role for the Soviet Union in this joint anti-U.S. struggle.

We should note here the similarity of his policy to Peking's, and also the correspondence between the NLH's strategic outlook and Peking's policy shifts in 1964. Apparently the Chinese ideological campaign against Soviet "revisionism" did increase the likelihood of Peking's emerging from this ideological dispute as the champion of the NLH's anti-U.S. struggle. Peking's militant ideological position against the United States "aggression" in Asia was more attractive and meaningful to the NLH leaders, who also faced in the United States a formidable arch-enemy. This common problem evidently led the NLH leaders to accept Peking's basic position and, with it, Peking's analysis of Laos' domestic and external problems. For example, Souphanouvong, like the Chinese, proclaimed that imperialism was unchanging and that opportunistic and revisionist illusions about U.S. imperialism were out of place. He also said that Johnson's accession to the Presidency did not alter the "aggressive and bellicose" nature of U.S. "imperialism." ${ }^{2}$ In ideological arguments with Moscow the Chinese often accused the Soviet "modern revisionists" of preaching that the Johnson Administration was sensible and realistic.

Outside the area of ideology and propaganda the Chinese supported the NLH's revolutionary movements with growing economic and military assistance. Without such Chinese aid and North Vietnam's massive military and economic commitments, the NLH could not have felt secure in fighting for survival against the U.S. power in Southeast Asia. As the U.S. military buildup increased in South Vietnam and Thailand, the NLH tended to identify itself with China even more closely than before. In the wake of the Tonkin incident and Moscow's indecisive position over the crisis, Souphanouvong probably felt it more urgent than ever to declare his appreciation for China's guidance and protection in his anti-U.S. crusade.

He stated at Peking that the Chinese revolutionary experiences and 
successes afforded the Laotian people an "extremely important lesson," a "good example of organization," and "correct and clear-sighted guidance." 63 He had never given such a public tribute to Moscow, and his admiration for the Chinese suggested his willingness to apply Mao's revolutionary experiences to the NLH's anti-U.S. struggle. In turn the Chinese praised the NLH's revolutionary leadership in Laos and bitterly criticized Premier Souvanna Phouma. This contrasted sharply with Moscow's apparent efforts to maintain a cooperative relationship with Souvanna Phouma and to close the widening gap between him and the NLH. This ambiguous and conciliatory approach tended to drive the NLH leaders further into Peking's embrace.

With their first nuclear detonation in October, the Chinese obviously expected to increase their influence upon national liberation movements. In a post-detonation statement they emphasized that their mastering of nuclear power would be a "great encouragement" to the revolutionary peoples and a "great contribution" to the cause of defending world peace. ${ }^{64}$ Such calculations elicited a favorable reaction from the NLH leaders, who, unlike the Russians, enthusiastically welcomed the Chinese test. In his message to Premier Chou En-lai, Souphanouvong praised the "tremendous contribution" which China's nuclear power could make to the Laotian people's anti-imperialist struggles. As close neighbors of China, he said, "Laotian people regard the success of the Chinese people as our own and rejoice at and are inspired by the important success of the Chinese people."65 More important, Nouhak Phoumsavan, an influential member of the NLH Central Committee, noted that the Chinese achievement dealt U.S. "imperialists" and other "reactionaries" a heavy blow and brought the policy of nuclear monopoly and blackmail into complete discredit. ${ }^{66}$

Despite the test, the CPR was far from attaining actual nuclear capability, let alone rivaling America's nuclear power. Yet the test did demonstrate China's military potentialities and enhance the attractiveness of its revolutionary model for the Pathet Lao. As a result the Chinese helped their image as leaders of national liberation movements, and encouraged the Pathet Lao's political and military activities.

When the United States stepped up its military pressure both in Vietnam and in Laos during the dry season of 1964, the Chinese saw in the move a coordinated effort against all revolutionary movements in 
Southeast Asia. As the U.S. "special war" in South Vietnam was faltering, they argued, President Johnson hoped to salvage something by spreading the war into Laos. Around this time the Chinese became increasingly conscious of "evidences" that the United States was extending the Vietnam war into Laos. First, William H. Sullivan, a "right-hand man" of Ambassador Maxwell D. Taylor, was named Ambassador to Laos. Again President Johnson accused North Vietnam of both stationing and sending troops through Laos. Finally, the U.S. intensified its air attacks over the "liberated areas" of Laos and South Vietnam, and called for Phoumi Nosavan's military cooperation with South Vietnam.

In the face of these and other "evidences" the Chinese issued repeated warnings against the United States. An "observer" in People's Daily (December 12, 1964), for example, asserted that the "liberated areas," the precious fruits of the Laotian people's struggles, should be protected from U.S. aggression and added that "those who play with fire will burn themselves." At the first session of the third National People's Congress, Chou En-lai declared that if the United States enlarged the Vietnam war, the Chinese People's Republic would "absolutely not sit idly by." 67

On the military front the Pathet Lao operations were effectively restrained by continued U.S. bombing and strafing, especially from January, 1965. It was reported at the time that the Chinese had equipped the Pathet Lao with their $37 \mathrm{~mm}$ anti-aircraft guns to resist U.S. air operations. ${ }^{68}$ When the Pathet Lao shot down two U.S. jets in midJanuary, the United States publicly sought to justify the air attack as a required response to the repeated Communist violations of the 1962 accords. The Chinese immediately asked Moscow and London to take realistic actions against the new military adventure of the U.S. in Laos, but did not repeat the need of a conference on Laos. ${ }^{69}$ When the National Liberation Front destroyed U.S. military installations in the Pleiku area in early February, the U.S. not only started retaliatory attacks against the southern portion of North Vietnam but also intensified bombing missions against the "Ho Chi Minh" routes through Laos.

In response to the accelerating American military challenge in IndoChina, the Chinese firmly endorsed the formation and mobilization of an anti-U.S. united front among the Indochinese peoples and identified themselves with the cause of such "popular movements." After taking 
part in the "International Conference for Solidarity with the People of Vietnam against U.S. Imperialist Aggression and for the Defense of Peace," held in Hanoi in November, 1964, the Chinese attached a greater political significance to the "Indochinese People's Conference" at Phnom Penh in February, 1965. ${ }^{70}$

In a message of inspiration to the Presidium of the Phnom Penh Conference, Chou En-lai asserted that the United States, in gross violation of the 1954 and 1962 Geneva agreements, had conducted a "war of aggression" in South Vietnam, "direct armed intervention" against Laos, and "political subversion" against Cambodia. ${ }^{71} \mathrm{He}$ said that, without withdrawal of U.S. aggressors from this entire region, any international agreement on Indo-China would, like the 1954 and 1962 agreements, be sabotaged; therefore, Chou emphasized, as an essential condition for any peaceful solution, the United States should withdraw its military forces from Indo-China "completely, immediately and unconditionally." This important policy statement meant that the Chinese in 1965 were not interested in any partial solution without unconditional withdrawal of U.S. forces from all parts of Indo-China. The Chinese would not turn back the clock to 1962, when they had agreed to a settlement on Laos which did not require withdrawal of U.S. troops from South Vietnam.

In a resolution on Laos the Conference, while demanding that the U.S. withdraw its military personnel from that country, proposed a new Geneva Conference without any prior conditions. Just as they were indifferent to a similar suggestion in February, the Chinese conspicuously failed to endorse that proposal in their otherwise enthusiastic reaction to the Phnom Penh Conference. In his message to Prince Sihanouk and the Permanent Secretariat, Chou En-lai pledged that 650 million Chinese people would not spare any effort in assisting the Indochinese people's anti-U.S. struggle until final victory. But North Vietnam was dissatisfied with the participation of South Vietnam's "bourgeois neutralists" and the establishment of the Permanent Secretariat at the Conference. ${ }^{72}$

Chou's pledge was soon spelled out in greater detail in Chen Yi's letter to North Vietnamese Foreign Minister Xuan Thuy. On March 28, Chen promised to send the necessary material aid and even Chinese volunteers to the South Vietnamese people at the latter's request. This 
was a response to an appeal issued a week earlier by the National Liberation Front of South Vietnam, which declared that it might request soldiers from various countries for South Vietnam if the United States continued to commit its combat troops to South Vietnam and to extend the war to North Vietnam and Laos. ${ }^{73}$ The CPR had never made such a firm, though conditional, public commitment to the Pathet Lao's revolutionary cause. Yet the likelihood remained that it would not hesitate to make a similar pledge if that step was considered conducive to its own interests. In April, the CPR also supported the National Liberation Front and the Democratic Republic of Vietnam when they responded to President Johnson's proposal for "unconditional discussions" on Vietnam by demanding the withdrawal of U.S. forces from South Vietnam as a precondition for such discussions. ${ }^{74}$ The CPR seemed to adopt a similarly rigid position on the question of reconvening an international parley on Laos.

Although the International Commission proved to be ineffective against these violent developments in Laos, it still remained a persistent target of Chinese attack. The Geneva accords stipulated that the Cochairmen should make appropriate recommendations concerning the Commission's termination not later than three years from July, 1962. When the NLH Central Committee asked the Co-chairmen in July, 1965, to consider the Commission's status, the Chinese called the request "timely" and also asked the Co-chairmen to deliberate on the question of suspending the Commission's activities. ${ }^{75}$ In December, however, the British Government unilaterally published a 200-page report submitted by the Indian and Canadian delegations of the Commission in September, 1965. On the basis of an interrogation of three North Vietnamese prisoners captured in Laos, these delegations had concluded that "regulars of the North Vietnamese Armed Forces" had entered Laos between February and September, 1964, in groups varying in size from 50 to 650 soldiers and had fought, along with the Pathet Lao troops, against the Royal Laotian Army. ${ }^{76}$ After warning the United States against using the report as a pretext to spread the war to Laos, the Chinese asked the British Government and the Indian and Canadian members of the Commission to cease all their "illegal activities" immediately.

Meanwhile, the Chinese made every effort to undermine the author- 
ity of the Vientiane government, nominally headed by Premier Souvanna Phouma but actually controlled by the right-wing generals. After Generals Phoumi Nosavan and Siho Lamphoutacoul escaped into Thailand following an abortive coup d'état in early February, 1965, Gen. Kouprasit Abhay, along with Generals Ouan Rathikoun and Oudone Sananikone, emerged as a new strong man in Vientiane. Instead of Prince Boun Oum (the United States favorite), Education Minister Leuam Insisiengmay assumed the Vice-Premiership vacated by Phoumi Nosavan. Such right-wing leaders as Phoui Sananikone, Sisouk Na Champassak, Leuam Insisiengmay, and Kouprasit Abhay strengthened their political foundations in July, through restricting the general election for the National Assembly; some 25,000 civil servants, army officers, teachers, merchants, and policemen voted to elect 59 deputies out of 192 candidates. Neither the NLH nor the Santiphab were allowed to participate in the elections. ${ }^{77}$ In September, Premier Souvanna Phouma reorganized the cabinet; while keeping four Pathet Lao posts intact, he appointed Prince Boun Oum as Minister of Religion and Sisouk Na Champassak as Minister of Finance in place of Phoumi Nosavan. The schism within the right-wing groups, coupled with the fatal split of the neutralist group, made the Laotian political scene all the more confused and unpredictable. And the gap between the RLG and the NLH continued to widen as the latter, together with Hanoi and Peking, consistently repudiated Leuam Insisiengmay's Vice-Premiership, restricted elections, and Souvanna Phouma's cabinet reshuffle.

The Chinese welcomed and encouraged as correct revolutionary tactics a series of measures taken by the NLH to mobilize the united front movements in Laos. In order to identify and publicize themselves more fully, the Pathet Lao forces adopted a Chinese type of official name, "the Laotian People's Liberation Army," under Supreme Commander Khamtay Siphandone (a member of the Standing Committee of the NLH Central Committee). The NLH sponsored its first mass movement for self-reliance and productivity, and held a conference of administrative representatives of the "liberated areas." Most significant was the first meeting of the Political Consultative Conference at Sam Neua in October, 1965, between the NLH and the progressive neutralist forces. The Conference issued the so-called "Four-Point Stand and Five-Point Solution," a major policy statement repeated throughout 
1966 and $1967 .{ }^{78}$ The manifesto emphasized as an immediate task that the political and military power of patriotic forces be increased and the liberated areas transformed into strong bases for a "protracted war of resistance." Like the statement the National Liberation Front of South Vietnam made in March, 1965, the Laotian manifesto "reserved" the right to call for, if necessary, the "practical support in all aspects" of the people and governments of peace-loving countries.

In response the Chinese praised the manifesto as an expression of the broad anti-U.S. united front and of the common will of the Laotian people. A spokesman for the Chinese People's Political Consultative Conference (CPPCC) expressed China's "firm support" for the manifesto. Similar expressions of support and sympathy were echoed in a number of statements by China's various "people's organizations." Yet the Chinese clearly refrained from making the same kind of public pledge on behalf of the Laotian manifesto as that which Chen Yi had issued in response to the National Liberation Front of South Vietnam in March. The difference was not sufficient, however, to suggest that the Chinese considered the revolutionary movement in Laos less important than that in South Vietnam. As the military situation in South Vietnam turned against the National Liberation Front in the winter of 1965, the Chinese modified their earlier optimistic outlook and concomitant public pledge, and assumed a more flexible commitment which allowed them more freedom of diplomatic maneuver in the fluid situation of Southeast Asia. ${ }^{80}$

Section Four: Laos, The Vietnam War, and The Chinese Cultural Revolution

During the winter of 1965, and thereafter, the Vietnam war was rapidly escalating in violence level and in geographic scope, and consequently spreading into Laos. The main military dimensions of Laos' conflict were directly relevant to the use of the "Ho Chi Minh trails." In an attempt to secure these complex jungle trails, guarantee the increasing infiltration of military personnel and supplies into South Vietnam, and assist the Pathet Lao's military operations, North Vietnam strengthened its regular army troops in Laos to the 20,000-30,000 level at the end of $1965 . .^{81}$ According to Douglas Pike, even the actual headquarters of the National Liberation Front of South Vietnam was be- 
lieved to be in the Attopeu area of Laos. ${ }^{82}$ The U.S. used its B-52 strategic bombers against these trails and authorized its forces in South Vietnam to enter Laos in hot pursuit of enemy troops. It also stepped up its military aid to the Royal Laotian Army troops and assumed a direct advisory role over them.

While the Chinese were providing North Vietnam with a substantial amount of military and economic assistance and more than 40,000 noncombatant advisers and engineers, they were deeply concerned that the war in Vietnam might spill even further into Laos. ${ }^{83}$ They repeatedly warned that the U.S. was planning to dispatch its ground forces to Central and Lower Laos and build a strategic bridgehead linking Thailand and South Vietnam. In a Foreign Ministry statement on January 18, 1966, the Chinese condemned the rapid increase in the U.S. military build-up and bombing missions in Laos. On the following day Defense Minister Lin Piao sent a special message to Supreme Commander Khamtay Siphandone of the Laotian People's Liberation Army, praising its heroic fighting in the forefront against the United States. In order to counter the expected massive U.S. invasion into Laos, Lin Piao promised the "firm support" of the Chinese people and the Chinese People's Liberation Army. ${ }^{84}$

We must note that the timing of these two Chinese statements against U.S. policy in Laos coincided with a temporary suspension of U.S. bombing over North Vietnam from December 24, 1965, to January 31, 1966. During this time President Johnson conducted a worldwide diplomatic campaign to bring North Vietnam to peace talks, and Secretary Aleksandr Shelepin of the Soviet Communist Party led a top-level delegation to Hanoi. Fearing that the new Soviet leaders had inherited Khrushchev's weakness toward imperialism, the Chinese apparently suspected Shelepin of leading a peace mission ready to make a "deal" with the United States over Vietnam. To dispel any wishful thinking on Moscow's or Hanoi's part, the Chinese clearly stated: "A mere glance at the doings of United States imperialism in Laos and the whole of Indo-China will reveal the real aims of the Johnson Administration in its 'peace offensive' on the Vietnam question." 85

To intensify the moral condemnation against U.S. bombing raids in Laos, China's means of communication were extensively mobilized to protest the alleged use of toxic chemicals by the United States. In 
a letter to the Geneva Co-chairmen in February, Phoumi Vongvichit claimed that the U.S. bombers were dropping napalm, phosphorous bombs, and toxic chemicals to massacre the Laotian people, and that the raids had been carried out on an increasingly larger scale-formations of 15 to 20 aircraft conducting from two to three hundred raids a day. ${ }^{86}$ The Chinese directly involved themselves by charging that U.S. jet planes had attacked and damaged their Consulate-General at Phong Saly and their Economic and Cultural Mission at Khang Khay in Feb. ruary and March, 1966. A strong protest was lodged against the United States in Chinese Foreign Ministry statements issued immediately after each alleged attack: ${ }^{87}$

In the course of expanding the war in Indo-China, U.S. imperialism has time and again made Chinese diplomatic missions in Laos targets of its attack. . . . This constitutes a deliberate provocation to the Chinese people. It is an account which must be settled. The Chinese Government strongly protests against this barbarous crime of the U.S. imperialists and their followers and solemnly points out that they must bear full responsibility for all the consequences arising therefrom.

They issued a more serious warning to the RLG authorities for allowing the U.S. planes to carry out such raids and for taking part in anti-Peking activities. This put direct psychological pressure upon Vientiane against its open cooperation with Washington in Indo-China. Whereas Souvanna Phouma questioned the legal basis for a Chinese Consulate-General at Phong Saly, both the NLH and the National Liberation Front of South Vietnam condemned the U.S. attack against the Chinese premises and expressed their solidarity and friendship with the "great, fraternal Chinese people."

While Souvanna Phouma's leadership was somewhat troubled by the usual rivalries among divergent factions in Vientiane, as evidenced by the National Assembly's rejection of the Government's budget request in September and Air Force General Thao Ma's rebellion against General Kouprasit Abhay in October, the "liberated areas" strengthened ties among themselves. ${ }^{88}$ In a series of joint statements issued during 1966, six NLH and progressive neutralist members of the 1962 National Union Government called upon the Laotian people, irrespective of political and religious beliefs, to unite around them for the final struggle against the United States. ${ }^{89}$ The second meeting of the Political Consultative Conference of the NLH and the patriotic neutralist forces, held 
in November, 1966, reaffirmed the correctness of the "Four-Point Stand and Five-Point Solution" adopted by the first meeting in October, 1965. It also decided to develop regular troops and guerrillas simultaneously, to promote the national patriotic movement in RLG-controlled areas, and to receive support from Indochinese and other Asian peoples. The $\mathrm{NLH}$ also organized the meetings for the youth and the intellectuals in the spring, held a cadre training institute in July, and sponsored the first meeting of administrative workers of Sam Neua in October.

These conferences and activities, which were held under the NLH's auspices, were ultimately controlled and supervised by a small political elite of the Laotian People's Party (LPP) - a probable adjunct of the former Indochinese Communist Party. In an unusual "fraternal party greeting" sent to the Japanese Communist Party in October, 1966, Secretary-General Kaysone Phoumvihan of the LPP Central Committee (NLH's Vice-Chairman) publicly admitted that "under the correct leadership of the Laotian People's Party, the Laotian people are solidly united in the Neo Lao Haksat and are encouraged by the unreserved support from various fraternal parties." ${ }^{\text {"90 }}$ It was the first time that the LPP revealed the name of its Secretary-General, its leadership over the $\mathrm{NLH}$, and its fraternal relationship with the Japanese Communist Party. Yet there is little information to show the LPP's internal organization, membership size, and exact functions in Laos. Souvanna Phouma once said that the Pathet Lao presided over by Souphanouvong was only a "show window" of the People's Party Central Committee, which was controlled by Hanoi and Peking. ${ }^{91}$

Of late Premier Souvanna Phouma had made extensive efforts to link the political and economic life of Vientiane with the free world, especially with pro-U.S. Asian countries. After Souvanna Phouma's official visit to Bangkok in November, 1965, Thai Prime Minister Thanom Kittikachorn, accompanied by Foreign Minister Thanat Khoman, paid his first state visit to Vientiane in March, 1966. The resulting Thai-Laotian joint statement emphasized the need for trade expansion, economic and technical cooperation, and electrical power exchange. ${ }^{92}$ Economic and other contacts between Vientiane and Saigon steadily grew after the reopening of the South Vietnamese Embassy to Laos in March, 1964: Laos, for example, even donated to South Vietnam 1 million kip $(\$ 4,167)$ for flood relief in February, 1965. Japan 
TABLE 6

National Budget of Laos: FY 1964-67a

(In Millions of Dollars)

\begin{tabular}{|c|c|c|c|c|}
\hline & FY1964 & FY1965 & FY1966 & FY1967 \\
\hline Revenues & $13.3^{\mathrm{c}}$ & 19.7 & 19.7 & 26.6 \\
\hline $\begin{array}{l}\text { Expenidtures } \\
\text { (1) Civil Budget ................... } \\
\text { (2) Military and }\end{array}$ & $\begin{array}{c}50.6 \\
(21.6)\end{array}$ & $\begin{array}{c}43.0 \\
(13.2)\end{array}$ & $\begin{array}{c}59.8 \\
(19.9)\end{array}$ & $\begin{array}{c}64.1 \\
(24.5)\end{array}$ \\
\hline Police Budget & $(29.0)$ & (29.8) & $(39.9)$ & (39.6) \\
\hline Total Deficits ......................... & 37.3 & $23.3^{\mathrm{a}}$ & 40.1 & 37.5 \\
\hline
\end{tabular}

${ }^{a}$ Source: Fact Sheet (Vientiane: USAID/Laos, 1967).

${ }^{b}$ Actual as of July 26, 1967.

' Includes $\$ 0.6$ from Laos Stabilization Fund.

${ }^{\mathrm{d}}$ Without consideration of $\$ 5.2$ from U.S. budget support.

spent $\$ 2.8$ million in aid to build power generators, a filter plant, and a water system in Laos. It also spent a few additional million dollars for industrial, mining, and other studies; for medical facilities, demonstration farms, and technical training; and for the 72-member Japanese "Peace Corps" volunteers in Laos. ${ }^{93}$ But the RLG had been deeply troubled by chronic economic problems-trade imbalance, heavy military and security expenses, and immense budget deficits.

In 1966 alone, Premier Souvanna Phouma met with U.S. Vice-President Humphrey at Vientiane, participated in the Ministerial Conference for Economic Development of Southeast Asia at Tokyo, paid state visits to the Soviet Union and France, and conferred with President Johnson in Washington. He sent a Lao observer to the meeting of the Asian and Pacific Council (ASPAC) in Seoul, expressed his willingness to establish diplomatic relations with South Korea and Malaysia, and pledged to the Asian Development Bank a contribution of $\$ 420,000 .^{94}$ During

\section{TABle 7}

Foreign Trade of Laos: $1963-66^{a}$

(In Millions of Dollars)

\begin{tabular}{|c|c|c|c|c|}
\hline & 1963 & 1964 & 1965 & $1966^{b}$ \\
\hline Imports $(A)^{c}$ & 29.0 & 25.5 & 32.9 & 20.6 \\
\hline 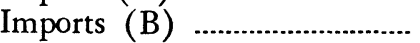 & 0.7 & 0.9 & 1.0 & 0.3 \\
\hline 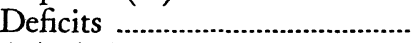 & 28.3 & 24.6 & 31.9 & 20.3 \\
\hline (B) $/(\mathrm{A}) \%$ & 2.4 & 3.5 & 3.0 & 1.4 \\
\hline
\end{tabular}

a Source: Fact Sheet (Vientiane: USAID/Laos, 1967).

'Through June 30, 1966.

${ }^{\mathrm{c}}$ Excluding gold, but including all foreign aid project commodities. 
1967, too, Souvanna Phouma carried on extensive diplomatic activities: he invited Australian Prime Minister Harold Holt to Laos in April, and Japanese Prime Minister Eisaku Sato in September; he conferred with Thai Prime Minister Thanom in April, spoke at the U.N. General Assembly in October, held discussions with President Johnson, and visited Australia in October. ${ }^{95}$

TABLE 8

U.S. Economic Assistance to Laos: FY1955-67a (In Millions of Dollars)

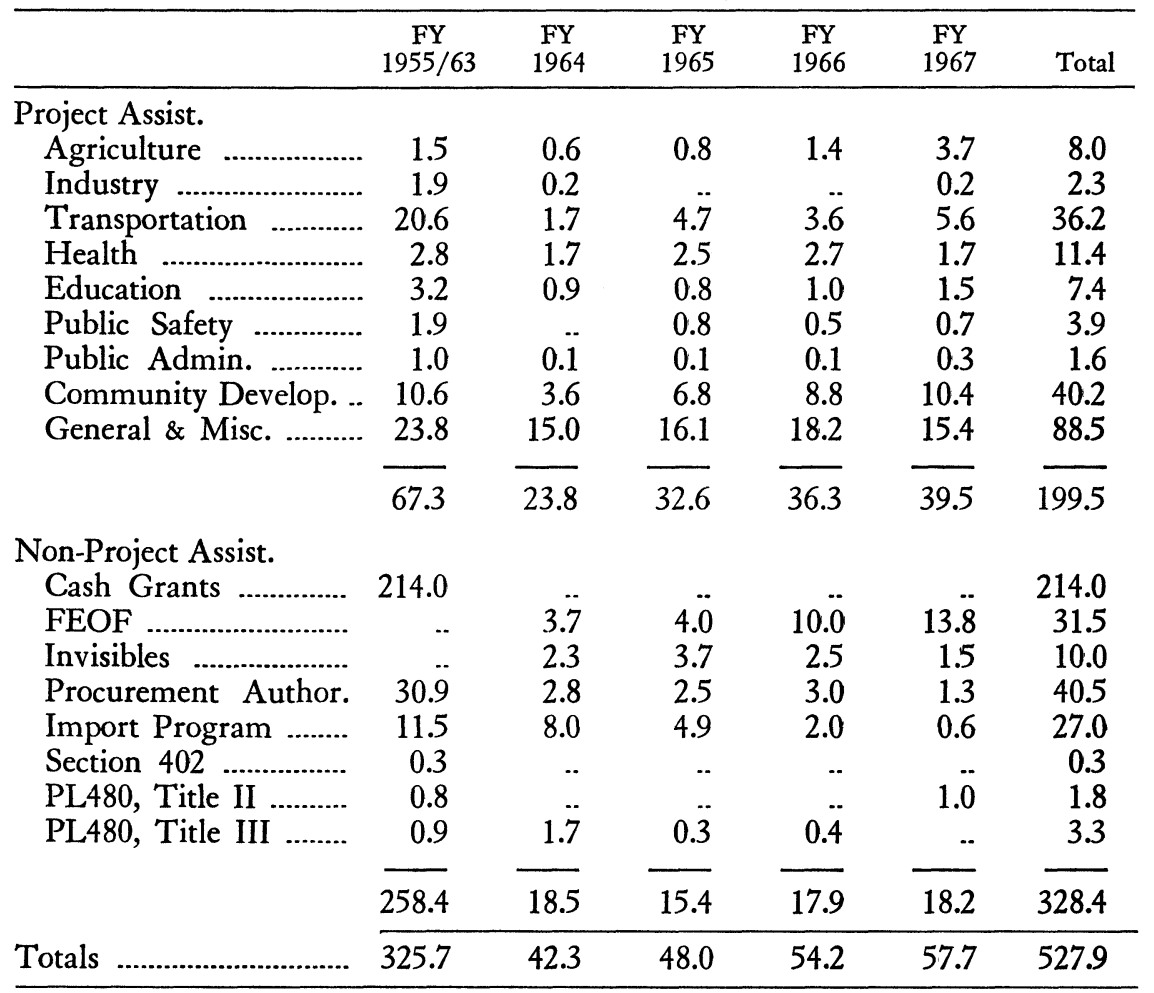

a Source: Fact Sheet (Vientiane: USAID/Laos, 1967).

Following a temporary slowdown in 1962-63, the United States had increased its economic assistance to Vientiane. Assistant Secretary of State William P. Bundy argued at the House Committee on Foreign Affairs in March, 1966, that "free world support continues to be essential to the [Laotian] Government's capacity to maintain itself against Communist military pressure." ${ }^{\text {"66 }}$ In fiscal year 1967, the U.S. 
gave $\$ 58$ million to Laos, excluding the classified military assistance believed to be higher than the economic aid. But it attempted to correct its earlier mistakes of overemphasizing military aid and of making its grants in cash payment. It launched such ambitious development projects in strategic rural areas as "cluster villages" and "forward areas"; as of July, 1967, the "cluster villages" were concentrated in 14 areas involving 1,483 villages and more than 380,000 people, and the "forward areas" in 9 areas involving 149 villages and 83,000 people. The U.S. also expanded the scope of its multilateral economic assistance programs, including the Commodity Import Program, the Foreign Exchange Operations Fund (FEOF), and the Nam Ngum Development as a part of the Mekong River Development Projects. $^{97}$

Compared with the extensive U.S. aid programs, China's economic assistance in Laos had been limited in size and area. The first aid project the Chinese officially undertook was the construction of a modern highway linking Meng La in Yunnan Province and the city of Phong Saly in northern Laos. When they completed the 50-mile long road, including bridges, houses for maintenance workers, and other installations, they named it the "Laotian-Chinese Friendship Highway" and handed it over to the RLG in May, 1963. The Chinese probably saw the project as yielding considerable political and strategic benefits for a small outlay of capital and time, especially because Phong Saly had been the Pathet Lao's revolutionary stronghold and the site of a Chinese Consulate-General.

The road construction was indicative of China's persistence in spreading its communications networks with Laos. The Chinese concluded a civil transport agreement in 1962, and a further agreement in 1963 on exchanging information between China's Hsinshua News Agency and the Laotian Ministry of Information, Publicity and Tourism. They delivered to Laos two teletype sets to receive the Hsinhua news dispatches and sent two Chinese technicians to show how the sets were to be operated. In the early post-Geneva period, the Chinese agreed to consider the RLG's request for extending the highway from Phong Saly to Nam Tha and to advance to Laos a long-term loan for construction of "certain industrial projects" and for "necessary technical assistance and equipment." 98 When relations between Vientiane and 
Peking deteriorated in subsequent years, these agreements could not be implemented. But the Chinese appeared to increase their economic and military assistance to the "liberated areas" through their Economic and Cultural Mission at Khang Khay and Consulate-General at Phong Saly. ${ }^{99}$

In an effort to strengthen their relations with the "liberated areas," the Chinese also used various methods of "people's diplomacy"-exchange of visits, cultural cooperation, and organizational relations. They had invited to China a number of political and cultural delegations, including journalists, artists, dancers, students, generals, Buddhist monks, Cabinet Ministers, and National Assemblymen. ${ }^{100}$ Yet the traffic in visits, both official and unofficial, remained one-way; the Chinese did not send their high-ranking visitors to Laos. Of course the danger to visiting Chinese in the "liberated areas," as well as the strained relations between Peking and Vientiane, was in part responsible for this. A recent exception was the visit of China's Yunnan Art Troupe to Xieng Khouang in 1966, and to Sam Neua in 1967, to perform in the "liberated areas."

Occupied more and more with the ever-growing war against the U.S. in recent years, North Vietnam tended to deemphasize the Pathet Lao's immediate revolutionary aspirations except where its own interest was directly involved. For example, North Vietnam could hardly strengthen the Pathet Lao's fighting capabilities; instead it often used the Pathet Lao troops as coolie labor along the "Ho Chi Minh trails" or as support forces in Vietnam operations. The coolie labor, food shortage, and military pressure evidently caused a steady rise in Pathet Lao deserters during 1966, and thus a decline in Pathet Lao forces from 30,000 in May, 1964, to 20,000 in June, 1966. ${ }^{101}$ When I interviewed Soth Phetrasi, a chief NLH representative to Vientiane, in October, 1967, he readily admitted the Pathet Lao's loss of "some grounds" during 1966, and attributed this solely to the intense U.S. bombing raids. But he was quick to add that the "liberated areas" still embraced more than threefifths of Laos with one-half of the total population; on the other hand, Souvanna Phouma said, "We control two-thirds of the territory and four-fifths of the population." 102 The Pathet Lao leaders appointed their own governors in at least nine out of sixteen Lao provinces, including Sam Neua (Houa Phan), Phong Saly, Nam Tha (Houa Khong), 
“Results” of Pathet Lao's Military Operations: 1966-67a

\begin{tabular}{|c|c|c|}
\hline & 1966 & 1967 \\
\hline \multicolumn{3}{|l|}{ Total Casualties of the } \\
\hline RLG Army Troops & 11,902 & 16,000 \\
\hline 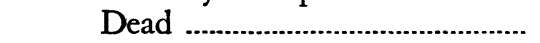 & $(6,325)$ & \\
\hline Wounded .............. & $(2,970)$ & \\
\hline Prisoners & $(2,607)$ & \\
\hline Airplanes Destroyed & 203 & 287 \\
\hline 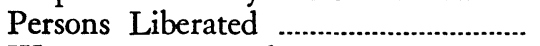 & 20,000 & $\ldots . .$. \\
\hline 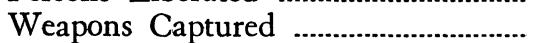 & 2,727 & $\ldots . . . b^{b}$ \\
\hline
\end{tabular}

a Sources: People's Daily (January 30, 1967) and Peking Review (April 12, 1968).

${ }^{b}$ No figures were given in these two categories for 1967.

Xieng Khouang, and Vientiane, and consolidated their political bases in the "liberated areas." In December, 1967, they held the first economic and financial conference of the "liberated areas" and even adopted a 3-year economic plan (1968-70). ${ }^{103}$

With North Vietnam absorbed in its own war efforts, the Chinese apparently assumed increasing responsibilities toward the Pathet Lao. It was believed that in 1966, they stepped up their military and economic aid to the Pathet Lao and sent to northern Laos more than 1,000 political advisers, anti-aircraft specialists, and logistical personnel. They were also in the process of extending the strategic highway in northern Laos. ${ }^{104}$ To boost the morale among the Pathet Lao forces, the Chinese promised all sorts of unreserved support, preached the "paper tiger" thesis of imperialism, and offered advice on revolutionary self-confidence. In a letter to Phoumi Vongvichit in August, 1966, for example, Chen Yi asserted: "All revolutionary people are sure to win final victory so long as they do not believe the 'nice words' of the imperialists and are not intimidated by their bluster, but dare to wage tit-for-tat struggles against them." ${ }^{105}$ In the process the Chinese obtained an influential position in Laos and, by the same token, a risky liability in Southeast Asia. For the specter that the United States might commit its ground forces or its allied troops to Laos increasingly disturbed the Chinese in 1966. A typical example is a Foreign Ministry statement issued in July:

At the instigation of the United States, military personnel of Thailand and South Vietnam have successively infiltrated into the areas of Central and Lower Laos, and the U.S. Government is making active preparations for sending its ground forces into Laos. All this shows that U.S. imperialism is plotting to extend its war of aggression against Vietnam to Laos and to the whole of Indo-China. ${ }^{106}$ 
Evidently the Chinese sense of frustration and ineptitude at this period reflected in addition their concern over a series of diplomatic setbacks and the intensification of the Vietnam war. Whereas the Chinese argued that the U.S. was weakening itself by strategic overextension and dispersal, they saw at the same time that the U.S. power had been extended very close to their own boundaries. Indeed, they clamored against the recent U.S. policy shift in "counter-revolutionary global strategy" from Europe to Asia with its concomitant concentration of forces and bases around mainland China. Moreover, the Chinese regarded this as a development of an anti-Peking "unholy alliance" forged among imperialists, revisionists, and reactionaries of the world; they argued that Moscow's policy of détente in Europe and in nuclear fields made such a U.S. strategic shift possible. ${ }^{107}$ This "unholy alliance" seemed to generate an increasing feeling of encirclement and isolation among the Chinese leaders.

When the British Government again unilaterally published in August, 1966, a 700-page majority report prepared by Indian and Canadian members of the International Commission concerning its investigation of North Vietnamese military intervention in Laos, the Chinese assailed it as "illegal," blaming both the Commission and the Geneva Co-chairmen. In a letter to Phoumi Vongvichit, Chen Yi said that the British Government and the Commission had renewed their slanders against the Democratic Republic of Vietnam and the Neo Lao Haksat "for the purpose of deluding world opinion and serving U.S. imperialism's scheme of expanding its war of aggression." 108 Even though the Soviet Government opposed the Commission's investigation and report, the Chinese nonetheless seized this opportunity to make their first public accusation against Moscow's role in Laos. As the Geneva Co-chairmen, Chen Yi said, the British and Soviet governments had consistently connived at the Commission's illegal activities and thus had fully proved themselves "accomplices of U.S. imperialist aggression." By this charge Chen Yi undoubtedly intended to provide Phoumi Vongvichit with additional grounds for suspicion toward the Soviet Union; the NLH leaders were already dissatisfied with the 15-day state visit which King Savang Vattana and Premier Souvanna Phouma had paid to Moscow in May, 1966, on the invitation of President Podgorny of the Supreme Soviet Presidium. 
In the wake of its published report on Laos, Phoumi Vongvichit categorically declared that the Commission had forfeited its legal basis for operation since July, 1965. Although the Chinese supported his opposition against the Commission's "illegal" activities, they still recognized its potential usefulness and thus simply asked the Geneva Cochairmen to initiate discussions about the question of the Commission's legal status. Chairman G. L. Puri of the Commission told me that the Commission had the legal right to continue its functions unless its members unanimously agreed to terminate them. In 1967, the NLH modified Phoumi Vongvichit's categorical position and Soth Phetrasi took a more flexible attitude closer to the Chinese position. ${ }^{109}$

Not only the United States and Great Britain but also the Soviet Union held a common view that the present Commission should be preserved as the only available machinery that might stabilize the worsening situation in Laos. In a message to the Commission in early September, 1966, the Soviet Government refuted the Commission's majority report, but suggested that "the International Commission must perform its functions in strict accordance with the Geneva agreements." Unlike the bitter statements of Phoumi Vongvichit and Chen Yi, the Soviet message neither assailed the Commission as a tool of the U.S. aggression nor raised any issue about its legal status. ${ }^{110}$

In addition to the critical repercussions of the ever-enlarging war in Vietnam throughout 1966 and 1967, the Chinese People's Republic confronted a serious domestic crisis in the violent "Great Proletarian Cultural Revolution." Although it is too early to assess its full effects, this domestic political convulsion did affect China's approach toward Laos in certain respects. At the time of the Revolution the Chinese Embassy in Vientiane erected on its compound a large red monument with a quotation from Mao Tse-tung's teachings in Chinese and in Lao: "The people, and the people alone, are the motive force in the making of world history." 111 This monument symbolized China's conscious effort to demonstrate the significance of the Revolution and to carry on an international campaign glorifying Mao's political and revolutionary ideals. The Chinese translated into Lao a little red book, Quotations from Chairman Mao Tse-tung, and his "three most often quoted articles"-namely, "Serve the People" (September, 1944), "In Memory of Norman Bethune" (December, 1939), and "The Foolish Old Man 
Who Removed the Mountain" (June, 1945). They distributed these translated materials in the "liberated areas" through such channels as the Economic and Cultural Mission at Khang Khay, the ConsulateGeneral at Phong Saly, and a number of Overseas Chinese schools. ${ }^{112}$ And the Chinese Cultural Service Center in Vientiane freely handed out all kinds of works of Mao, written in Chinese, Lao, French, Thai, and English.

Evidently the Chinese Cultural Revolution received considerable support from some elements of the NLH and the Laotian People's Liberation Army, especially from the second-echelon young cadres. In a message on October 1, 1966, Chairman Souphanouvong of the NLH Central Committee for the first time publicly praised the "great success" of the Cultural Revolution under the leadership of Chairman Mao Tsetung. ${ }^{113}$ A spokesman for the Army Supreme Command, General Singkapo Chounlamany, also said in October:

The great socialist cultural revolution being made in China is an entirely new revolution. We are glad to see that it is a struggle to purify culture and ideology, and a struggle waged under the leadership of Chairman Mao Tse-tung. Each of us has infinite faith in Chairman Mao Tse-tung. We see that Mao Tse-tung's thought is the crystallization of the truth. ${ }^{114}$

The Army's Political Department encouraged its soldiers to study Mao's writings, regularly carried Mao's quotations in its official paper Liberation Army, and translated into Lao such military works of Mao as "Problems of Strategy in China's Revolutionary War," "Problems of Strategy in Guerrilla War Against Japan," and "Problems of War and Strategy."115,

The Lao Army leaders apparently believed that Mao's concepts and tactics of the "people's war" might serve the purpose of ideological reform in an army losing its morale under increasing hardship. Indeed Singkapo called Mao's paper-tiger thesis a "weapon for the victorious struggles of the Laotian people," and added, "We take Mao Tse-tung's works as textbooks because his works reflect the spirit of people's war politically and militarily." And Nouhak Phoumsavan, a member of the Standing Committee of the NLH Central Committee, readily attributed the success of the anti-imperialist struggles in Laos to Mao's notion of the people's war. ${ }^{116}$ When Sithone Komadam (a Vice-Chairman of the NLHCC) and Sisana Sisane (a member of the NLHCC) 
visited Peking in January, 1967, Foreign Minister Chen Yi conferred with them and apparently explained the situation of the Cultural Revolution. ${ }^{117}$

As some Lao publications in Vientiane, including the Governmentoperated Lao Presse, criticized and ridiculed the Cultural Revolution and Mao Tse-tung, the Chinese Embassy in October, 1966, strongly protested to the RLG for executing and condoning anti-Peking "plots." The Chinese also complained of the frequent visits to Taiwan of some National Assemblymen, the attendance of Government Ministers at a reception held by pro-Chiang Chinese in Vientiane, and the spread of a rumor ascribing the recent Mekong River flood-the worst in a few decades-to Chinese nuclear explosions. ${ }^{118}$ Such deliberate right-wing activities, warned People's Daily (November 14, 1966), assisted the U.S. "aggressive wars" in Indo-China and its "criminal acts" on China's periphery. Similar protests were presented to Souvanna Phouma during 1967, especially in regard to the visit of a Nationalist Chinese economic delegation to Vientiane and the publication of two anti-Peking Chineselanguage newspapers in Laos. In order not to irritate Peking, Souvanna Phouma suspended these two newspapers and asked all journalists in Vientiane to avert any cause of international misunderstandings. ${ }^{119}$

During the Cultural Revolution the Chinese assumed a militant, predominantly ideological line in their declarations toward Laos. For example, in a message to Supreme Commander Khamtay Siphandone of the Laotian People's Liberation Army in January, 1967, Defense Minister Lin Piao said that the glorious victory of the Laotian people in their anti-imperialist struggle verified the wisdom of Mao Tse-tung's paper-tiger thesis on imperialism. He promised the "total support" of the Chinese people and Army to the Laotian people until the U.S. aggressors were completely defeated..$^{120}$ But the Chinese were much less radical in Laos than in the latter country's two neutral neighbors, Burma and Cambodia. They appeared to be less creative and responsive in Laos and more inward-looking and self-centered. I found that unlike Soviet and Pathet Lao representatives, Chinese diplomats in Vientiane were extremely cautious and reluctant to talk with foreign visitors. ${ }^{121}$ Preoccupied with such urgent domestic problems as political rearrangement, military modernization, and economic reconstruction, the CPR indeed failed not only to initiate any major step toward re- 


\section{solving the persistent conflict in Laos, but also to show any favorable response to a series of proposals for negotiations on Laos and Vietnam.}

\section{Notes}

1. Yin-tu-chih-na-wen-t'i-wen-chien-hui-pien, Volume IV [Collected Documents Concerning Problems in Indo-China] (Peking: 1964, hereinafter referred to as Yin-chih-wen-chien (Vol. IV)), pp. 179-180.

2. Ibid., pp. 181-184.

3. People's Daily, April 26, 1961.

4. Peking Review, July 27, 1962, p. 20.

5. See People's Daily (September 8, 1962); on August 17, Liu Ch'un visited Souvanna Phouma and Quinim Pholsena and undoubtedly asked them to adopt a more radical step to remove Hang from Laos, ibid., August 18, 1962.

6. Before the King visited Peking, China's 17 "people's organizations" formed the ChineseLaotian Friendship Association; it was headed by Lien Kuan, who was also Vice-President of the Chinese People's Institute for Foreign Affairs and Deputy Secretary-General of the Standing Committee of the National People's Congress. The Association received visitors from Laos, sponsored cultural exchanges, and also issued statements in support of the Laotian people's "just struggles." (See ibid., March 5, 1963.)

7. Yin-chih-wen-chien (Vol. IV), pp. 193-196.

8. He said that 3,500 Thai soldiers, paramilitary personnel of the South Vietnamese 77th battalion, and 50 Japanese military technicians remained in Laos, ibid., pp. 197-199.

9. Lincoln White's statement in Christian Science Monitor, October 17, 1962.

10. News Release (Washington: REL), September 25, 1963.

11. Yin-chih-wen-chien (Vol. IV), pp. 199-200.

12. News Release, February 21, 1963.

13. "Problems of War and Strategy," Selected Works of Mao Tse-tung, Volume II (Peking: FLP, 1965), p. 224.

14. See, for an example of Chinese charges, People's Daily, January 20, 1963.

15. Also see ibid., March 4, 1963.

16. On April 1, Quinim Pholsena, on his way from King Savang Vatthana's reception, was assassinated by a 19-year old corporal. It was a part of several political assassinations in early 1963.

17. Peking Review (April 19, 1963), pp. 13-14.

18. Asian Recorder (July 23-29, 1963), p. 5323.

19. Peking Review (May 24, 1963), p. 12; on May 5, a similar statement was signed by Liu and Sihanouk, ibid., May 10, 1963, p. 11.

20. At the bilateral talks with Souvanna Phouma in Khang Khay on May 2-4, Souphanouvong demanded: punishment of Quinim Pholsena's murderers; creation of a unified police force in Vientiane; restoration of the rule of unanimity in the National Union Government; and formation of a Neutralist Commission composed of representatives of Kong Le and Deuane. Souvanna Phouma called these demands "unacceptable conditions," but questions to be discussed at the talks. See Yin-chih-wen-chien (Vol. IV), pp. 267-268.

21. Denis Warner, "Experiment in Neutrality: Laos Since the Geneva Agreement," New Republic (February 2, 1963), p. 14.

22. Yin-chih-wen-chien (Vol. IV), pp. 292-293; the Chinese also said that Dean Rusk's talks with Nehru in New Delhi on May 2-4, 1963, led to the dispatch of the Commission's team to the Plain of Jars.

23. People's Daily editorial, June 16, 1963.

24. U.S. House of Representatives, International Commission for Supervision and Control in Laos: Hearings Before the Subcommittee on the Far East and the Pacific of the Committee on Foreign Affairs (Washington: USGPO, 1964), pp. 11-12.

25. Ibid., p. 3.

26. News Release, July 17 and September 25, 1963.

27. People's Daily, September 10, 1963; Stuart Simmonds says that the NLH planned the incident as a "last attempt" to prevent Souvanna Phouma's planned departure for the U.N., "Laos: A Renewal of Crisis," Asian Survey (January, 1964), pp. 680-685.

28. Hsinhua News, October 15, 1963.

29. New York Times, October 30, 1963.

30. Peking Review (October 25, 1963), p. 5.

31. See People's Daily, November 15, 1963, and Peking Review (November 22, 1963), p. 5. 
32. See Tonan Ajia Yoran [Almanac on Southeast Asia] (Tokyo: 1964), p. 143.

33. See Yin-chih-wen-chien, Volume V (Peking: 1965), pp. 379-380.

34. Ibid., pp. 380-382.

35. Peking Review (April 10, 1964), p. 4.

36. Ibid., pp. 10-11.

37. The Standing Committee of the NLH Central Committee included Souphanouvong (Chairman), Sithone Komadam (Vice-Chairman), Kaysone Phoumvihan (Vice-Chairman), Phaydang (or Faydang, Vice-Chairman), Phoumi Vongvichit (Secretary-General), Nouhak Phoumsavan, Khamtay Siphandone, Phoun Sipraseut, Sisomphon, Nhia Veu, and Kham Moun.

38. Ibid., May 1, 1964, pp. 20-22.

39. See Chen Yi's reply of May 26, to the British request of May 19, ibid., May 29, 1964, pp. 6-7.

40. Parke Fulham, "New Line-Up in Laos," Far Eastern Economic Review (June 4, 1964), pp. 497-498. $22-23$.

41. Pravda (June 20, 1964), in Current Digest of the Soviet Press (July 15, 1964), pp.

42. Peking Review (May 22, 1964), pp. 3-4.

43. Ibid., May 29, 1964, pp. 5-7.

44. Los Angeles Times, May 26, 1964.

45. See the CPR statement of June 13, and Chen Yi's June 13 letters to the Co-chairmen, Peking Review (June 19, 1964), pp. 7-10.

46. "Why Laos Is Critically Important," Department of State Bulletin (July 6, 1964), p. 5.

47. See People's Daily, June 5 and July 5, 1964.

48. See ibid., June 10 and August 3, 1964.

49. Also see Peking Review (June 19, 1964), p. 8.

50. Pravda (July 27, 1964), in Current Digest of the Soviet Press (August 19, 1964), p. 23.

51. As reported in China Quarterly (October-December, 1964), p. 184.

52. Peking Review (August 7, 1964), p. 22.

53. At the end of May, 1964, Souvanna Phouma reorganized his government; he kept the four NLH posts intact, but removed the "progressive neutralist" Ministers from the cabinet.

54. For a report from Vientiane and a comment on it, see People's Daily, July 6, 1964.

55. Ibid.

56. The CPR statement of May 26, 1964, in Peking Review (May 29, 1964), p. 5.

57. The Struggle for Proletarian Leadership in the Period of the New-Democratic Revolution in China (Peking: FLP, 1962), pp. 9-14.

58. Department of State Bulletin (August 24, 1964), pp. 261-263; and see the statements of Dean Rusk and Robert S. McNamara at the Senate, Southeast Asia Resolution: Joint Hearing Before the Committee on Foreign Relations and the Committee on Armed Services (Washington: USGPO, 1966), pp. 4-9. $5-7$

59. See Peking Review, August 7 (Special Supplement), pp. ii-iii, and August 14, 1964, pp.

60. Ibid.

61. His October 8, 1964, press conference, Peking Review (October 16, 1964), pp. 10-13.

62. See People's Daily, December 16, 1963, and Hsinhua News, November 27, 1963.

63. Peking Review (October 16, 1964), pp. 10-13.

64. The CPR statement of October 16, ibid. (Special Supplement).

65. His October 19, 1964, message, ibid. (October 30, 1964), pp. 8-9.

66. Ibid., October 23, 1964, pp. 10-11.

67. "Premier Chou En-lai's Report on the Work of the Government to the First Session of the Third National People's Congress of the People's Republic of China: Summary," in Main Documents of the First Session of the Third National People's Congress of the People's Republic of China (Peking: FLP, 1965), pp. 42-43.

68. New York Times, January 17, 1965.

69. Yin-chih-wen-chien (Vol. V), pp. 507-508.

70. Lu Ting-yi, alternate member of the Political Bureau of the Chinese Communist Party Central Committee and Vice-Premier, led the Chinese delegation to Hanoi. The Phnom Penh Conference was attended by 38 Communist and neutralist organizations from Indochinese states, including the NLH, the Laotian Party of Peace and Neutrality, the Laotian Patriotic Buddhist Association, the Laotian Intellectuals and Youth Association, and the Laotian Patriotic Neutralist Forces.

71. Peking Review (March 5, 1965), p. 4.

72. See Yin-chih-wen-chien (Vol. V), pp. 619-629, and Jean Lacouture, Vietnam: Between Two Truces (New York: Random House, 1966), pp. 237-238.

73. For both statements, see Peking Review (April 2, 1965), pp. 10-11, 15-20. 
74. See Against U.S. Aggression: Main Documents of the National Assembly of the D.R.V., 3rd Legislature-2nd Session (Hanoi: Foreign Languages Publishing House, 1965), pp. 66-69.

75. See Memorandum du Neo Lao Haksat à l'Occasion du $3^{e}$ Anniversaire de la Signature des Accords de Genève de 1962 sur le Laos (n.p.: Le Comité Central du Neo Lao Haksat, 1965); and see Chen Yi's July 28, 1965, letter to Souphanouvong, Peking Review (August 6, 1965), p. 21.

76. Message No. 35 of 16 September 1965 from the International Commission for Supervision and Control in Laos to the Co-Chairmen of the Geneva Conference (n.p.: n.d.), pp. 1113.

77. The election result was as follows: Sisouk Na Champassak's "Young Turks" won 12 seats; the supporters of Souvanna Phouma, 12; Vice-Premier Leuam Insisiengmay's southern right-wing group, 15; Phoui Sananikone's group, 9; and independents, 11. See Los Angeles Times (July 21, 1965); Arthur J. Dommen, "Laos: Neutrality Comes in Many Colors," ibid. (August 1, 1965); and New York Times (July 19 and 30,1965).

78. The complete Chinese text, in People's Daily (October 27, 1965).

79. See the CPPCC statement (People's Daily, November 9, 1965), and Souphanouvong's reply on November 23 to Chou En-lai (ibid., November 27, 1965).

80. For a change of Chinese position on Vietnam, see Chae-Jin Lee, "Some Chinese Communist Attitudes Toward the Vietnam War," Vietnam Perspectives (February, 1967), pp. 3-14; the number of U.S. military personnel in South Vietnam tripled from 50,000 in June, to 150,000 in October, 1965.

81. It was estimated in December, 1965, that North Vietnam was sending through the trails about 4,500 men and 2,500 tons of supplies for each month. See Asahi Shimbun (Tokyo), December 4 and 19, 1965, and New York Times, December 18, 1965.

82. Pike, Viet Cong: The Organization and Techniques of the National Liberation Front of South Vietnam (Cambridge: MIT Press, 1966), p. 212.

83. See Harold Munthe-Kass, "Crossing the Border," Far Eastern Economic Review (July 14, 1966), p. 51, and New York Times, August 12, 1966.

84. Hsinhua News (January 21, 1966).

85. Ibid., January 20, 1966.

86. Ibid., February 6, 1966.

87. Peking Review, February 25 (p. 4) and April 1 (p. 17), 1966.

88. For analysis of political and military crisis in Laos during 1966, see Arthur J. Dommen, "Laos: The Troubled 'Neutral,'" Asian Survey (January, 1967), pp. 74-80.

89. Hsinhua News (February 15, 1966).

90. Akahata [Red Flag] (Tokyo: Japan Communist Party), October 30, 1966.

91. See Francois Nivolon, "Phouma On Tour," Far Eastern Economic Review (September 26, 1963), pp. 779-781.

92. For the French text, see Foreign Affairs Bulletin (Bangkok: Ministry of Foreign Affairs, February-March, 1966), pp. 434-436. Thailand promised to donate 1,000 MT of rice to Laos and contribute $\$ 1$ million in cement for construction of the multi-purpose Nam Ngum Dam in Laos.

93. Asahi Shimbun, November 7, 1967.

94. The amount was much smaller than Cambodia's contribution of $\$ 3$ million, South Vietnam's of $\$ 12$ million, and Thailand's of $\$ 20$ million.

95. For survey of Laos' political development during 1967, see Paul F. Langer, "Laos: Search for Peace in the Midst of War," Asian Survey (January, 1968), pp. 80-86.

96. U.S. House Committee on Foreign Affairs, Foreign Assistance Act of 1966: Hearings, Part I (Washington: USGPO, 1966), p. 186.

97. See Clark Joel, "The Foreign Exchange Operations Fund for Laos: An Interesting Experiment In Monetary Stabilization," Asian Survey (March, 1966), pp. 134-149.

98. See the Sino-Laotian joint statement of December 4, 1962, in Yin-chih-wen-chien (Vol. IV), pp. 200-202.

99. My judgment here is based on the interviews which I had with U.S. officials and Lao leaders in Vientiane during October, 1967, and on a number of scattered reports concerning Chinese activities in northern Laos. In the early 1960's, the Soviet Union agreed to construct a 150-200 bed hospital, a 50-kilowatt radio station, and a hydroelectric station for Laos. Work on these projects has not begun. The Soviet Union also provided Laos with 9 aircraft and 1 helicopter, but these are no longer operational.

100. In recent years, however, China invited political and cultural delegations only from the "liberated areas": the Joint Friendship Delegation of the NLH and the neutralists headed by Sithone Komadam and Gen. Phoun Sipraseuth, the youth delegation led by Sithon Sorankhoune, the Buddhist delegation, and the 51-member NLH art troupe in 1964; the Honorary Chairman of the Laotian Buddhist Association in 1965; the journalist delegation, the NLH 
cultural association delegation, and the NLH song and art troupe in 1966; Sithone Komadam, Sisana Sisane, and other NLH leaders in 1967.

101. New York Times, February 20 and July 26, 1966; there were 140,000 refugees in Laos who required total or partial subsistence assistance, and the number increased to 250,000 in 1965, Senate Committee on the Judiciary, Refugee Problems in South Vietnam and Laos: Hearings Before the Subcommittee to Investigate Problems Connected with Refugees and Escapees of the Committee on the Judiciary (Washington: USGPO, 1965), pp. 6-7.

102. My interview with Soth Phetrasi took place on October 21, 1967, at his Vientiane office which was guarded by about 100 Pathet Lao forces. Souvanna Phouma's claim was made on April 1, 1967, to Australian journalists.

103. See Tonan Ajia Yoran [Almanac on Southeast Asia] (Tokyo: 1968), p. 188.

104. Japanese Foreign Ministry (ed.), The Kingdom of Laos (Tokyo, 1966), p. 34; Asahi Shimbun (December 4, 1965) reported that China had sent one anti-aircraft artillery battalion and one engineer corps to Nam Tha and Muong Sing areas; and the Royal Laotian Army Supreme Command said on August 26, 1966, that China's minority forces had entered Laos and replaced North Vietnamese forces in Luang Prabang province.

105. People's Daily, August 21, 1966.

106. Peking Review (July 8, 1966), p. 40.

107. For these strategic discussions, see People's Daily editorials, January 1, April 6, and April 21, 1966.

108. Ibid., October 4, 1966.

109. My interviews with G. L. Puri and Soth Phetrasi on October 21, 1967. Also see Phoumi Vongvichit's letter of August 29, 1966, to Chen Yi in People's Daily (October 4, 1966) and 12 Années d'Intervention et d'Agression des Impérialistes Americains au Laos (n.p.: Editions du Neo Lao Haksat, 1966).

110. Pravda (September 9, 1966), in Current Digest of the Soviet Press (September 28, 1966), p. 17.

111. Quoted from “On Coalition Government" (April, 1945), Selected Works of Mao Tsetung, Volume III, p. 257.

112. For examples, see People's Daily, January 13 and 21, 1967.

113. Ibid., October 6, 1966.

114. Peking Review (October 7, 1966), p. 33.

115. Ibid., March 10, 1967, p. 29.

116. People's Daily, January 21, 1967.

117. Ibid., January 31, 1967.

118. Ibid., October 14, 1966.

119. See Hsing-tao Evening News (Hong Kong), August 26, 1967, and Hsing-tao Daily (Hong Kong), August 27, 1967.

120. People's Daily, January 21, 1967.

121. In spite of several serious attempts, I failed to carry on any meaningful conversation with Chinese diplomats in Vientiane, who simply repeated the CPR's well-known arguments. Ambassador Liu Ch'un left for China on January 20, 1967; since then he has not appeared on public occasions concerning Laos - such as the fourth anniversary of the Chinese-Laotian Friendship Association in March and the reception held in Peking by the Laotian Embassy in May, 1967 (see People's Daily, March 4, and May 13, 1967). Three interpretations are possible: (1) as a close associate of Liu Shao-ch'i, Liu Ch'un was also a victim of the Cultural Revolution; (2) with his rich experiences in minority politics, he became primarily engaged in directing the Thai "patriotic movement"; or (3) he was involved in the process of making a basic reassessment of China's policy toward Laos and her neighbors. 


\section{Chapter VI \\ Evaluation and Implications}

It is difficult to reconstruct an exact cause-and-effect relationship between Communist China's domestic conditions and its policies toward Laos, but some kind of close relations can be ascertained. In addition to respecting Lenin's dictum that to separate foreign policy from politics in general was wrong and unscientific, the Chinese seemed to project their experiences with domestic revolutionary politics and socialist transformation into their strategic assessment and external behavior. As we saw in this case study, such major internal events as the First Five-Year Economic Plan, the Great Leap Forward Movement, and the Great Proletarian Cultural Revolution had profound impact upon China's international positions. The usual pattern of domestic-external linkages is known to be either symmetrical or asymmetrical; nevertheless, our study shows that there were a variety of complex situations which did not neatly conform with either of these simplistic explanations.

Specific events within Laos, for example, necessitated a policy adjustment on China's part-often irrespective of its general internal politics and revolutionary strategy. A Chinese response was thus required by a challenge or an opportunity arising from various political conditions in Laos. These included armed conflicts, negotiated settlements, cabinet crises, national elections, a coup d'état, and Vientiane's changing attitudes toward the Pathet Lao and Communist countries. For instance, China's “militancy" shown in Laos during 1959 was attributable more to the ascendancy of Phoui Sananikone's anti-Communist initiatives than to the broad trend of China's extreme domestic mood and its rigid external posture. Of particular importance to China were the extent of foreign interference in Laos and the relative roles of the Geneva Co-chairmen, the International Control Commission, the United Nations, and SEATO.

When the process of their policy adjustment toward Laos proved ineffective or counterproductive, the Chinese often appeared confused and indecisive. At such times they failed to take any reasonable initiative or response with regard to Laos' crisis. Sometimes they were com- 
placent about the status quo or unable to do anything positive about Laos. Again they were sometimes preoccupied with other priority issues or anxious to avoid an impression of their overt interference in the domestic affairs of Laos. After the beginning of a civil war in late 1960, and particularly after the opening of the second Geneva Conference, however, they actively sought to assume a leading role in every major political event in Laos.

The development of Sino-Laotian relations was also greatly affected by the form of Sino-Soviet competition and by the role Hanoi played in Laos. In spite of calling in identical languages for support of the Pathet Lao's national liberation or for struggle against the U.S., both China and Russia demonstrated substantial differences in their conceptions of and responses to Laos' situations. In a subtle but serious quest to influence the Pathet Lao's strategy and tactics, the Chinese enjoyed and exploited their geographic, historical, and ideological advantages over the Soviets. The strategists both in Peking and in Moscow could make an assessment or a decision concerning Laos only after having carefully considered possible countermoves by the other country. Once in a while the Soviet Union assumed an assertive role in the Pathet Lao movement and solicited Hanoi's cooperation to that end, as they did in late 1960 .

As a Co-chairman of the Geneva Conferences the Soviet Union took on a special obligation to see that the agreements were respected and followed by all parties. But the dilemma inherent in Moscow's dual responsibilities-to keep peace and order in Laos as Co-chairman and to assist the Pathet Lao's liberation movement as a Communist powerwas used by China in such a way as to drive Moscow into an embarrassing position. Whenever the U.S. intensified its military maneuvers in Laos, and the Soviet Union showed an ambiguous reaction thereto, the Pathet Lao leaders tended to move closer to the Chinese camp. We must note the similarity of the Pathet Lao's policy to Peking's and the correspondence between the former's strategic outlook and the latter's policy shifts since the Gulf of Tonkin crisis of 1964. The conflict of national interests between China and Russia did not always keep them from working together or from assisting each other when each found an immediate common interest, as, for instance, cooperating to secure Laos' neutrality at the two Geneva Conferences. 
But North Vietnam was of course more directly involved than either Peking or Moscow in the entire history of the Pathet Lao's political and military operations, and thus held a stronger tactical influence over Laotian revolutionary circumstances. In fact, the origin and survival of the Pathet Lao movement were based on Ho Chi Minh's inspiration and assistance. Although both Hanoi and Peking revealed potentially significant differences in their regional aspirations and diplomatic approaches toward Laos, they were remarkably successful at collaborating in their united struggles against the U.S. presence in Indo-China, but they acted in different ways most appropriate and characteristic to each. Faced with the threat of formidable U.S. military power, however, the Pathet Lao leaders appeared to be realistically attracted by China's growing strategic capabilities and militant commitments on their behalf.

As the second Geneva formula for Laos' neutrality and coalition proved an irrevocable failure in recent years, the Chinese made a basic reappraisal of Laotian problems in the broad context of U.S. "imperialism" and Soviet "revisionism." In close cooperation with the Pathet Lao and North Vietnam, they initially tried to restore the elements of the 1962 Geneva agreements in Laos, but continued their determined struggle against the rising anti-Communist movements within and without Laos. First, they exerted verbal and diplomatic pressure on the Royal Laotian Government and the United States in an attempt to check the untoward turn of events in Laos. They then promoted a campaign for convening unconditionally another Geneva-type of conference to reaffirm the 1962 accords.

In the wake of the 1964 Gulf of Tonkin crisis, however, the Chinese shifted their policy emphasis from proposals for a negotiated settlement in Laos to more assertive "tit-for-tat" tactics against the U.S. military buildup in Indo-China. Increasingly apprehensive of further extension of the U.S. military efforts from Vietnam to Laos, they voiced their determination to resist such an American move, which would directly threaten their national security and other interests in Laos. They also helped mobilize a region-wide united front against the U.S. and its allies and reiterated their public pledge to support all revolutionary movements in driving the U.S. out of Indo-China and the whole of Southeast Asia. 
But the Chinese did not encourage the Pathet Lao leaders to attempt an outright military conquest of Laos presumably because neither the Chinese nor the North Vietnamese were prepared to meet the probable massive intervention of U.S. ground forces in Laos. It is therefore conceivable that the Pathet Lao's restrained armed activities in recent years were mainly designed to protect the "liberated areas," including the "Ho Chi Minh trails," and to obtain a military upper hand which they wished to use as an effective means of achieving limited political objectives-such as a restoration of the 1962 Geneva formula and a concomitant settlement for Indo-China. Since the prospect for another negotiated settlement in Laos was closely interwoven with overall political developments in Indo-China, especially the Vietnam war, the Chinese did not expect to see any durable solution in Laos which was not an integral part of the region-wide accommodation. In the meantime, they emphasized the necessity of the Pathet Lao's limited military operations to win a favorable position against the Royal Laotian Government.

According to our case study, there were no clear evidences which could support the contention that China's policy toward Laos was inherently "aggressive" and "expansionist." But the general pattern of China's strategies and tactics toward Laos during 1954-67 seemed to be more rational and prudent than irrational and reckless. This comparative rationality of China's policy manifested itself in various dimensions -the realistic recognition of basically limited power, the reasonable compromise between desired goals and available means, the avoidance of excessive risks and costs, and frequent policy adjustment. No doubt there were certain types of problems and situations in which the Chinese exhibited signs of irresponsible behavior. They expressed in unlimited ways their hatred and vituperation against U.S. "imperialists" and Lao "reactionaries." When their national security was threatened, their diplomatic prestige undermined, or the survival of the Pathet Lao forces endangered, they did not hesitate to issue threats and warnings. Yet they carefully refrained from making a direct, specific promise for the possible use of their armed forces in Laos. On the use of threats and warnings they were rather selective perhaps because they learned that repetitive and ambiguous bluffs might make others question the credibility of China's other serious policy pronouncements.

The demonstration of China's "militancy" and "bellicosity" was not 
always irrational; it was employed mainly as a calculated instrument of obtaining a rather limited political objective in Laos. This trend was also reflected in China's negotiating tactics over Laos. The Chinese showed deeprooted ideological and historical suspicions about a negotiated solution of antagonistic contradictions. But in a realistic revolutionary framework they regarded diplomacy and negotiation with imperialists and reactionaries as one form of "struggle," a legitimate and justifiable part of dual revolutionary tactics. When they were convinced that they would win at the conference table an outcome which could not easily be realized by other means, the Chinese were apt to set aside their ideological rigidity and political militancy. In the negotiating processes over Laos they indeed displayed a willingness to make concessions even on questions of "principle" concerning the Pathet Lao's national liberation. They usually accepted something less than they originally demanded as their political realism acknowledged the principle of give-and-take in international bargaining.

Our case study suggests that the Chinese attached the highest priority to their national security interest with regard to the actual and imagined U.S. involvement in Laos. This security concern made the Chinese sober and cautious in using their military power as a means of their foreign policy toward Laos. They were evidently aware that the level of their military preparedness and economic capability was far from being modernized and that the continued deterioration in their relations with the Soviet Union might compel China, in the event of a war with the U.S. over Laos, to fight on various fronts with decisive disadvantages in the fields of aerial confrontation and nuclear weapons. There was no indication of a Chinese threat to use the nuclear bomb in pursuing their objectives in Laos or elsewhere in Indo-China.

It is probable that from domestic frustration or for political expediency the Chinese might accelerate their verbal militancy against Vientiane and Washington or might even adopt an adventuristic gesture in this sensitive area of Sino-American conflict. However, in spite of their official claim that the Cultural Revolution prepared the Chinese people well for a war against the U.S., the Chinese were generally careful not to provoke any direct military confrontation with the vastly superior strategic power of the U.S. While they continued to warn against a possible invasion of U.S. ground forces into Laos, they never spelled out 
how they would react in such a case. They simply indicated that once the Vietnam war was directly spilled over into Laos or Cambodia they might set up a "very broad front" in Southeast Asia. For all practical purposes, the Chinese are unlikely to be indifferent if their national security and other interests are imminently threatened by the total collapse of the Pathet Lao movement or by the substantial destruction of "liberated areas" as a useful buffer against approaching hostile forces. In the absence of these crucial or unexpected circumstances, the general direction of China's strategic and diplomatic approaches toward Laos is likely to remain rational and pragmatic-at least for the time being. 


\section{Selected Bibliography}

The principal sources on which this research has been based consist of Chinese Communist newspapers, periodicals, and other publications written in Chinese or in English. Jen-min-jih-pao [People's Daily: Peking, CCP's official paper] has been extensively used, and other papers like Kwang-ming-jih-pao [Bright Daily: Peking] and Ta-kung-pao [Impartial: Peking] have been consulted. Hung-ch'i [Red Flag: Peking, CCP's semimonthly theoretical journal], Shih-chieh-chih-shih [World Knowledge: Peking, a semimonthly journal on international affairs], and Hsin-hua-pan-yueh-k'an [New China Semi-monthly: Peking] have been widely used. The most important and useful sources in English are: Peking Review (Peking: a weekly magazine of Chinese news and views since March, 1958), People's China (Peking: semimonthly, 1950-1957), and Hsinhua News Agency: Daily News Release (Peking and Tokyo).

The valuable documentation on the two Geneva Conferences is available in Chinese: Chich-chueh-lao-chua-wen-t'i-ti k'uo-ta-t'i-jih-nei-wa-hui-i wen-chien-huipien [Collected Documents on the Enlarged Geneva Conference for the Settlement of the Laotian Question: Peking, 1962] and Jih-nei-wa-hui-i wen-chien-huipien [Collected Documents on the Geneva Conference: Peking, 1954]. Two series of Chinese publications are indispensable for any original research on Chinese relations to Indochinese affairs: Yin-tu-chih-na-wen-t'i wen-chien-hui-pien [Collected Documents Concerning Problems in Indochina: Peking, 1960-1965], whose five volumes cover the period from August, 1948, to March, 1965; and Chung-hua-jen-min-kung-ho-kuo-tui-wai-kuan-hsi-wen-chien-chi [Documents on Foreign Relations of the People's Republic of China: Peking, 1958-1965] whose volumes 3-10 cover the period from 1954 to 1963.

As for Laotian sources, Laos Information Bulletin (Washington: Royal Laotian Embassy, since 1958) and News Release (Washington: Royal Laotian Embassy) have been used. Lao Presse (Vientiane: Agence d'Information Télégraphique, a daily paper since 1953) has been occasionally consulted. The documentation concerning United States policy statements, including SEATO declarations, is mainly drawn from Department of State Bulletin (Washington: the official weekly record of United States foreign policy) and from The New York Times. Research has also been based on a variety of periodicals: American Journal of International Law (Washington), American Political Science Review (Washington), Asian Survey (Berkeley), China Quarterly (London), Current Digest of the Soviet Press (New York), Current History (Philadelphia), Documents on International Affairs (London), External Affairs (Ottawa), Far Eastern Economic Review (Hong Kong), Foreign Affairs (New York), Foreign Affairs Bulletin (Bangkok), France-Asie (Saigon and Tokyo), International Affairs (Moscow), Pacific Affairs (Vancouver), Survey on International Affairs (London), Vietnam Perspectives (New York), and World Politics (Princeton).

\section{Books and Documents}

Brandt, Conrad, Benjamin Schwartz, and John K. Fairbank. A Documentary History of Chinese Communism. Cambridge: Harvard University Press, 1952.

Burchett, Wilfred G. Furtive War: The United States in Vietnam and Laos. New York: International Publishers, 1963. 
Chang Ta-chün. Liao-kung-wen-t' $i$ [The Problems of Laotian Communists]. Hong Kong: tse-yu-ch'u-pan-she, 1955.

Chen Yi. "The Present International Situation and Our Foreign Policy." Hsinhua News. September 26, 1956.

- Vice-Premier Chen Yi Answers Questions Put By Correspondents. Peking: Foreign Languages Press, 1966.

- et al. Concerning the Situation in Laos. Peking: Foreign Languages Press, 1959.

Cheng, J. Chester, ed. The Politics of the Chinese Red Army. Stanford: Hoover Institution, 1966.

Chou En-lai. "The Present International Situation and China's Foreign Policy." People's China. August 16, 1955, pp. 3-8.

- Report on the Work of the Government at the First National People's Congress. Peking: Foreign Languages Press, 1954.

- et al. China and the Asian-African Conference: Documents. Peking: Foreign Languages Press, 1955.

- et al. Main Documents of the First Session of the Third National People's Congress of the People's Republic of China. Peking: Foreign Languages Press, 1965.

- et al. People of the World, Unite, For the Complete, Thorough, Total and Resolute Prohibition and Destruction of Nuclear Weapons! Peking: Foreign Languages Press, 1963.

Chukoku Jimmin Kaihogun [Chinese People's Liberation Army]. Tokyo: Asahi Shimbun, 1967.

Cole, Allan B., ed. Conflict in Indo-China and International Repercussions: A Documentary History, 1945-1955. Ithaca: Cornell University Press, 1956.

De Berval, René, et al. Kingdom of Laos: The Land of the Million Elephants and of the White Parasol. Saigon: France-Asie, 1959.

Democratic Republic of Vietnam. Against U.S. Aggression: Main Documents of the National Assembly of the D.R.V., 3rd Legislature-2nd Session. Hanoi: Foreign Languages Publishing House, 1965.

Dommen, Arthur J. Conflict in Laos: The Politics of Neutralization. New York: Praeger, 1964.

Eden, Anthony. The Memoirs of Anthony Eden: Full Circle. Boston: Houghton Mifflin Co., 1960.

Toward Peace in Indo-China. Boston: Houghton Mifflin Co., 1966.

Editorial Departments of People's Daily and Red Flag. The Origin and Development of the Differences between the Leadership of the CPSU and Ourselves. Peking: Foreign Languages Press, 1963.

Les Elections Legislatives du 24 Avril 1960. Vientiane: Editions Vieng-Kham, 1960.

Fairbank, John K., and Ssu-yu Teng. Ch'ing Administration: Three Studies. Cambridge: Harvard University Press, 1960.

Fifield, Russell H. The Diplomacy of Southeast Asia: 1945-1958. New York: Harper and Bros., 1958.

Southeast Asia in United States Policy. New York: Praeger, 1963.

Great Britain. Documents Relating to the Discussion of Korea and Indo-China at the Geneva Conference, April 27-June 15, 1954. London: Her Majesty's Stationary Office, 1954, Cmnd. 9186. 
First Interim Report of the International Commission for Supervision and Control in Laos, August 11 to December 31, 1954. London: HMSO, 1955, Cmnd. 9445.

- Fourth Interm Report of the International Commission for Supervision and Control in Laos, May 17, 1957 to May 31, 1958. London: HMSO, 1958, Cmnd. 541.

Further Documents Relating to the Discussion of Indo-China at the Geneva Conference. London: HMSO, 1954, Cmnd. 9239.

International Conference on the Settlement of the Laotian Question, Geneva, May 12, 1961-July 23, 1962. London: HMSO, 1962, Cmnd. 1828. Second Interim Report of the International Commission for Supervision and Control in Laos, January 1 to June 30, 1955. London: HMSO, 1955, Cmnd. 9630.

Third Interim Report of the International Commission for Supervision and Control in Laos, July 1, 1955 to May 16, 1957. London: HMSO, 1957, Cmnd. 314.

Halpern, A. M., and H. B. Fredman. Communist Strategy in Laos. Santa Monica: The Rand Corporation, 1960.

Halpern, Joel M. Government, Politics, and Social Structure in Laos: A Study of Tradition and Innovation. New Haven: Yale University Press, 1964. The Role of the Chinese in Lao Society. Los Angeles: University of California, 1961.

Hammer, Ellen J. The Struggle for Indochina, 1940-1955: Viet Nam and the French Experience. Stanford: Stanford University Press, 1966.

Hinton, Harold C. Communist China in World Politics. Boston: Houghton Mifflin Co., 1966.

Kahin, George McT. The Asian-African Conference: Bandung, Indonesia, April 1955. Ithaca: Cornell University Press, 1956.

-, ed. Governments and Politics of Southeast Asia. Ithaca: Cornell University Press, 1964.

Kunstadter, Peter, ed. Southeast Asian Tribes, Minorities, and Nations. Volume I. Princeton: Princeton University Press, 1967.

Lacouture, Jean. Vietnam: Between Two Truces. New York: Random House, 1966.

Lall, Arthur. How Communist China Negotiates. New York: Columbia University Press, 1968.

Le Bar, Frank M., and Adrienne Suddard, eds. Laos: Its People, Its Society, Its Culture. New Haven: Human Relations Files, Inc., 1960.

Le Boulanger, Paul. Histoire du Laos Français: Essai d'une Etude Chronologique des Principautés Laotiennes. Paris: Librairie Plon, 1931.

Li Wei-han. The Struggle for Proletarian Leadership in the Period of the New Democratic Revolution in China. Peking: Foreign Languages Press, 1962.

Lin Piao. Long Live the Victory of People's War! Peking: Foreign Languages Press, 1965.

Liu Shao-ch'i. "On Internationalism and Nationalism." Kuo-chi-chu-i-yu-min-tsuchu-i [Internationalism and Nationalism]. Hong Kong: Hsin-min-chuch'u-pan-she, 1949, pp. 7-50.

"The Political Report of the Central Committee of the Communist Party of China to the Eighth National Congress of the Party." Hsinhua News, September 16, 1956. 
Maha Silva Viravong. History of Laos. Washington: U.S. Joint Publications Research Service, 1958.

Mao Tse-tung. Selected Works of Mao Tse-tung. Volumes I-IV. Peking: Foreign Languages Press, 1961-1965.

, et al. Eighth National Congress of the Communist Party of China:

Documents. Volumes I-III. Peking: Foreign Languages Press, 1956.

Message No. 35 of 16 September 1965 from the International Commission for Supervision and Control in Laos to the Cochairmen of the Geneva Conference. N.P.: n.d.

Miller, Richard I. Dag Hammarskjold and Crisis Diplomacy. Dobbs Ferry: Oceana Publications, 1961.

Modelski, George. International Conference on the Settlement of the Laotian Question, 1961-2. Canberra: Department of International Relations, Research School of Pacific Studies, Australian National University, 1962. ed. SEATO: Six Studies. Melbourne: F. W. Cheshire, 1962.

Morgenthau, Hans J. Dilemmas of Politics. Chicago: University of Chicago Press, 1958.

Neo Lao Haksat. Douze Années d'Intervention et d'Agression des Impérialistes Americains au Laos: A l'Occasion du IVe Anniversaire de la Signature des Accords de Genève de 1962 sur le Laos. N.p.: Neo Lao Haksat, 1966.

- Memorandum du Neo Lao Haksat à l'Occasion du 3e Anniversaire de la Signature des Accords de Genève de 1962 sur le Laos. N.p.: Neo Lao Haksat, 1965.

Pike, Douglas. Viet Cong: The Organization and Techniques of the National Liberation Front of South Vietnam. Cambridge: MIT Press, 1966.

Purcell, Victor. The Chinese in Southeast Asia. London: Oxford University Press, Second Ed., 1965.

Royal Laotian Government. Application au Laos des Accords de Genève: Memorandum adressé le 13 Avril 1955 à la Commission Internationale de Surveillance et de Contrôle au Laos. Saigon: Imprimerie Française d'Outre-Mer, 1955.

Ebauche D'Une Comptabilité Nationale Lao: Comptes Economiques Provisoires pour 1964. Vientiane: Ministre du Plan et de la Cooperation, Commissariat au Plan, 1967.

Rusk, Dean. United States Outlines Program To Insure Genuine Neutrality for Laos. Washington: USGPO, 1961.

Schlesinger, Arthur M., Jr. A Thousand Days: John F. Kennedy in the White House. Boston: Houghton Mifflin Co., 1965.

Sisouk Na Champassak. Storm Over Laos: A Contemporary History. New York: Praeger, 1961.

Snow, Edgar. The Other Side of the River: Red China Today. New York: Random House, 1962.

Sorensen, Theodore C. Kennedy. New York: Bantam, 1966.

Steiner, H. Arthur. Communist China in the World Community. New York: Carnegie Endowment for International Peace, 1961.

The International Position of Communist China: Political and Ideological Directions of Foreign Policy. New York: American Institute of Pacific Relations, 1958.

Tonan Ajia Yoran [Almanac on Southeast Asia]. Tokyo: Tonan Ajia Chosakai, 1964 and 1968. 
United Nations. United Nations Security Council Official Records: Fourteenth Year, Supplement for July, August and September 1959. New York: U.N., 1960.

-United Nations Security Council Official Records: Fourteenth Year, Supplement for October, November and December 1959. New York: U.N., 1960.

. United Nations Statistical Yearbook 1968. New York: U.N., 1968.

U.S. Agency for International Development. Fact Sheet. Vientiane: USAID/ Laos, 1967.

U.S. Congress, House Committee on Foreign Affairs, International Commission for Supervision and Control in Laos: Hearings before the Subcommittee on the Far East and the Pacific of the Committee on Foreign Affairs. Washington: U.S. Government Printing Office, 1964.

-. Mutual Security Program in Laos: Hearings before the Subcommittee on the Far East and the Pacific of the Committee on Foreign Affairs. Washington: USGPO, 1958.

U.S. Congress, House Committee on Government Operations. U.S. Aid Operations in Laos: Hearings before the Foreign Operations and Monetary Affairs Subcommittee, March 11-Iune 1, 1959. Washington: USGPO, 1959.

U.S. Congress, Senate Committee on Foreign Relations. Background Information Relating to Southeast Asia and Vietnam. Washington: USGPO, 1967.

- Report on Indochina: Report of Senator Mike Mansfield on a Study Mission to Vietnam, Cambodia, Laos. Washington: USGPO, 1954.

- Southeast Asia Resolution: Joint Hearing before the Committee on Foreign Relations and the Committee on Armed Services. Washington: USGPO, 1966.

- Vietnam, Cambodia, and Laos: Report by Sen. Mike Mansfield. Washington: USGPO, 1955.

-U.S. Policy with Respect to Mainland China: Hearings before the Committee on Foreign Relations. Washington: USGPO, 1966.

U.S. Congress, Senate Commmittee on the Judiciary. Refugee Problems in South Vietnam and Laos: Hearings before the Subcommittee to Investigate Problems Connected with Refugees and Escapees of the Committee on the Judiciary. Washington: USGPO, 1965.

U.S. Department of State. American Foreign Policy, 1950-1955: Basic Documents. Vol. 1. Washington: USGPO, 1957.

- Comment by the Department of State and ICA on the Report of the House Committee on Government Operations, "United States Aid Operations in Laos." Washington: Department of State, 1959.

Watson, Francis. The Frontiers of China: A Historical Guide. New York: Praeger, 1966.

Zagoria, Donald S. The Sino-Soviet Conflict: 1956-1961. Princeton: Princeton University Press, 1962.

\section{Articles ANd Notes}

Bundy, William P. “The United States and Communist China." Department of State Bulletin. February 28, 1966, pp. 310-318.

"Canada and the International Commission in Laos." External Affairs. September, 1958, pp. 219-221. 
Chen Yu-leng. “Traditional Friendship between China and Laos." Jen-min-jihpao [People's Daily]. August 21, 1956.

Ch'en Jerome. "China's Conception of her Place in the World." Political Quarterly. July-September, 1964, pp. 260-269.

Chiu, Hungdah. "Communist China's Attitude Toward International Law." American Journal of International Law. Volume 60, 1966, pp. 245-267.

Crozier, Brian. "Peking and the Laotian Crisis: A Further Appraisal." China Quarterly. July-September, 1962, pp. 116-123.

"Peking and the Laotian Crisis: An Interim Appraisal." China Quarterly. July-September, 1961, pp. 128-137.

Czyzak, John J., and Carl F. Salans. "The International Conference on the Settlement of the Laotian Question and the Geneva Agreements of 1962." American Journal of International Law. April, 1963, pp. 300-317.

Dommen, Arthur J. "Laos: Neutrality Comes in Many Colors." Los Angeles Times. August 1,1965 .

"Laos: The Troubled 'Neutral."” Asian Survey. January, 1967, pp. 7480.

Dulles, John F. "Policy for Security and Peace." Foreign Affairs. April, 1954, pp. 353-364.

Fall, Bernard B. "The International Relations of Laos." Pacific Affairs. March, 1957, pp. 22-34.

“The Pathet Lao: A 'Liberation' Party.” In Scalapino, Robert A., ed. The Communist Revolution in Asia: Tactics, Goals, and Achievements. Englewood Cliffs: Prentice-Hall, Inc., 1965, pp. 173-197.

"Red China's Aims in South Asia." Current History. September, 1962, pp. 136-141, 181.

Fang Ming. "U.S. Intervention Must Stop." Peking Review. February 8, 1963, pp. 7-8.

Fulham, Parke. "New Line-Up in Laos.” Far Eastern Economic Review. June 4, 1964, pp. 497-498.

Gross, Leo. "The Question of Laos and Double Veto in the Security Council." American Journal of International Law. Volume 54, 1960, pp. 118-131.

Halpern, A. M. "China in the Postwar World." China Quarterly. JanuaryMarch, 1965, pp. 20-45.

Ho Cheng. "The Great Asian-African Conference." People's China. May 16, 1955, pp. 3-6.

Hung Lan. "SEATO-Instrument of U.S. Aggression." Peking Review. March 2, 1962, pp. 7-8.

Joel, Clark. "The Foreign Exchange Operations Fund for Laos: An Interesting Experiment in Monetary Stabilization." Asian Survey. March, 1966, pp. 134-149.

Langer, Paul F. "Laos: Search for Peace in the Midst of War." Asian Survey. January, 1968, pp. 80-86.

"Laos: 1960-1963." Current Notes on International Affairs. April, 1964, pp. 7-18.

Lee, Chae-Jin. "Some Chinese Communist Attitudes Toward the Vietnam War." Vietnam Perspectives. February, 1967, pp. 3-14.

McAlister, John T., Jr. "The Possibilities for Diplomacy in Southeast Asia." World Politics. January, 1967, pp. 258-305.

Munthe-Kaas, Harold. "Crossing the Border." Far Eastern Economic Review. July 14, 1966, pp. 51, 53. 
Murray, Douglas P. "Chinese Education in Southeast Asia." China Quarterly. October-December, 1964, pp. 67-95.

Nivolon, Francois. "Phouma On Tour." Far Eastern Economic Review. September 26, 1963, pp. 779-781.

Pace, Eric. "Laos: Continuing Crisis." Foreign Affairs. October, 1964, pp. 6474.

Rusk, Dean. "Why Laos Is Critically Important." Department of State Bulletin. July 6, 1964, pp. 3-6.

Simmonds, E. H. S. "Independence and Political Rivalry in Laos, 1945-61." In Rose, Saul, ed. Politics in Southern Asia. London: Macmillan Co., 1963, pp. 164-199.

"Laos: A Renewal of Crisis." Asian Survey. January, 1964, pp. 680-685.

- "Power Politics in Laos." World Today. December, 1962, pp. 514-523.

Smith, Roger. "Cambodia's Neutrality and the Laotian Crisis." Asian Survey. July, 1961, pp. 17-24.

"Laos in Perspective." Asian Survey. January, 1963, pp. 61-68.

Stanton, Edwin F. “A Presence in Laos." Current History. June, 1960, pp. 337341, 346.

Steiner, H. Arthur. "Ideology versus National Interest in Chinese Foreign Policy." In Szczepanik, E. F., ed. Symposium on Economic and Social Problems of the Far East. Hong Kong: Hong Kong University Press, 1962, pp. 246-258.

Tsou, Tang, and Morton H. Halperin. "Mao Tse-tung's Revolutionary Strategy and Peking's International Behavior." American Political Science Review. March, 1965, pp. 80-99.

Tsu Chi and Lan Pu. "The Victorious Achievement of New Geneva Agreements." Shih-chieh-chih-shih [World Knowledge]. July 25, 1962, pp. 4-6.

Warner, Denis. "Experiment in Neutrality: Laos Since the Geneva Agreement." New Republic. February 2, 1963, pp. 12-14.

Yang Ming. "The Laotian Situation after the Vientiane Military Coup." Shihchieh-chih-shih. May 10, 1964, pp. 7-8.

Yegorov, M. "The Geneva Conference on Laos." International Affairs. September, 1961, pp. 38-44.

Young, Kenneth T. "American Dealings with Peking." Foreign Affairs. October, 1966, pp. 77-87.

Yu Chao-li. "The Great Victory of the Laotian People." Hung-ch'i [Red Flag]. September 16, 1962, pp. 1-8.

"Imperialism-Source of War in Modern Times-and the Path of the People's Struggle for Peace." Hung-ch'i. April 1, 1960, pp. 1-12. 



\section{Index}

Air America, 102

Algeria, 49

Argentina, 59

Asian and Pacific Council (ASPAC), 132

Asian Development Bank, 132

Australia, 88, 133

Avtar Singh, 106, 107, 108

Bandung Spirit, 24, 27, 29

Bell, Cora, 19

Berlin Conference of Four Foreign Ministers, 14

Bhutan, 32, 99

Bidault, Georges, 16, 17, 19

Bong Souvannavong, 29

Boun Oum, 73, 74, 75, 77, 79, 80, 84, 87, 91, 98,127

Brezhnev, Leonid, 118

Brown, Winthrop G., 77

Bundy, William P., 114, 133

Burma, x, 24, 25, 52, 77, 81, 140

Butler, R. A., 118

Cambodia, x, 13, 15, 16, 17, 19, 20, 22, 23, $25,45,74,77,87,94,115,122,125,140$ Camp David Talk, 62

Canada, 18, 45, 85, 106, 107, 116, 117, 126, 136

Central Intelligence Agency, 102

Chang Han-fu, 84, 86, 87

Chauvel, Jean, 83

Chen Yi, 31, 49, 60, 63, 74, 75, 78, 81, 82, 83, $84,86,91,97,98,105,115,121,125,128$, $136,137,138,140$

Chiang Kai-shek, 99, 110, 140

Chinese Consulate-General, 139

Chinese Cultural Service Center, 139

Chinese Economic and Cultural Mission, 139

Chinese People's Peace Committee, 63

Chinese People's Political Consultative Conference, 128

Chiu, Hungdah, 59

Chou En-lai, 6, 16, 17, 18, 19, 21, 22, 25, 26, $27,31,32,34,39,47,67,68,72,79,80$, $93,94,98,104,112,123,124,125$

Coalition Government, 24, 53, 68, 73, 88, 89, 90, 101, 118

Committee for the Defense of National Interest (CDNI), 45, 47, 65, 67

Committee for the Maintenance of a Peaceful Neutral Policy, 29

Communist Party of the Soviet Union, 8, 44

Coup d'état in Laos, 65, 69, 72, 103, 113, 114, 145

de Gaulle, Charles, 115

de Murville, Couve, 80

Deuane Siphaseuth, 103, 112

Dien Bien Phu, 15

Domino Theory, 22

Dulles, John F., 14, 15, 16, 21, 22, 23, 24, 31, 39
Eden, Anthony, 14, 17, 19, 22, 40n

Eisenhower, Dwight, 22, 36, 62, 76

Elections in Laos, 20, 28, 29, 42, 43, 44, 47, $48,65,66,67,68,127,145$

Fa Ngoum, 4

Faydang, 54

Felt, Harry D., 50

First Five-Year Economic Plan, 21

Five Principles of Peaceful Coexistence, 21

France, ix, 13, 15, 17, 18, 22, 23, 24, 49, 55, $58,59,83,84,86,90,91,107,132$

Franco-Siamese Treaty of 1893 , ix

French Union, ix, 13

General Franco-Laotian Convention of 1949, ix

Great Britain, 14, 15, 17, 57, 58, 59, 75, 76, $78,79,88,90,100,107,111,113,114,116$, $117,124,126,136,138$

Great Leap Forward Movement, 42, 145

Great Proletarian Cultural Revolution, 3, 128, $138,139,140,145$

Gromyko, Andrei, 57, 63, 84, 85, 87, 91

Gross, Leo, 59

Halpern, Joel, vii

Hammarskjold, Dag, 47, 58, 64, 65, 69, 105

Hang Li-wu, 46, 99

Hanoi-Vientiane Agreement of 1955, 26

Harriman, W. Averell, 83, 84, 86, 87, 89

Heurtematte, Roberto, 64

Hilsman, Roger, 108

Ho Chi Minh, ix, 13, 16, 19, 20, 43, 62, 80, 105,147

Ho Chi Minh Trail, 124, 128, 135, 148

Ho Wei, 98

Holt, Harold, 133

Home, Alex Douglas, 80, 87, 108

Humphrey, Hubert H., 132

India, 18, 25, 27, 40n, 45, 50, 53, 60, 63, 69, $75,79,82,84,85,90,97,106,107,116$, $117,126,136$

Indochinese Communist Party, 13, 131

Indochinese People's Conference of 1965, 125

Indonesia, 97

Infantile Adventurism, 8

International Conference for Solidarity with the People of Vietnam against U.S. Imperialist Aggression and for the Defense of Peace, 125

Iraq, 47

Italy, 59

Japan, 46, 59, 131, 132, 139

Japanese Communist Party, 131

Johnson, Lyndon B., 114, 120, 122, 124, 126, 129,132

Johnson, U. Alexis, 39

Kahin, George McT., 25

Katay Don Sasorith, 24, 25, 26, 27, 28, 29, 33, $34,37,42,44,46$ 
Kaysone Phoumvihan, 24, 54, 131

Kennedy, John F., 76, 77, 78, 88, 91

Khamphan Panya, 54, 58, 59, 61

Khampheuane Tounalom, 104

Khamtay Siphandone, 54, 127, 129, 140

Khana Santiphab. See Committee for the Maintenance of a Peaceful Neutral Policy Khmer Issara, 16, 17

Khrushchev, Nikita S., 47, 57, 62, 63, 74, 91, $111,117,118,129$

Kong Le, 72, 73, 74, 76, 87, 102, 103, 105, $106,109,114$

Korean War, 20

Kosygin, Aleksei, 118

Kou Abhay, 65

Kouprasit Abhay, 113, 114, 127, 130

Kunstadter, Peter, vii

Kuomintang, 1, 24, 50, 51, 52, 57, 81, 86, 88, $91,93,100,140$

Kuo Mo-jo, 63

Lao Dong Party, 13

Lao Issara (Free Laos), ix, 13

Laotian-Chinese Friendship Highway, 119, 134

Laotian People's Party, 131

Lebanon, 47

Leuam Insisiengmay, 127

Li Wei-han, 120

Liberated Areas, 14, 93, 98, 101, 102, 107, $113,119,121,124,127,130,135,136,139$, 148

Lin Piao, 3, 129, 140

Liu Ch'un, 98, 99, 109, 110

Liu Pei-hua, $x$

Liu Shao-ch'i, 13, 31, 105

Lloyd, Selwyn, 57, 63

Locarno Agreement, 20

MacArthur, Douglas, 21

Malaysia (or Malaya), 77, 132

Manila Pact. See Southeast Asia Treaty Organization

Mansfield Michael, 28

Mao Tse-tung, 1, 2, 3, 7, 10, 31, 32, 42, 62, $63,92,102,138,139,140$

Massive Retaliation, 20, 22, 56

Mekong River Development Project, 46, 134

Mendès-France, Pierre, 17, 19

Ministerial Conference for Economic Development of Southeast Asia, 132

Modelski, George, 89

Modern Revisionism, 67, 92, 121, 122, 137, 147

Molotov, V. M., 16, 19

Mus, Paul, 19

Mutual Defense Assistance Agreement of 1950, 23

Mutual Defense Treaty of 1954, 39

Nam Ngum Development Project, 134

Nationalist China. See Kuomintang

National Liberation, 76, 92

National Liberation Front of South Vietnam, $110,112,121,124,126,128,130$

National Union Government, 101, 104, 130
National Union Party, 44

Nehru, 21, 25, 26, 29, 31, 34, 75, 79

Neo Lao Haksat, viii, 28, 30, 42, 43, 44, 45, $46,53,63,64,66,68,72,73,100,104,106$, $109,111,112,113,114,119,120,122,123$, $126,127,130,131,135,137,138,139$

New Zealand, 88

Ngo Dinh Diem, 36, 43, 46

Ngo Dinh Nhu, 46

Ngone Sananikone, 58

Nguyen Khanh, 112

Norodom Sihanouk, 20, 33, 75, 76, 77, 79, 93, $94,115,118,119,125$

Nouhak Phoumsavan, 54, 123, 139

Ouan Rathikoun, 50, 127

Oudone Sananikone, 127

Overseas Chinese, 9, 51, 52, 110, 139

Paper Tiger, 7, 136, 139, 140

Parsons, J. Graham, 34, 46, 73, 114

Peking Agreement of 1956, 42

P'eng Teh-huai, 27

People's War, 7, 139

Pham Van Dong, 16, 17, 26, 27, 34, 65, 68, 113

Pheng Phongsavan, 44

Phetsarath, ix

Philippines, 105

Phoui Sananikone, 16, 17, 28, 37, 42, 44, 45, $46,47,48,49,51,53,54,57,63,64,65$, $68,72,103,104,127,145$

Phoumi Nosavan, 47, 65, 66, 72, 73, 74, 76, $77,78,79,86,87,88,89,98,100,101,102$, $103,105,108,109,110,111,112,113,114$, $121,124,127$

Phoumi Vongvichit, 37, 54, 93, 104, 109, 111, $120,130,136,137,138$

Phoun Sipraseuth, 54

Pike, Douglas, 128

Plain of Jars, 53, 100, 103, 106, 113, 114, 115

Plain of Jars Agreement, 88

Podgorny, Nikolai, 137

Poland, 18, 45, 85, 106, 107, 117

Political Consultative Conference of the Neo Lao Haksat, 1966, 127, 130, 131

Puri, G. L., 138

Pushkin, Georgi M., 88

Quinin Pholsena, 29, 98, 99, 103, 104

Rally of the Laotian People, 44, 67

Republic of China. See Kuomintang

Revolutionary Bases, 10

Rumania, 97

Rusk, Dean, 80, 81, 82, 83, 116, 120

Russia. See Union of Soviet Socialist Republics

Sam Sen Thai, 4

Sarit Thanarat, 73

Sato Eisaku, 133

Savang Vatthana, 23, 37, 65, 77, 99, 100, 137

Security Council. See United Nations

Seventh Fleet, 75, 105

Shelepin, Alexandr, 129 
Siho Lamphoutacoul, 108, 109, 113, 127

Singkapo Chounlamany, 24, 54, 100, 139

Sino-American Ambassadorial Talks, 39, 47, 78

Sino-Indian Trade Agreement of April 1954, 21,26

Sino-Laotian Joint Statements, 6, 38, 98

Sisana Sisane, 139

Sisavang Vong, ix

Sisouk Na Champassak, 127

Sisoumang Sisaleusak, 111

Sithone Komadam, 54, 139

Smith, Horace, 65

Snow, Edgar, 94

Sobolev, A., 59

Son Ngoc Minh, 16

Soth Phetrasi, 135, 138

Souk Vongsak, 54, 104

Souphanouvong, ix, 13, 14, 24, 27, 29, 30, 36, $37,42,43,44,54,68,73,75,77,80,84$, $87,89,91,98,104,105,106,111,112,113$, $114,121,122,123,131,139$

South Korea, 50, 132

South Vietnam, x, 46, 50, 52, 53, 54, 83, 86, $87,93,94,97,105,109,112,113,116,120$, $121,122,124,125,126,128,129,131,136$

Southeast Asia Treaty Organization (SEATO), $7,22,23,25,28,32,33,35,48,50,53,57$, $58,60,75,78,81,82,86,87,88,89,90$, $91,105,145$

Souvanna Phouma, ix, 6, 29, 30, 31, 32, 33, $34,36,37,38,44,45,46,67,72,73,74$, $75,77,78,79,80,84,86,87,88,89,91$, $98,99,100,101,103,104,105,106,108$, $109,111,112,113,114,115,116,118,119$, $120,121,123,127,130,131,132,133,135$, 137,140

Soviet Union. See Union of Soviet Socialist Republics

Stanton, Edwin S., 65

Sukarno, 31

Sullivan, William H., 87, 88, 124

Taipei-Vientiane Consular Agreement of 1958, 51,98

Taiwan Straits Crisis, 47
Taylor, Maxwell D., 124

Tep Phan, 17

Thailand, ix, x, 23, 46, 48, 50, 52, 53, 54, 73, $88,93,94,97,104,105,116,122,127,129$, 136

Thanat Khoman, 54, 131

Thanom Kittikachorn, 131, 133

Thao Ma, 130

Tiao Somsanith, 68, 72

Tonkin Incident, Gulf of, 120, 121, 122, 146, 147

Tributary System, 4, 5, 6

Tseng Ho, 66, 67

Tsiang, 4

Tunisia, 59

Tuomioja, Sakari, 64, 65, 69

$\mathrm{U} \mathrm{Nu}, 21,31$

U Thant, 105

Unger, Leonard, 114

Union of Soviet Socialist Republics, $\mathrm{x}, 3,6,8$, $16,17,20,27,42,45,47,49,56,57,58$, $59,60,62,63,66,67,68,74,75,77,78,79$, $80,84,85,86,87,88,90,91,101,105$, $106,107,111,115,117,118,122,123,124$, $132,136,137,138,140,146$

United Front, 43, 72, 79, 99, 127, 128, 147

United Nations, 18, 47, 48, 57, 58, 59, 60, 61, $62,64,65,68,69,77,101,105,133,145$

United States Information Service, 102

Vientiane Agreement of $1957,42,57,60,65$, 73

Viet Minh, ix, 13, 14, 15, 16, 17, 18, 19, 20, $24,28,37,76,80,108$

Vo Nguyen Giap, 15

Wang Ping-nan, 39, 78

Warsaw Pact, 27

Washington, Genoa S., 37

Xuan Thuy, 125

Yu Chao-li, 67, 93, 103

Zellweger, Edouard, 69

Zurich Agreement of 1961, 101 